INTERNATIONAL MONETARY FUND

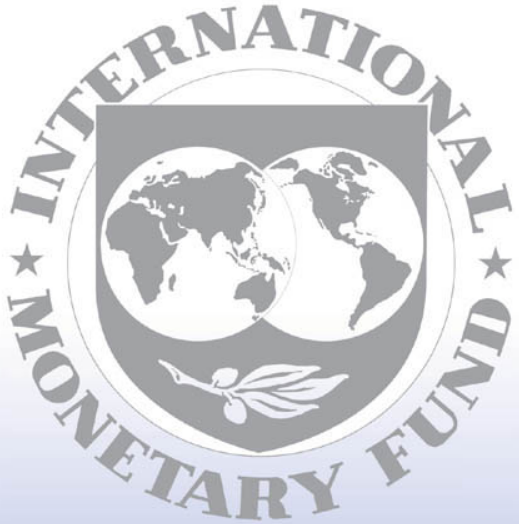

Staff

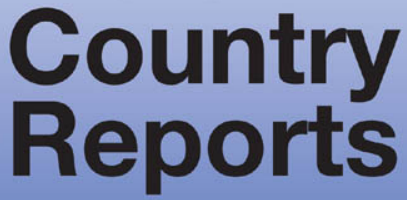




\section{Burundi: Poverty Reduction Strategy Paper-Annual Progress Report}

Poverty Reduction Strategy Papers (PRSPs) are prepared by member countries in broad consultation with stakeholders and development partners, including the staffs of the World Bank and the IMF. Updated every three years with annual progress reports, they describe the country's macroeconomic, structural, and social policies in support of growth and poverty reduction, as well as associated external financing needs and major sources of financing. This country document for Burundi, dated November 2008, is being made available on the IMF website by agreement with the member country as a service to users of the IMF website.

Copies of this report are available to the public from

International Monetary Fund • Publication Services $70019^{\text {th }}$ Street, N.W. • Washington, D.C. 20431

Telephone: (202) 623-7430 • Telefax: (202) 623-7201

E-mail: publications@imf.org • Internet: http://www.imf.org

\section{International Monetary Fund Washington, D.C.}


This page intentionally left blank 


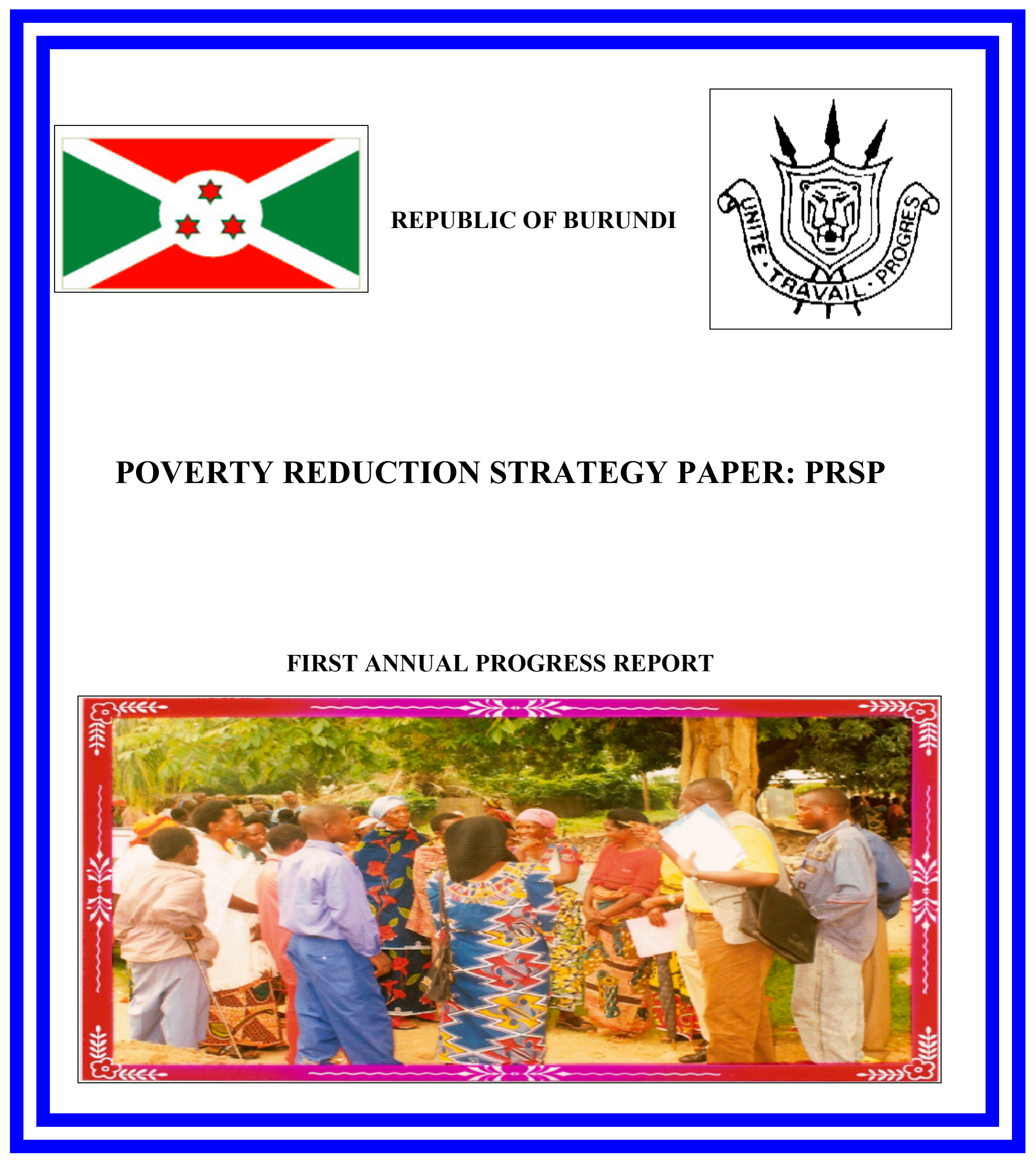




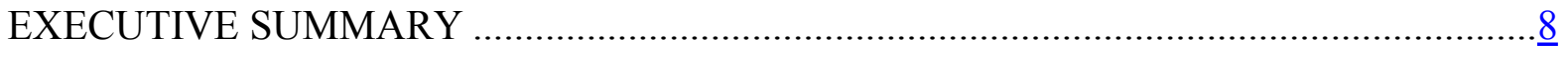

APPRAISAL FINDINGS ....................................................................................

AXIS 1: IMPROVED GOVERNANCE AND SECURITY ..................................................

AXIS 2: PROMOTION OF SUSTAINABLE AND EQUITABLE GROWTH …..........................

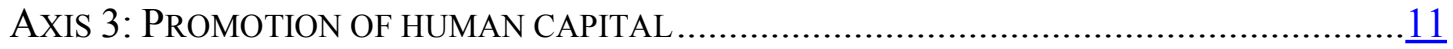

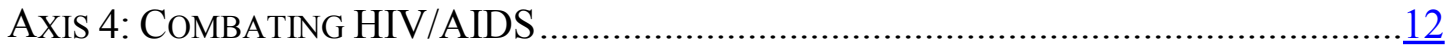

MACROECONOMIC PERFORMANCE ........................................................... $\frac{13}{14}$

MONITORING AND EVALUATION MECHANISMS .............................................. 14

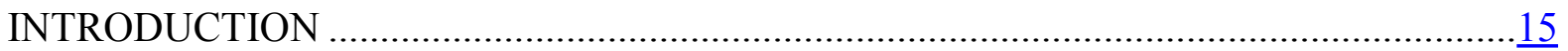

I. RECENT SOCIOPOLITICAL AND ECONOMIC DEVELOPMENTS .........................16

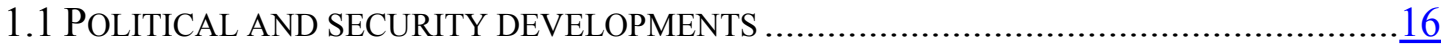

1.2 SOCIAL AND ECONOMIC DEVELOPMENTS.......................................................

1.3 PRSP MONITORING AND EVALUATION MECHANISMS ....................................... 19

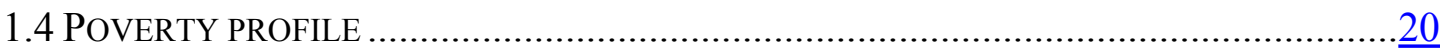

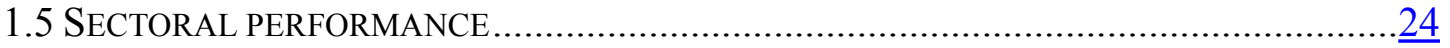

II. IMPROVING GOVERNANCE AND SECURITY …...........................................

2.1 STRENGTHENING PEACE, NATIONAL RECONCILIATION, AND SECURITY ....................

2.2 PROMOTING THE RULE OF LAW, COMBATING IMPUNITY, AND PROMOTING

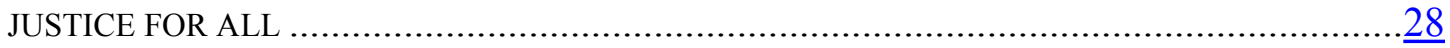

2.3 RESOLVING THE RISKS OF CONFLICTS ASSOCIATED WITH LAND TENURE /

SUSTAINABLE MANAGEMENT OF LAND TENURE CONFLICTS …...............................

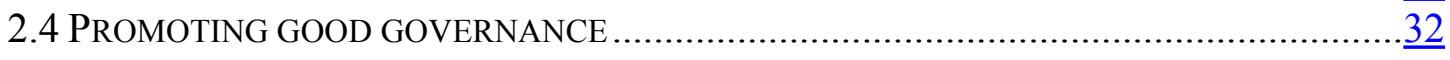

III. PROMOTION OF SUSTAINABLE AND EQUITABLE ECONOMIC GROWTH ........

3.1 REVITALIZATION OF AGRICULTURE, LIVESTOCK FARMING, FISHERIES, AND FISH

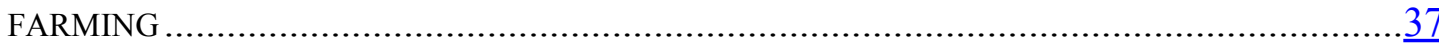

3.2 ENVIRONMENTAL PROTECTION AND IMPROVEMENT .......................................

3.3 DEVELOPMENT OF TRADE AND INDUSTRY .................................................. $\frac{47}{48}$

3.4 RATIONAL EXPLOITATION OF MINES AND QUARRIES ....................................... $\frac{48}{48}$

3.5 PROMOTION OF TOURISM AND CRAFTS ……................................................. $\frac{48}{48}$

3.6 INCREASED JOB AND INCOME-EARNING OPPORTUNITIES FOR THE POOR ….............. $\frac{48}{2}$

3.7 DEVELOPMENT OF THE PRIVATE SECTOR ......................................................

3.8 DEVELOPMENT OF INFRASTRUCTURES SUPPORTING PRODUCTION .........................

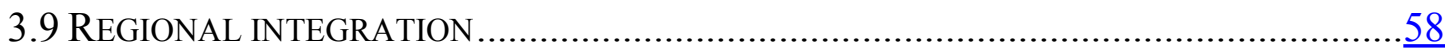

IV. DEVELOPMENT OF HUMAN CAPITAL .......................................................59

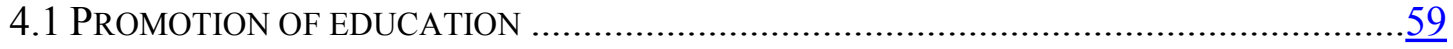

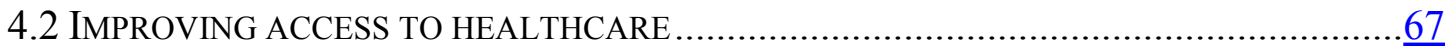




\subsection{IMPROVING ACCESS TO DRINKING WATER, HYGIENE, SANITATION AND DECENT}

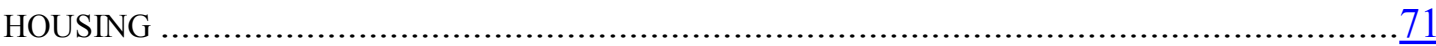

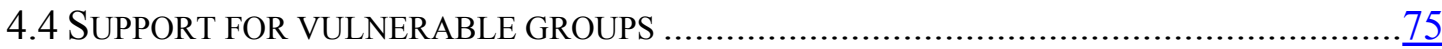

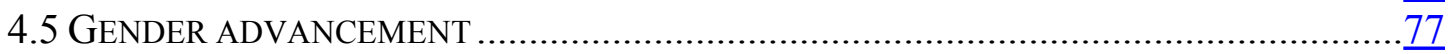

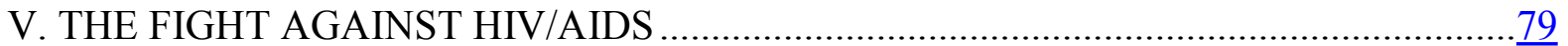

5.1 STATUS OF KNOWLEDGE OF THE VIRUS IN BURUNDI IN 2005 ............................... $\frac{79}{79}$

5.2 STATUS OF IMPLEMENTATION OF PRIORITY PROGRAMS ......................................

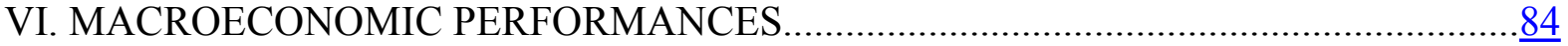

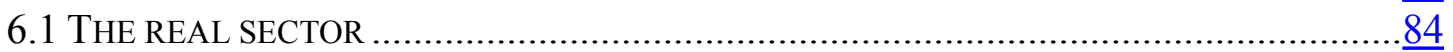

6.2 CHANGE IN INFLATION ........................................................................ $\frac{84}{85}$

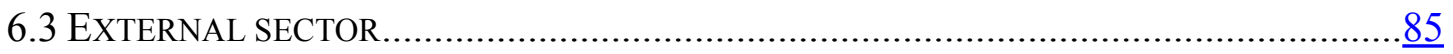

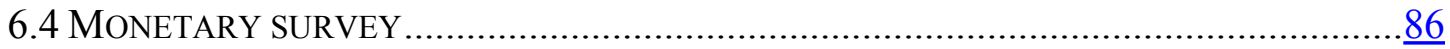

6.5 IMPLEMENTATION OF THE MONETARY AND FOREIGN EXCHANGE POLICY

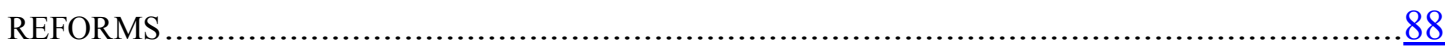

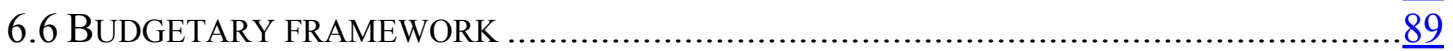

6.7 MACROECONOMIC PROJECTIONS ......................................................................

VII. PRSP MONITORING-EVALUATION SYSTEMS ….......................................

7.1 The InSTITUTIONAL Monitoring AND EVALUATION SYSTEM.............................101

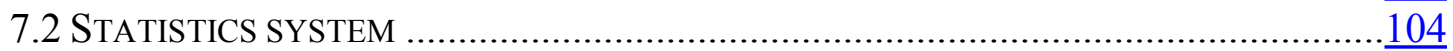

7.3 PERFORMANCE INDICATORS .....................................................................

Tables

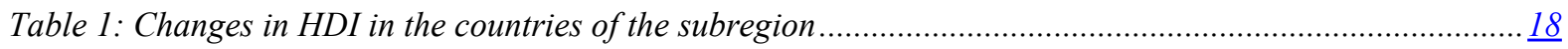

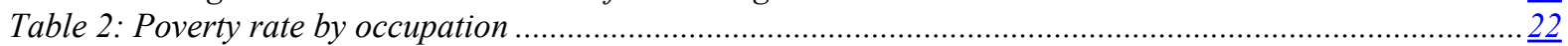

Table 3: Poverty and inequality by geographic or administrative location ………......................................... $\underline{23}$

Table 4: Status of demobilization program execution ............................................................................... 26

Table 5: Land tenure problems recorded in matters before the courts ......................................................... $\frac{31}{30}$

Table 6: Trend of food crop production in Burundi (in thousands of metric tons)........................................... $\frac{39}{42}$

Table 7: Export structure (in millions of Burundi francs)....................................................................... 42

Table 8: Changes in fish production, 1998-2007 (in kilograms).................................................................... 44

Table 9: Principal characteristics of microfinance in Burundi, 2007........................................................ 49

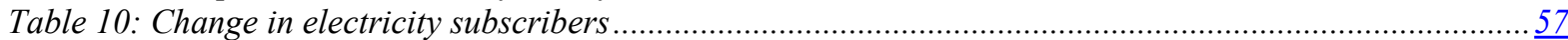

Table 11: External financing for the education sector in 2007 (millions of FBu) .......................................... 61

Table 12: Breakdown of school registrations in 2006.....................................................................

Table 13: Education performance indicators in 2006...............................................................................63

Table 14: Change in gross primary school enrollment rates by province ...................................................... $\frac{65}{65}$

Table 15: Nutritional status of children under five by province $(\%)$............................................................. $\frac{68}{\not 2}$

Table 16: Domestic financing through the government budget ……......................................................... $\frac{70}{73}$

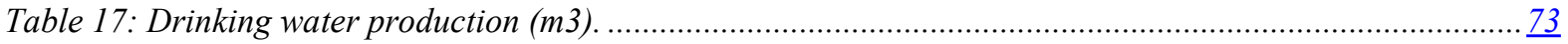

Table 18: Change in drinking water subscribers ………....................................................................

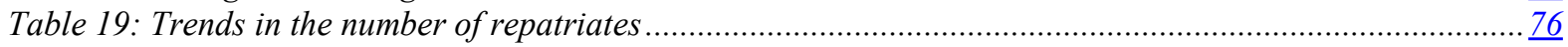

Table 20: Change in the real GDP growth rate (in 1996 prices)............................................................. $\frac{84}{85}$

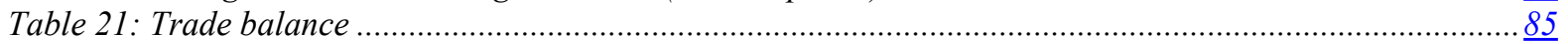

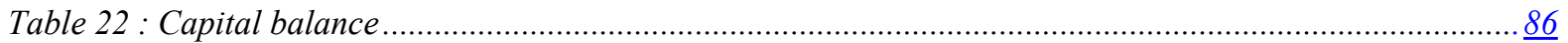

Table 23: Change in the principal monetary aggregates ........................................................................ $\frac{87}{90}$

Table 24: Breakdown of poverty-reducing and non-poverty reducing government expenditures....................... $\underline{90}$

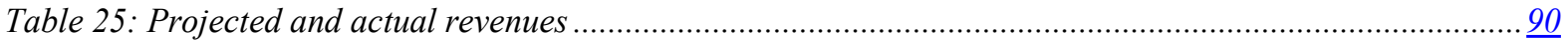

Table 26: Change in government expenditures (billions of $\mathrm{FBu}$ )...................................................................... 
Table 27: Financing of the budget deficits (billions of FBu).....

Table 28: 2006 revised budgetary expenditures (millions of FBu). .............................................................. 92

Table 29: 2007 enacted budgetary expenditures .....................................................................................

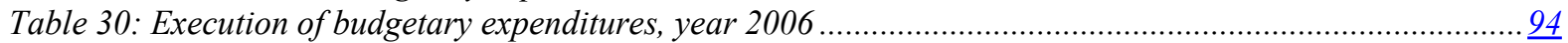

Table 31: Execution of budget expenditures in 2007 ..................................................................... 95

Table 32: Breakdown of poverty-reducing expenditures in the health sector (billions of FBu) ........................ 95

Table 33: Poverty-reducing expenditures in the education sector (billions of FBu)...................................... 96

Table 34: Execution of HIPC expenditures ................................................................................................. 97

Table 35: 2008-2011 economic projections. ........................................................................................... 99

Table 36: Donor promises during the roundtable, 2007..................................................................... 103

Table 37: Determinants of poverty in Burundi.................................................................................... 107

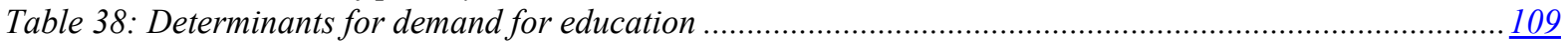

Table 39: Performance indicators matrix ........................................................................................... 111

\section{Charts}

Chart 1: Trends for inflation and the GDP.....

Chart 2: Per capita GDP growth (1 percent, 2 percent, 5 percent) and poverty projection.............................24

Chart 3: Herd size trend ....................................................................................................................... 43

Chart 4: Distribution of aid between donors and NGOs......................................................................

Chart 5: Urbanization trends in Burundi ................................................................................................

Chart 6: Several results indicators for AIDS (women from 15 to 49 years old) ..........................................79

Chart 7: Trend in condom distribution ................................................................................................... $\frac{81}{85}$

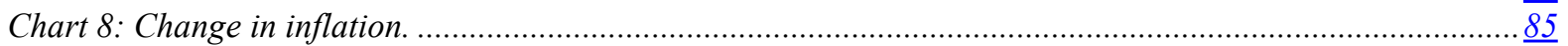

Chart 9: Change in the real effective exchange rate for the FBu (base $=2000)$........................................ 88 


\section{ACRONYMS AND ABBREVIATIONS}

\begin{tabular}{|c|c|}
\hline ADEN & : Digital Development Support Center \\
\hline $\mathrm{ADF}$ & : African Development Fund \\
\hline AfDB & : African Development Bank \\
\hline AIDS & : Acquired Immunodeficiency Syndrome \\
\hline BINUB & : United Nations Integrated Office in Burundi \\
\hline $\mathrm{BOB}$ & : Official Gazette of Burundi [Bulletin Officiel du Burundi] \\
\hline CCDLP & : Commune-level Development and Poverty Reduction Committee \\
\hline $\mathrm{CDF}$ & : Family development center \\
\hline CDS & : Health center \\
\hline CEPGL & : Economic Community of the Great Lakes Countries \\
\hline CERDA & : Center for Research and Development in Agro-Economy \\
\hline CFPP & : Vocational Training and Retraining Center \\
\hline CNDRR & : National Demobilization, Reinsertion, and Reintegration Commission \\
\hline CNIDH & : National Independent Human Rights Commission \\
\hline CNLS & : National Council to Combat AIDS \\
\hline CNTB & : National Commission on Land and other Assets \\
\hline COMESA & : Common Market for Eastern and Southern Africa \\
\hline CPI & : Consumer price index \\
\hline DAI & : Development Alternative Initiatives \\
\hline DAP & : Di Ammonium Phosphate \\
\hline DCPND & : National Decentralization Policy Strategy \\
\hline DGHER & : Directorate-General of Water Supply and Rural Energy \\
\hline DPAE & : Provincial Directorate of Agriculture and Livestock \\
\hline DPE & : Provincial Directorate of Education \\
\hline EAC & : East African Community \\
\hline ECCAS & : Economic Community of Central African States \\
\hline ENA & : National School of Administration \\
\hline EPI & : Expanded Program on Immunization \\
\hline FAB & : Burundi Armed Forces \\
\hline FAO & : Food and Agriculture Organization \\
\hline FBU & : Burundi franc \\
\hline FCE & : Common Education Fund \\
\hline FDN & : National Defense Force \\
\hline FHI & : Food for Hungry International \\
\hline FNL & : National Liberation Forces \\
\hline GDP & : Gross domestic product \\
\hline GTZ & : Gesselschaft für Technische Zusammenarbeit \\
\hline HCR & : High Commissioner for Refugees \\
\hline HDI & : Human Development Index \\
\hline
\end{tabular}




\begin{tabular}{|c|c|}
\hline HIPC & : Heavily Indebted Poor Countries Initiative \\
\hline HIPC & : Heavily Indebted Poor Country \\
\hline HIV/AIDS & $\begin{array}{l}\text { : Human Immunodeficiency Virus/Acquired Immunodeficiency } \\
\text { Syndrome }\end{array}$ \\
\hline HPRC & : Prince Régent Charles Hospital \\
\hline IDA & : International Development Association \\
\hline IDSR & : Integrated Disease Surveillance and Response \\
\hline IEC & : Information, Education, and Communications \\
\hline IFAD & : International Fund for Agricultural Development \\
\hline IMF & : International Monetary Fund \\
\hline INSS & : National Social Security Institute \\
\hline ISTEEBU & : Burundi Institute of Statistics and Economic Research \\
\hline JVMM & : Joint Verification and Monitoring Mechanisms \\
\hline MDG & : Millennium Development Goal \\
\hline MICS & : Multiple Indicators Cluster Survey \\
\hline MTEF & : Medium-Term Expenditure Framework \\
\hline NBI & : Nile Basin Initiative \\
\hline NEPAD & : New Partnership for Africa's Development \\
\hline NGO & : Nongovernmental organization \\
\hline NITC & : New Information and Communications Technologies \\
\hline ODA & : Official Development Assistance \\
\hline ONATEL & : National Telecommunications Office \\
\hline ONEF & : National Employment and Training Observatory \\
\hline OPEC & : Organization of Petroleum Exporting Countries \\
\hline OTRACO & : Mass Transit Office \\
\hline $\mathrm{OVC}$ & : Orphans and vulnerable children \\
\hline \multicolumn{2}{|c|}{ PALIPEHUTU: Party for the Liberation of the Hutu People } \\
\hline PLWHA & : People living with HIV/AIDS \\
\hline PMPA & : Political parties and armed political movements \\
\hline PMTCT & : Prevention of Mother-to-Child Transmission \\
\hline PNB & : National Police of Burundi \\
\hline PNLT & : National Program to Combat Leprosy and Tuberculosis \\
\hline PNSR & : National Reproductive Health Program \\
\hline PRSP & : Poverty Reduction Strategy Paper \\
\hline TA & : Preferential Trade Area \\
\hline REGIDESO & : Water and Electricity Production and Distribution Agency \\
\hline RESEN & : Status Report on the National Educational System \\
\hline RSA & : Republic of South Africa \\
\hline RTNB & : Burundi National Radio and Television \\
\hline SP/REFES & : Permanent Secretariat for Monitoring Economic and Social Reforms \\
\hline SSA & : Sub-Saharan Africa \\
\hline TMU & : Technical Memorandum of Understanding \\
\hline
\end{tabular}




$\begin{array}{ll}\text { UNDP } & \text { : United Nations Development Program } \\ \text { UNFPA } & : \text { United Nations Population Fund } \\ \text { UNICEF } & : \text { United Nations Children's Fund } \\ \text { USAID } & : \text { United States Agency for International Development: } \\ \text { WFP } & : \text { World Food Program } \\ \text { WHO } & : \text { World Health Organization }\end{array}$




\section{EXECUTIVE SUMMARY}

\section{BACKGROUND}

1. The first year of implementation under the PRSP framework took place in an environment characterized by the consolidation of security gains, political normalization thanks to the establishment of institutions following democratic elections, and the gradual resumption of partnerships with donors.

2. The approach taken to appraising the PRSP uses a participatory methodology, which was also used during preparation of the strategy paper. Consensus was thus reached during the three stages of the appraisal process, and consolidated in the course of the various feedback sessions.

3. First stage: Discussions with sectoral and topic-based groups entailed participation on the part of representatives of the administration, donors, and civil society. The work organized in this context highlighted the urgency of revitalizing the working parties and restoring the participatory approach.

4. Second stage: Participatory consultations were held in every commune and province of the country, affording the people the opportunity to express their views on performance on the ground, obstacles identified, and suggestions for improvements. This stage also made it possible to determine ways and means for strengthening the communelevel development and poverty reduction committees.

5. Third stage: Preparation of the matrix of indicators based on indicators selected in light of their availability, measurability, and reliability, constituted an important tool for assessing the progress made and any possible gaps to be bridged. Interpretation of the results obtained shows that notable progress has been made, although it is clear that improvements will be unavoidable in the years ahead.

6. In tandem with the above, and with World Bank Support, use of new data made available by the MICS-2005 and CWIQ-2006 surveys made it possible to update the poverty profile for Burundi. The new estimates indicate that the proportion of the population of Burundi living below the poverty line is on the order of 66.9 percent. 


\section{APPRAISAL FINDINGS}

\section{Axis 1: Improved governance and security}

7. For the government, the restoration of security and peace constitutes a prerequisite for economic recovery and poverty reduction. This being so, the highest priority was accorded to definitively bringing the conflict to end and with the resumption of work under the JVMM. The program for demobilizing former combatants was focused initially on the FABs, the PMPAs, police officers, and the militant combatants, and then on the soldiers from the FDN. As of end-December 2007 some 20,330 persons had been demobilized out of total manpower of 55,000. In contrast, the results of the programs for the reintegration and reinsertion of demobilized adults and children were below expectations. Similarly, the disarmament of the civilian population has yet to be carried out on a broad scale. However, the results with respect to mine clearing and education about the risk of mines are encouraging. Indeed, so far three provinces regarded as highrisk have been completely cleared of mines and the population of the at-risk provinces has been sensitized.

8. Consolidation of the rule of law is another of the primary concerns of the government. In order to improve access to justice, court construction, rehabilitation, and outfitting efforts have been initiated and surveys have been conducted about the perception of justice. The government also organized a campaign to heighten awareness about the ethics of judges. These judges also benefited from continuing training. Broad distribution of the legislative and regulatory texts, as well as additional codes and laws, has been facilitated by their translation into Kirundi.

9. The promotion and defense of human rights are the other priority areas for improving good governance and security. The efforts made have made it possible to produce the two preliminary draft laws on establishing the Independent Human Rights Commission and revising the criminal procedures code changing the age of criminal liability to 15 . Furthermore, a draft law revising the criminal code calls for abolition of the death penalty, a framework agreement has been signed for the establishment of transitional justice.

10. With regard to the land tenure issue, the government expects to address it in the context of social cohesion so as to impart sustainable solutions. To this end, the CNTB has been established to address land tenure disputes at the decentralized level. It currently has outreach units in every commune of the country. Second, the identification of available lands has been carried out in order to facilitate location of the landless. In conjunction with the above, the government is endeavoring to draw up a preliminary draft law on successions, matrimonial ownership arrangements, and gifts.

11. A number of decisive steps have been taken to promote political governance. First, training sessions organized for local elected officials and members of parliament have contributed to enhancing their management capacities. Second, in the legal area and looking forward to the next session of the States General on decentralization, a national decentralization and development policy letter has been adopted and the law organizing the Administration has been revised. Furthermore, the government created the ENA with 
a view to strengthening public administration and established the National Employment and Training Observatory. Third, the deconcentrated agencies have gradually been strengthened in terms of their human resources and equipment.

Axis 2: Promotion of sustainable and equitable growth

12. Livestock production did not significantly increase between 2006 and 2007, as a result of which the nutritional situation deteriorated. Indeed, the rate of growth of per capita food availability virtually stagnated, and remains well below the level of 19881993. Despite the lackluster short-term results, steps have been taken. These include in particular the redefinition of a development strategy for the agricultural sector, strengthening of the monitoring and evaluation system, making inputs available, strengthening extension services through the hiring of agronomists in every commune, the beginnings of an irrigation program, and continued marsh management.

13. Improving yields is unquestionably a major challenge to be met in order for there to be a significant increase in livestock production. In the short term, it will be important to adopt more effective measures for making quality inputs available on time and to initiate a program targeting more intensive water usage.

14. Regarding export crops, major reforms to deregulate the coffee, tea, and cotton subsectors have been initiated. These reforms should make it possible to rectify the current situation inasmuch as the production of these various crops, except in the case of tea, has been in overall decline. The reforms should also make it possible to improve the incomes of the farmers concerned. Small steps toward diversifying export products (sugar, rice, palm oil, flowering and fruit-bearing plants) have already begun.

15. The results of the program to develop animal production are broadly satisfactory. Rebuilding the herds destroyed during the crisis is well under way, as the growth rates for 2007 are high: 20 percent for cattle, 30 percent for goats, and 50 percent for pigs. The key actions behind these good results are probably the promotion of short-cycle stock rearing, artificial insemination, the increase in improved breeds, and support for livestock farmer groups. In order to increase food production and income possibilities, the extension of fish farming and fish processing should be encouraged.

16. Improvement of the environment is an important aspect of laying the groundwork for sustainable growth. Efforts along these lines are focused basically on the drafting and adoption of an environmental code and enhancing public awareness of environmental issues. Among the achievements made in 2007, 9,000 hectares of catchment basins and 2,500 hectares of marsh have been managed. Reforestation measures covered 3,400 hectares. The finalization of the implementing provisions of the environmental code and continued efforts in the aforementioned programs aimed at sustainable management of resources should be regarded as priorities.

17. The development of industrial, commercial, and artisanal units made progress in a number of respects. With support from development partners, a number of production units could be assisted. The regional project on coverage against political risks should have the effect of restoring investor confidence. A number of promoters have taken advantage of the benefits called for under the investment code. Activities relating to crafts and mining appear to have expanded moderately. Also noteworthy is the 
emergence of several microenterprises devoted to mining, the processing of agricultural products and hides, sewing, and finish carpentry. Progress has also been observed thanks to improved mechanisms for intervention in microfinance, the use of highly laborintensive techniques, and the initiatives carried out by the CDFs in favor of women.

18. The government has endeavored to ensure the full participation of youths in the process of consolidating social cohesion. The strengthening of the decentralized agencies in charge of youth, the development of new sporting infrastructures, and the organization of competitions at the national level, as well as the revitalization of cultural activities, have contributed to reaffirming the role and conduct of youths in society.

19. New programs for the construction of production-supporting infrastructure have been initiated. In the transport area, rehabilitation and modernization works have been launched for urban roads and inter-province connector roads. An initial series of feasibility studies has been conducted to assess the proposal for an intercity bus station in Bujumbura and the possibilities for linking Burundi to the Tanzanian railroad, modernization of transport on Lake Tanganyika, and paving of the Kirundo-Gesenyi section. Notable achievements in the telecommunications area include the establishment of a digital exchange in Gitega, the digitization of the RTNB studios, training sessions for journalists, and the extension of networks and broadened Internet access within the country. With respect to power production, the actions taken in 2007 were devoted to the rehabilitation of hydroelectric plants, extension of the distribution grid in peri-urban neighborhoods, and rural electrification (business centers, health centers, and communelevel secondary schools). Some progress was also made in respect of new and renewable energy sources, in particular as regards using solar power for health centers and the promotion of improved hearths.

20. Among the engines of growth, regional integration is regarded as a key factor, especially in connection with expanding market outlets and facilitating the supply of basic commodities. To this end, Burundi has joined the East African Community and is actively participating in the revitalization of CEPGL and the ECCAS.

\section{Axis 3: Promotion of human capital}

21. Making primary education free of charge has had highly positive effects on education. Accordingly, there has been an unprecedented rise in gross enrollment ratios as well as a decrease in gender inequality and inequalities between regions. The implementation of this measure benefited from a partnership framework involving the government, donors, development agencies, and the United Nations. This framework facilitated: (i) the preparation of a sectoral education and training plan and a corresponding action plan; (ii) preparation of a medium-term expenditure framework; and (iii) the creation of a common fund for education.

22. To address the surge in new pupils, the government, with the help of this partnership, undertook to increase capacities by building new schools or rehabilitating existing ones, and training and upgrading instructional staff. In addition, suitable instructional materials have been provided.

23. In the health field, spectacular progress was observed in 2007. Indeed, the decision to subsidize maternal care, the care of children under age 5, and the care of 
PLWHAs made it possible in particular to extend immunization coverage, which now exceeds 80 percent, and to increase the rate of childbirths in healthcare facilities from 22 percent in 2005 to 41.3 percent in 2007. Programs to combat malaria have been conducted and treated mosquito nets distributed. To address other diseases (malaria and diarrheic diseases), care facilities have been rehabilitated and equipped.

24. The efforts to improving living conditions are appreciable, although much remains to be done. Access to safe drinking water has been improved considerably, and is now greater than 88 percent. This development is largely attributable to the efforts made in developing or improving water supply systems and in increasing the number of water points. This said, in the housing area needs are still largely unmet, despite the volume of appropriations devoted to this sector (over FBu 13.5 billion in 2007) and the land parceling work performed to increase the supply of new lots.

25. The integration and reinsertion of war victims as well as the management of the flows of refugees returning from Tanzania have continued. The actions taken include the construction of shelters, assistance to the indigent and other vulnerable persons (orphans and children at risk), increase in the capacities of the basic social infrastructures (schools and health facilities), and an operation to identify new sites was initiated, indicating additional possibilities for locating the landless.

26. Enhancing the role of women in economic life and society continued, in particular through the training of paralegals in women's rights. It further involved improving access to credit, the intervention of the CDFs, and the broad dissemination of provisions on the protection of women. On a more global level, the Constitution of Burundi guarantees women's responsibilities in decision-making bodies, while the measures on free primary education and healthcare have had a highly significant impact on gender issues.

\section{Axis 4: Combating HIV/AIDS}

27. The CWIQ survey conducted in 2006 revealed that the challenges posed by HIV/AIDS were insufficiently understood by the public at large. In order to halt and gradually reduce the expansion of this pandemic, the government took actions based simultaneously on (i) the prevention of HIV/AIDS transmission; (ii) the provision of care to patients infected by HIV/AIDS; (iii) reduction of the impact on persons affected by HIV; and (iv) institutional capacity building.

28. The efforts made in the prevention area resulted in significant progress. Indeed, each census district now has two community-level animators, who total 6,550. Voluntary screenings have been provided to over 147,000 persons, the number of screening centers increased from 89 in 2002 to 151 in 2006, while the prevention of mother-to-child transmission of HIV/AIDS is now addressed in 84 sites as compared to 18 in 2005.

29. With respect to the provision of care to patients infected by HIV, training sessions for caregivers and for the providers of psychosocial care have been organized for doctors and nurses. The broader availability of antiretroviral treatments resulted in a sharp increase in the number of recipients, from 600 in 2002 to 10,800 in 2007. Reduction of the impact on persons affected by HIV has been initiated by conducting about 75 projects for PLWHAs, including support in the form of educational materials for OVCs and the 
distribution of agricultural inputs to host families. The desire to strengthen this provision of care was reflected by passage of the law on international solidarity on airplane tickets.

30. Finally, the institutional framework was also strengthened. The actions taken in this regard were focused on the preparation of a mapping of the various parties involved, the launch of a new national action plan in favor of OVCs for 2007-2011, and the development of databases at care sites.

\section{Macroeconomic performance}

31. Real GDP grew less rapidly than projected. Indeed, real GDP growth fell back from 5.1 percent in 2006 to 3.2 percent in 2007 . This poor performance, attributable to a drastic decline in the production of coffee and an increase in food crop production that was well below forecasts, was accompanied by a surge in prices that became even more pronounced beginning in June 2007. The price index increased by 14.4 percent from December 2006 to December 2007. This development, explained by the increase in the price of food products and fuels, further complicated the living conditions of the people, and in particular of the most vulnerable. This trend has continued, reaching 27 percent at end-April 2008.

32. The external sector was characterized by a relative improvement in the current balance, which amounted to -US\$117.5 million in 2007 as compared to -US\$133.5 million in 2006. International transfers, in particular of donor support, did make it possible to somewhat attenuate the scope of the current account deficit.

33. The monetary sector was characterized by a sharp increase in official reserves and a decrease in the use of advances to the state. At the same time, the volume of credit to the economy grew by 10.4 percent between 2006 and 2007. Generally, the national currency depreciated, a trend which contributed to higher inflation.

34. On the fiscal front, revenue improved thanks to the increases in some fees and in the income tax. Unquestionably, the implementation of new reforms targeting the streamlining of collection had a very positive impact on the performance of taxes and customs. Overall, revenue overshot the amount initially projected by $\mathrm{FBu} 5$ billion. On the expenditure side, because of the social measures adopted by the government in the fields of education and health, expenditure rose by about 13 percent between 2006 and 2007. The adoption of new policies will make it possible ultimately to have greater control over the level of public expenditure, particularly on the wage bill. With a change of 15.4 percent between 2006 and 2007, public investment outlays expanded quite significantly, in particular thanks to external resources.

35. The government has undertaken to allocate more resources in favor of the poor. The PRSP had called for a budget share on the order of 65 percent to be allocated to propoor spending. The budget laws for 2006 and 2007 called for proportions of 52.2 percent and 57.0 percent, respectively. In the event, the execution rate of pro-poor expenditure amounted to only 47.1 percent and 52.5 percent, respectively. Because not all fiscal revenues could be mobilized, and because the government had to address some expenditures that could not be compressed (remunerations and obligations associated with maintaining security), pro-poor spending could not be financed to the levels called for in the budget forecasts. 
36. The resources obtained in the form of debt relief from development partners contributed significantly to the financing of pro-poor expenditure. They amounted to FBu 14.4 billion in 2006 and rose to FBu 25.5 billion in 2007. These resources were used basically for the financing of activities in the health, education, agriculture, and water sectors.

\section{Monitoring and evaluation mechanisms}

37. Donor support is essential to the implementation and monitoring of the PRSP. The roundtable held in May 2007 constituted an excellent opportunity for establishing a permanent consultation framework. It also enabled donors to reaffirm their willingness to support this implementation by the mobilization of new resources estimated at US\$680 million over a three-year period.

38. The strengthening of the statistical apparatus is necessary for gathering and disseminating reliable data for measuring the progress made and gaps to be overcome. To this end, Burundi has already joined AFRISTAT. The impact of this move was already felt in 2007 in terms of the regular publication of the usual statistics (consumer price index for Bujumbura, the monthly price bulletin, the statistical yearbook, and the monthly bulletin on economic developments). Other targeted publications were also recorded, including in particular the national accounts, the 1-2-3 survey, and the MICS-2005 survey, with UNICEF support. By facilitating the institutional and technical coordination of the statistical system as a whole, the new statistics law should impart new dynamism to the production of statistics in Burundi.

39. Performance indicator data were gathered from the priority sectors identified by the PRSP. The data, which were collected in a participatory manner, made it possible to assess the general trends observed after one year of PRSP implementation. However, the structures that participated in the PRSP assessment process should be revitalized and strengthened so that they can assume genuine ownership. 


\section{INTRODUCTION}

40. By adopting the Poverty Reduction and Growth Strategy as a framework for government intervention in the economic, financial, and social areas, the government simultaneously undertook to conduct annual reviews in order to measure the progress made at regular intervals and to draw the lessons necessary for taking corrective measures.

41. The development partners as a whole have been supportive of the PRSP process and have already granted debt relief. Thus, upon adoption of the Interim PRSP in 2003, the member countries of the Paris Club granted forgiveness of their claims on Burundi until 2005, while multilateral creditors granted annual debt relief equivalent to about US\$36 million. With the publication of the first review of the PRSP, Burundi will have fulfilled one of the conditionalities agreed for reaching the completion point, the immediate effect of which will be forgiveness of about 92 percent of its external public debt.

42. The purpose of this report is thus to comply with the government's undertaking to report to the people on the results of its poverty reduction policy. Accordingly, the progress report on the actions taken and reforms implemented one year after PRSP adoption has been the subject of feedback sessions with all stakeholders.

43. This report indicates, in respect of each of the four PRSP axes, the status as regards the manner in which objectives have been achieved, the actions taken, possible constraints, and programs to be implemented in the short term. The preparation of this first review adheres to the same participatory dynamic that is always preferred for the PRSP process, thereby bearing witness to the effort to ensure sustained involvement on the part of the various stakeholders.

\section{The report is structured as follows:}

Chapter 1: Recent sociopolitical and economic developments

Chapter 2: Improved governance and security

Chapter 3: $\quad$ Promotion of sustainable and equitable growth

Chapter 4: Development of human capital

Chapter 5: Combating HIV/AIDS

Chapter 6: Macroeconomic performance

Chapter 7: Monitoring and evaluation mechanisms 


\section{RECENT SOCIOPOLITICAL AND ECONOMIC DEVELOPMENTS}

44. The preparation of the first report on PRSP implementation, the contents of which were adopted by the government in September 2006, took place in a general environment marked by the stabilization of security, political normalization, and multifaceted efforts aimed at economic recovery and improving the living conditions of the people.

45. Although cyclical economic developments may have had an impact on anticipated performance in terms of meeting the objectives set, the government's objective to move forward toward the consolidation of peace, improving access to basic social services, and strengthening the partnership with its partners, made it possible to lay groundwork favorable to execution of the priority actions of the PRSP.

\subsection{Political and security developments}

\section{Political situation}

46. An historical threshold was crossed with the free and transparent electrics that allowed for the establishment of democratic institutions not only at the central level but at the various decentralized levels. Subsequently, the government has gradually improved the framework for dialogue and consultation among all stakeholders in the political sphere of Burundi. A serene environment conducive to the restoration of confidence among all population groups was thus restored. The resumption of discussions with the FNL/PALIPEHUTU and the establishment of a National Unity Government in November 2007 are further signs of this approach. They also reflect the political will to overcome the spillover effects of the armed conflict and to strengthen the dynamic of renewed peace.

47. Difficulties did arise, however, in the work of the parliament, which could not be organized on a regular basis. This problem, which persisted throughout 2007 , delayed the passage of draft laws which are nonetheless essential for the harmonious execution of essential reforms.

\section{Security conditions}

48. The situation is calm throughout almost the entire national territory. All provinces are now accessible. Consequently, economic activity could be resumed all over the country. The concerted efforts made by the government and its partners have opened new horizons for the consolidation of peace. Noteworthy developments include the establishment of a political directorate responsible for strengthening mediation in the negotiation process with the FNL with a view to definitively ceasing hostilities. As a 
consequence, last-minute foot-dragging on the part of the last political movement still under arms have just given way to greater hope, in that its delegates have resumed work within the JVMM, thereby revitalizing a climate of confidence among the parties.

\section{Social and economic developments}

49. GDP growth was irregular, rising from 0.9 percent in 2005 to 5.1 percent in 2006. It slipped the following year, owing in particular to a sharp decline in coffee production, which dropped from 30,000 metric tons in 2006 to 8,000 metric tons in 2007. The economy remains extremely sensitive to climatic risks and the performance of the coffee sector. In consequence, GDP growth was only 3.2 percent at end-2007.

50. The consumer price index rose considerably from 9.6 percent for 2006 to 14.4 percent in 2007 , mainly owing to the upward revision of certain fees and to higher costs for food products.

Chart 1: Trends for inflation and the GDP

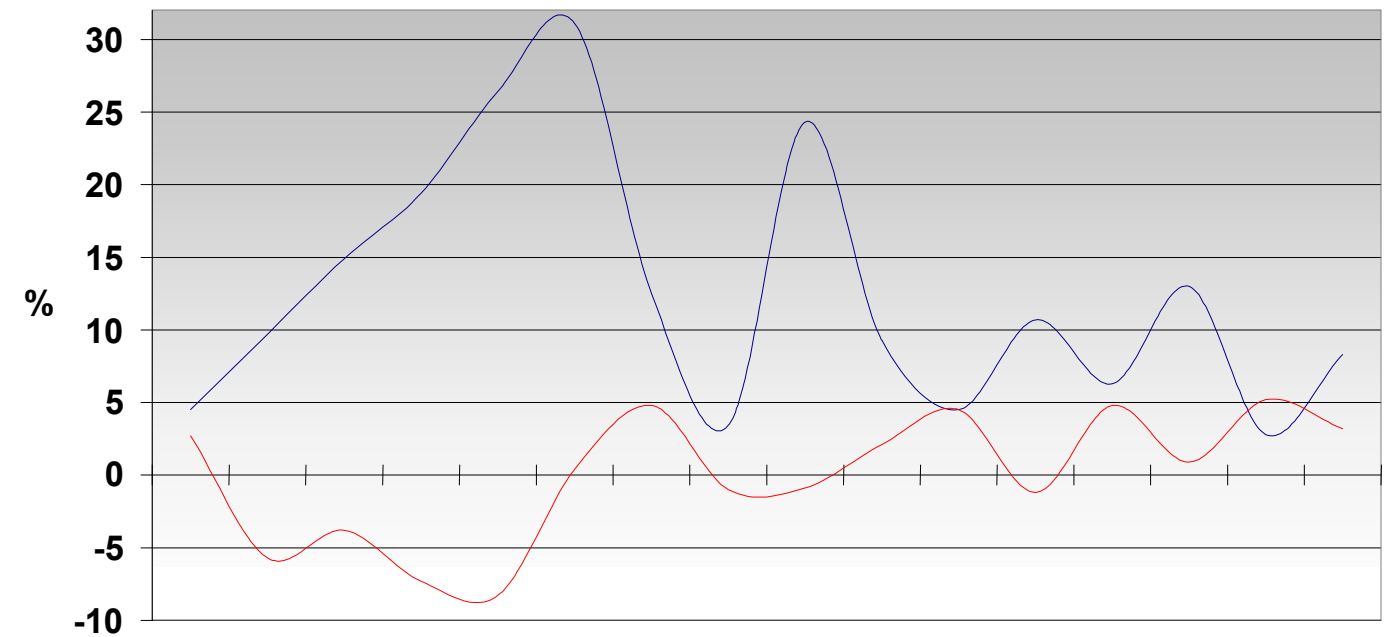

1992199319941995199619971998199920002001200220032004200520062007

Year

Source: ISTEEBU.

51. Public finances were characterized primarily by the growth in public revenue, which increased from FBu 178.8 billion in 2006 to $\mathrm{FBu} 197.8$ billion in 2007. This change is largely attributable to improved collection rates, which made it possible to boost the revenue level to approximately 18.7 percent of average annual GDP for the past two years. However, the substantial increase in the wage bill strongly weighed on the budget, maintaining expenditure at a very high level (24.7 percent of GDP in 2007). At end-2006, outstanding external debt was equivalent to US\$1,516.1 million, or 165 percent of GDP. With the support of the international community, Burundi was able 
to benefit from external debt relief vis-à-vis Paris Club member countries. The second stage was reached in 2005 when Burundi reached the decision point.

52. The state's cash flow difficulties also resulted in sizable domestic arrears to the private sector. With the support of the World Bank, an exhaustive inventory of creditors was drawn up and a plan for clearing arrears was adopted starting in fiscal 2006. The strategy adopted in this regard consisted in cash payment of a portion of the arrears and in the issuance, with the assistance of the BRB, of Treasury bonds for the remainder.

53. Monetary policy has remained prudent overall. Indeed, despite the persistence of the fiscal deficit, the recourse to bank financing was contained and money supply growth limited to 10.1 percent for M2 and 15.8 percent for M3 in 2007, as compared to nominal GDP growth of about 10 percent. Concerning exchange policy, the strengthening of the auction system was accompanied by substantial exchange rate liberalization of the foreign exchange rate and a significant reduction in the gap between the official and parallel market rates.

54. As in the past, foreign trade is characterized by a persistent trade deficit. The predominant share of coffee in the export structure continued, as the product accounted for over 60 percent of receipts. On the import side, petroleum products are still the key component, accounting for 22.7 percent of the total c.i.f. value of imports. The surge in petroleum product prices led to a more rapid rise in the value of imports than of exports. The trade deficit expanded from 16.6 percent of GDP in 2005 to 21.2 percent of GDP in 2007.

55. The current official transfers generated by external assistance failed to have the anticipated impact on the external current account because of (i) the low level of such transfers and (ii) the high cost of commercial transactions resulting from the fact that Burundi is landlocked. The current account thus posted a negative balance of -US $\$ 133.5$ million in 2006, that is, -14.5 percent of GDP.

\section{Human development}

56. Burundi has made notable efforts aimed at improving the living conditions of the people. The progress made in this area is reflected in Table 1, which shows HDI changes. Between 2000 and 2005, this indicator improved in relative terms from 0.368 to 0.413 . However, Burundi is still 167th out of the 177 countries ranked. Burundi also lags considerably behind the progress made by neighboring countries with comparable economic structures. This suggests that even greater efforts are necessary in order to increase human development.

Table 1: Changes in HDI in the countries of the subregion, 1975-2005

\begin{tabular}{|l|l|l|l|l|l|}
\hline Year & Kenya & Rwanda & Zambia & Burundi & DRC \\
\hline 1975 & 0.466 & 0.337 & 0.470 & 0.290 & 0.414 \\
\hline 1980 & 0,514 & 0,385 & 0,478 & 0,318 & 0,423 \\
\hline 1985 & 0,534 & 0,403 & 0,489 & 0,352 & 0,430 \\
\hline 1990 & 0,556 & 0,340 & 0,477 & 0,366 & 0,423 \\
\hline 1995 & 0.544 & 0.330 & 0.439 & 0.347 & 0,391 \\
\hline 2000 & 0,529 & 0,418 & 0,420 & 0,368 & 0,375 \\
\hline
\end{tabular}

Source: United Nations Annual Report on Sustainable Human Development (2007-2008). 


\subsection{PRSP monitoring and evaluation mechanisms}

\section{Monitoring and evaluation objectives}

57. The PRSP monitoring and evaluation system must make it possible to revisit strategies and to refocus the resources mobilized in order to impart greater effectiveness to the implementation of poverty reduction programs. Accordingly, the first PRSP review is aimed at achieving three goals, namely: (i) to verify the effectiveness of the actions taken within the framework of the poverty reduction effort and make any readjustments that may be deemed necessary; (ii) to measure the results attained; and (iii) to target appropriate measures for better addressing the obstacles to sectoral performance.

\section{Selection of monitoring indicators}

58. The proposal for indicators to monitor the results of Burundi's PRSP was broadly inspired by the Reference Framework and Common Minimum Methodological Guidelines for designing a PRSP and MDG information tracking system in the AFRISTAT Member States, known by its acronym CRESMIC. The simplified matrix for PRSP monitoring thus drawn up gathers together, by specific PRSP objective and strategic axis, the information gathered over the past two years, and wherever possible includes the target set for 2010. This approach led to some give-and-take and often focused on the indicator's capacity to directly measure the progress made in the short term and the capacity of the national statistical system to provide the information/data needed for the indicator (the capacity of the statistical system to assume ownership of the indicator).

59. An initial list of PRSP monitoring indicators that were sufficiently reliable, measurable, and available was thus drawn up in a participatory manner. It includes certain key PRSP monitoring indicators for which information is available as well as other supplementary indicators which must be the subject of in-depth research in the course of future reviews. Most of these supplementary indicators are related to the first axis relating to governance and security. To facilitate measurement of the progress made, realistic targets were set, with particular reference to the aims of the MDGs and special emphasis on those indicators likely to be well documented by the national statistical system. Finally, analysis of the gaps and performance shortfalls during participatory evaluation should make it possible to define new policies and identify urgent actions to be taken.

\section{Participatory process}

60. For annual evaluation purposes, priority was accorded to the revitalization of structures and institutions that took part in the initial preparation of the PRSP.

\section{Revitalization of the sectoral and topic-based committees}

61. Intensive consultations were held within each ministry to bring the list of members up to date. The composition of the list was validated at the level of each department. As when the PRSP was being formulated, each of the subcommittees 
updated in this manner includes representatives of (i) the central administration, (ii) donors, (iii) international NGOs, and (iv) civil society. Their respective contributions made it possible to draft a sectoral appraisal report on the PRSP, the contents of which were validated by the various parties concerned.

Revitalization of the provincial and commune-level development and poverty reduction committees

62. Community assessment of the PRSP was preceded by identification of the members of the commune-level development and poverty reduction committees who were to participate in the work, in collaboration with representatives of the communal councils. The choice of the delegates called upon to be part of the CCDLPs, whose composition was to be broadly representative, required close collaboration between the communal authorities and community representatives. The evaluation work organized within this framework made it possible to identify any omissions that may have somewhat undermined participatory dynamics at the community level and to identify new measures making it possible to revitalize dialogue.

63. The major dysfunctional aspects identified concern the following:

(i) Insufficient taking into account of civil society

(ii) Poor coordination of the contributions of NGOs

(iii) A lack of measures accommodating the decentralization policy

(iv) Inconsistency between the approaches taken by commune-level law and the modalities espoused for the establishment of the CCDLPs.

64. Upon conclusion of the discussions, the following results were achieved:

(i) Broad dissemination of the contents, stakes, and challenges of the PRSP

(ii) Enhanced media outreach through the production of a documentary film, reinvigoration of the PRSP Internet site, and the distribution of a national language pamphlet summarizing the key stages of the PRSP

(iii) Ownership of the PRSP process PRSP by all the active and concerned structures, and enhanced awareness of the need to conduct annual reviews.

$1.4 \quad$ Poverty profile

\section{Context}

65. The civil war that broke out in Burundi in 1993 plunged the country into armed combat, chronic poverty, social fracture, and food insecurity. The fifteen years of conflict just concluded have cost the lives of over 300,000 people and forced another 1.2 million (16 percent of the population) to flee their homes. Combined with the brutal recession triggered by the war, the political and economic embargo of 1996-1999 led to a decade of unprecedented national impoverishment. Per capita GDP fell by 33 percent, and poverty grew worse and worse.

66. The most recent estimate of the incidence of poverty in Burundi indicates that nearly 67 percent of the population lives below the level of consumption that ensures the minimum vital to the individual. Household purchasing power is inexorably exhausted and the coverage of basic needs is becoming increasingly problematical for those who are 
most vulnerable. The prices of basic foodstuffs are spiking in an unprecedented way. Noteworthy among the plausible explanatory factors behind this price inflation are:

(i) The drop (of 28 percent between 1993 and 2006) in annual per capita agricultural production, increasing the dependence of households on products traded on the markets for their food;

(i) The price increases for fuels (gasoline and gas-oil), which drove up transport costs, with the latter ultimately reflected in wholesale and retail prices; and

(ii) Depreciation of the Burundi franc $(\mathrm{FBu})$ vis-à-vis the U.S. dollar, which increased the price of imports.

67. The poverty estimates most known in Burundi are based on the results of the Priority Survey of 1998-99 (ISTEEBU). These estimates were made using a poverty line broken down into a food threshold and nonfood threshold. In this study, the food poverty line is defined as the monetary equivalent of the minimum number of calories required by an adult individual to guarantee daily subsistence. Determining the food poverty line includes three stages:

(i) Identification of the essential goods consumed by households;

(ii) Calculation of the caloric value of the goods basket $(2,400$ kilocalories constitute the daily intake necessary for an adult according to international standards);

(iii)Estimation of the price of the goods in the basket.

68. The nonfood poverty line was estimated by using the average nonfood expenditure of households for which the standard of living is close to the food poverty line. Finally, the total poverty line is the sum of the food and nonfood poverty lines. Given the considerable differences in living conditions in urban and rural areas, it was necessary to prepare separate estimates so as to have a specific poverty line for each environment. Accordingly, the poverty lines used for estimating the number of poor in 1998-99 were $\mathrm{FBu} 103,730$ a year in rural areas and FBu 182,725 a year in urban areas.

\section{Updating measurement of the scope of income poverty in Burundi}

69. With the recent completion of the MICS 2005 and CWIQ 2006 surveys, the country has solid data that make it possible to update the statistics on poverty. The poverty estimate from the CWIQ 2006 survey tends in general to confirm the considerable scope of the problem in Burundi, in particular in rural areas. Using a methodology similar to that of the 1998-99 survey, estimating the number of poor in 2006 was carried out on the basis of a food and nonfood poverty line of approximately $\mathrm{FBu} 627$ per day and per adult equivalent for urban areas, and approximately $\mathrm{FBu} 525$ per day and per adult equivalent for rural areas. It thus appears that the share of the poor population is about 69 percent in rural areas, 34 percent in urban areas, and 66.9 percent nationally. The estimates for 1998-99 yielded the not readily comparable figures of about 83.7 percent outside the capital ("rural" areas), 41.4 percent in Bujumbura Mairie, and 81.1 percent nationally.

70. It is nevertheless advisable not to conclude that there has been a reduction in poverty between 1998-99 and 2006. Indeed, given that per capita GDP remained stable at best between the two periods, it is likely that the incidence of poverty changed only very 
little in the interval, and that level of poverty is closer to the 67 percent of CWIQ 2006 than to the 81 percent announced following the priority survey. Simulations with the latter figure also suggest that the poverty changed very little 1998-99 and 2006. This prudent assessment is further corroborated by the results of the survey on the perceptions of poverty conducted in 2004. These results indicated that over 70 percent of the persons questioned think that poverty had instead increased a great deal (50 percent) or somewhat (20 percent) between 1999 and 2004. Moreover, there really are problems of comparability between the results of the two surveys, which were conducted in different periods, with different consumption/GDP ratios, and different urban and rural food baskets.

\section{Characteristics of the poor}

71. The estimates of income poverty leave little doubt about the persistent and widespread nature of poverty in Burundi. While sizable differences do exist, poverty affects households from almost every sector of activity.

Table 2: Poverty rate by occupation

\begin{tabular}{|l|c|c|c|}
\hline \multirow{2}{*}{\multicolumn{1}{|c|}{ Occupation }} & \multicolumn{2}{c|}{ Population } & \multirow{2}{*}{$\begin{array}{c}\text { Poverty } \\
\text { (percent) }\end{array}$} \\
\cline { 2 - 4 } Food crops & Number & Percent & 72.50 \\
\hline Export crops & $3,166,170$ & 39.58 & 68.18 \\
\hline Livestock and other agriculture & 638,826 & 7.86 & 68.37 \\
\hline Informal private sector wage earners & $1,686,876$ & 20.53 & 22.66 \\
\hline Unskilled informal private sector wage earners & 139,935 & 1.47 & 57.06 \\
\hline Informal sector-services & 650,352 & 7.62 & 56.88 \\
\hline Other informal sector & 251,839 & 2.94 & 64.43 \\
\hline Skilled public sector wage earners & 264,634 & 3.03 & 11.34 \\
\hline Unskilled public sector wage earners & 149,349 & 1.52 & 52.33 \\
\hline Not actively employed & 116,010 & 1.25 & 71.54 \\
\hline Total & 946,440 & 14.19 & $\mathbf{6 6 . 8 6}$ \\
\hline
\end{tabular}

Source: CWIQ-2006.

72. Except in the case of the households of skilled wage earners in the informal private sector or public sector (registering 23 percent and 11 percent, respectively), it is important to note that there are many sectors of activity in which over half the population can be regarded as poor. For example, 73 percent of the households working in the food crop sector live below the poverty line.

73. Apart from the sector of activity of the head of household, poverty has also been correlated with a number of other characteristics (Table 37). For example, the higher the level of education of the head of household, the greater the per capita consumption of that household. Conversely, household size, disabilities, unemployment, and the status of having been a refugee, have a negative correlation with household consumption and are consequently factors that aggravate poverty. There is no question but that a rapid and sustainable emergence from poverty in Burundi calls for precise targeting of the 
population groups that are hard hit by destitution and precarious living conditions. The factors in income poverty thus identified can indeed support effective targeting.

Table 3: Poverty and inequality by geographic or administrative location

\begin{tabular}{|c|c|c|c|c|c|}
\hline Location & $\begin{array}{l}\text { Incidence of } \\
\text { poverty }\end{array}$ & $\begin{array}{l}\text { Poverty gap } \\
\text { (PG) }\end{array}$ & $\begin{array}{c}\text { Square of poverty } \\
\text { gap (SPG) }\end{array}$ & $\begin{array}{c}\text { Gini } \\
\text { Coefficient }\end{array}$ & $\begin{array}{c}\text { Ratio of } \\
\text { consumption of } \\
\text { the most well-off } \\
\text { to that of the } \\
\text { poorest }\end{array}$ \\
\hline Urban & 34.0 & 0.103 & 0.042 & 0.485 & 6.6 \\
\hline Rural & 68.9 & 0.242 & 0.105 & 0.365 & 4.3 \\
\hline Bubanza & 57.0 & 0.167 & 0.066 & 0.429 & 4.2 \\
\hline Bujumbura Mairie & 28.7 & 0.084 & 0.034 & 0.471 & 6.7 \\
\hline Bujumbura Rural & 64.3 & 0.187 & 0.073 & 0.320 & 4.3 \\
\hline Bururi & 56.7 & 0.174 & 0.067 & 0.388 & 4.8 \\
\hline Cankuzo & 67.7 & 0.238 & 0.105 & 0.352 & 4 \\
\hline Cibitoke & 59.5 & 0.184 & 0.072 & 0.395 & 4.2 \\
\hline Gitega & 68.2 & 0.226 & 0.093 & 0.366 & 4.7 \\
\hline Karuzi & 68.9 & 0.244 & 0.106 & 0.333 & 4.8 \\
\hline Kayanza & 75.5 & 0.289 & 0.128 & 0.327 & 3.6 \\
\hline Kirundo & 82.3 & 0.322 & 0.148 & 0.257 & 3.8 \\
\hline Makamba & 57.3 & 0.180 & 0.074 & 0.414 & 4.7 \\
\hline Muramvya & 70.0 & 0.237 & 0.101 & 0.270 & 3.9 \\
\hline Muyinga & 70.5 & 0.268 & 0.122 & 0.381 & 4.3 \\
\hline Mwaro & 61.5 & 0.209 & 0.087 & 0.289 & 4.1 \\
\hline Ngozi & 75.4 & 0.302 & 0.143 & 0.339 & 4.0 \\
\hline Rutana & 72.9 & 0.260 & 0.111 & 0.318 & 4.0 \\
\hline Ruyigi & 76.0 & 0.282 & 0.126 & 0.292 & 3.7 \\
\hline National & 66.9 & 0.234 & 0.101 & 0.385 & 4.8 \\
\hline
\end{tabular}

Source: CWIQ 2006.

74. As regards the depth of poverty, Table 3 shows a poverty gap of 23.4 percent, which clearly highlights a situation worthy of concern, for rural areas in particular. As for the inequalities which negatively impact the distribution of consumption by the people, the Gini coefficient (0.385) is indicative of the scope of the problem in Burundi.

75. Increasing agricultural production is unquestionably one path for rapidly emerging from the poverty that afflicts the vast majority of the population. Chart 2 below depicts scenarios indicating the plausible trajectory of the poverty level in the years ahead for growth rates of 1 percent, 2 percent, and 5 percent, respectively, when maintained and sustained throughout the entire simulation period. 
Chart 2: Per capita GDP growth (1 percent, 2 percent, 5 percent) and poverty projection

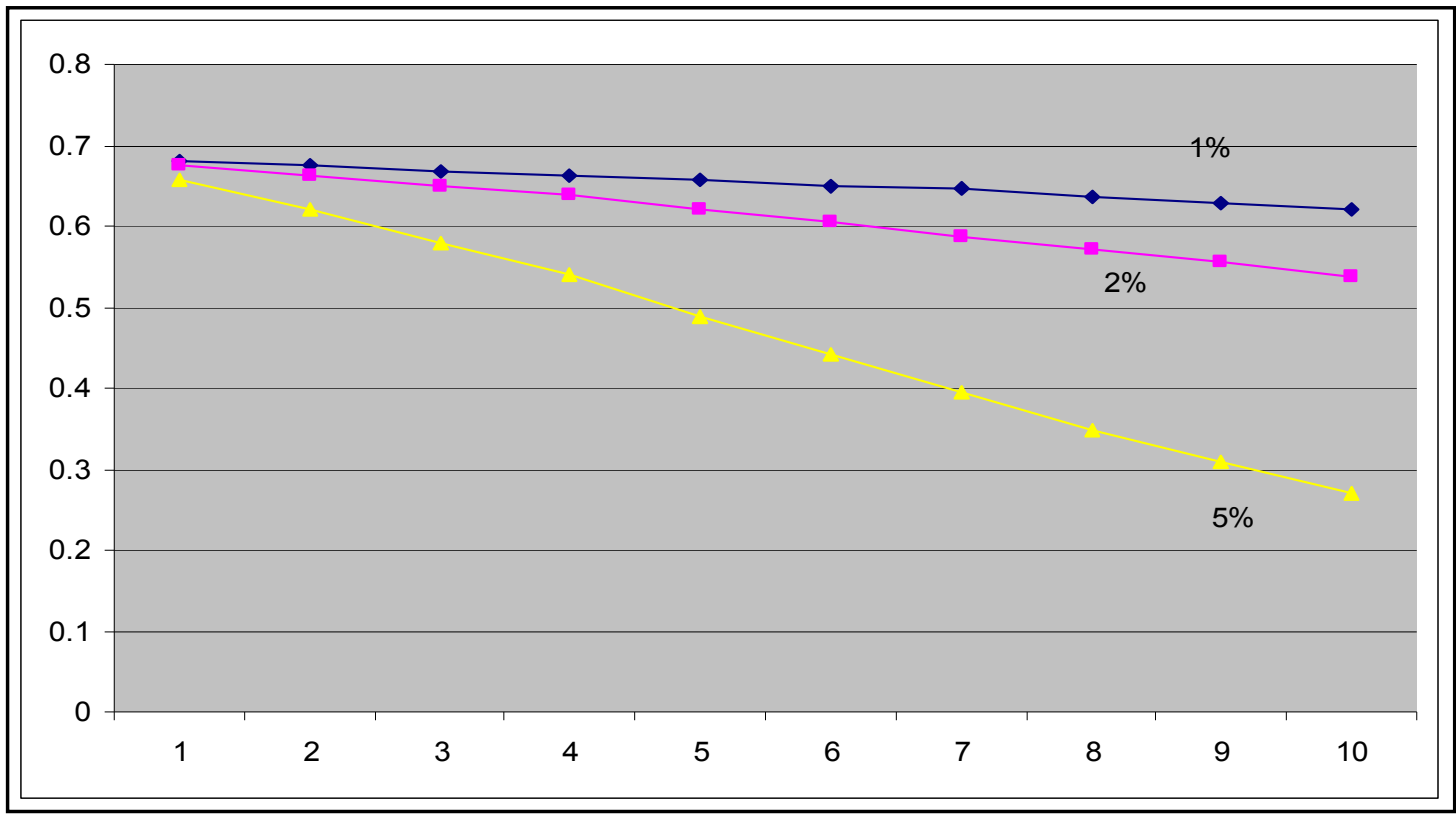

Source: World Bank estimates.

76. Starting from the current poverty level of roughly 67 percent, this chart shows that it will take about 8 years at least to be able to reduce poverty in Burundi by half by 2016 . This goal would be achieved only by maintaining a GDP growth rate of 5 percent a year. At lower rates of economic growth (1 percent or 2 percent), this goal will probably never be met. Moreover, the efforts of economic growth needed for sustainable poverty reduction will be in vain without any real policy to control population growth. An analysis of the determinants of poverty in 2006 highlights the existence of a negative correlation between the size and composition of the household, on the one hand, and its per capita consumption, the other (see Table 37 ).

\subsection{Sectoral performance}

77. Burundi's PRSP identified four axes that are part of a comprehensive vision for sustainable economic growth and poverty reduction. For each axis, the Poverty Reduction Strategy Paper (PRSP) indicates the priority policies and actions. Since the adoption of the PRSP in September 2006, a number of programmed activities have begun to be implemented within the sectoral ministries and institutions concerned.

78. It is thus important to take stock of the degree of completion of the priority actions and of the constraints that have impeded or slowed their implementation. This first review of the PRSP also provides an opportunity to refocus the outcomes matrix and to fine-tune the new policies and reforms to be initiated to correct the errors identified. The approach adopted for this purpose consists in reviewing the execution status of the priority programs in each of the four axes, focused on: (i) improving governance and security; (ii) promoting sustainable and equitable growth; (iii) promoting basic social services; and (iv) combating HIV/AIDS. 


\section{IMPROVING GOVERNANCE AND SECURITY}

2.1 Strengthening peace, national reconciliation, and security

79. The necessary interaction between peace and development is at the very foundation of the PRSP. In this regard, four programs focused on strengthening security were envisaged, namely: (i) negotiation of the ceasefire; (ii) demobilization, disarmament, and reintegration; (iii) professionalization of the defense and security forces; and (iv) disarmament of the civilian population.

Negotiation of the ceasefire

80. On September 6, 2007, the government of Burundi concluded a total ceasefire agreement with PALIPEHUTU/FNL, the only armed movement still active. Implementation of the agreements concluded was considerably delayed. Much banditry, many murders, and a resurgence of road ambushes were observed as well. At end-2007, the Regional Initiative granted an additional 12 months' time to the Mediator in the Burundian conflict to enable it to relaunch and complete the inter-Burundian negotiations. A political directorate made up of the United Nations, the African Union, and the government of Burundi was to assist the mediation team in establishing a work methodology to speed up the negotiation process. The United Nations Security Council renewed the mandate of the United Nations Integrated Office in Burundi (BINUB) for one year. Finally, a special force from the African Union has been tasked with ensuring the application of the ceasefire agreement.

\section{Demobilization, disarmament, and reintegration}

81. The policy on the demobilization and reinsertion of former soldiers and excombatants initiated in 2003 is continuing through the activities of the National Demobilization, Reinsertion, and Rehabilitation Program (PNDRR) with the support of the MDRP/World Bank program. Its objective is to take part in the return to peace and its consolidation in Burundi and the subregion, and to facilitate application of the contents of the Arusha Accord and of the various other ceasefire agreements signed since. In practical terms, the objectives to be reached are: (i) the demobilization, reinsertion, and reintegration of 55,.000 ex-combatants from the Burundi Armed Forces (FAB) and the Political Parties and Armed Political Movements (PMPAs), (ii) the reinsertion of some 20,000 members of the police forces and 10,000 militant combatants from the PMPAs, and (iii) the reallocation of military expenditure in favor of the economic and social sectors.

82. An overview of demobilization activities as at 12/31/2007 indicates a total result of 20,330 persons demobilized, including 506 women and 3,042 children. According to the results of a count conducted in December 2007, overall manpower was 27,570 in the FDN and 17,693 in the PNB, for a total of 45,263. It follows that 2,570 FDN personnel and 2,693 PNB personnel, or a total of 5,263, had still to be demobilized to reach the final manpower levels envisaged of 25,000 for the FDN and 15,000 for the PNB. 
83. The main activities carried out relate to the demobilization and socioeconomic reintegration of 3,041 children associated with the armed forces and armed movements, support for ex-combatants through 13 projects, support for income-generating activities by ex-combatants, and vocational training in entrepreneurship through small projects. The execution status of projects in the portfolio as of 12/31/2007 is summarized in Table 4 below.

Table 4: Status of demobilization program execution

\begin{tabular}{|c|c|c|c|c|c|c|c|}
\hline \multirow{2}{*}{ Stage } & \multirow{2}{*}{ Target group } & \multicolumn{2}{|c|}{ Demobilization } & \multicolumn{2}{|c|}{ Reinsertion } & \multicolumn{2}{|c|}{ Reintegration } \\
\hline & & Plan & Actual & Plan & Actual & Plan & Actual \\
\hline \multirow{6}{*}{ Phase I } & FAB \& PMPAs & 14,000 & 20,330 & 14,000 & 20,330 & 13,100 & 12,687 \\
\hline & \multirow{2}{*}{$\begin{array}{l}\text { Adults } \\
\text { Children }\end{array}$} & 9,000 & 17,283 & 9,000 & 17,283 & 8,100 & 12,687 \\
\hline & & 5,000 & 3,041 & 5,000 & 3,041 & 5,000 & \\
\hline & Police forces and militant combatants & 30,000 & 28,383 & 30,000 & 28,383 & 3,000 & - \\
\hline & \multirow{2}{*}{$\begin{array}{l}\text { Adults } \\
\text { Children }\end{array}$} & 27,000 & 28,383 & 27,000 & 28,383 & - & - \\
\hline & & 3,000 & - & 3,000 & - & 3,000 & - \\
\hline \multirow{3}{*}{ Phase II } & National Defense Force (FDN) & 41,000 & 4,174 & 41,000 & 4,174 & 36,900 & 363 \\
\hline & \multirow{2}{*}{$\begin{array}{l}\text { Adults } \\
\text { Children }\end{array}$} & 41,000 & 4,174 & 41,000 & 4,174 & 41,000 & 363 \\
\hline & & 0 & 0 & 0 & 0 & 0 & 0 \\
\hline \multicolumn{2}{|c|}{ Total Armed Forces } & 55.000 & 24.504 & 55.000 & 41.793 & 50.000 & 13.050 \\
\hline
\end{tabular}

Source: World Bank.

84. ILO and FAO support for the demobilization program will make it possible to increase direct assistance for ex-combatants and strengthen the partnership for program implementation. The ILO plans in particular to: (i) build the professional, entrepreneurial, and managerial capacities of 1,200 demobilized individuals and to help them initiate or recast micro- and small sole proprietorships or collective enterprises depending on the opportunities presented by the reintegration environment; and (ii) enhance the capacity of the SE/CNDRR to provide support and monitor NGOs in promoting nonagricultural AGRs. For its part, the FAO intends to: (i) provide ex-combatants with 25,000 agricultural kits adapted to the various agro-ecological conditions for starting up activities during the first crop season of 2008; and (ii) provide technical assistance to the Ministry of Agriculture and Livestock, to the SE/CNDRR, and to their partners, in respect of the reinsertion and reintegration of ex-combatants.

85. The Executive Secretariat of the PNDRR has also signed two cooperation agreements to assist handicapped former combatants with their physical and medical rehabilitation as well as to provide socioeconomic support. It has also financed the rehabilitation of 56 commune-level infrastructure projects based in the areas where excombatants are concentrated. Future efforts include the demobilization and reintegration of the children associated with the FNL, speeding up the economic reintegration of all demobilized former combatants, and the preparations for demobilization in the PNB and the FNL, as well as the resizing of the FDN.

\section{Enhancing the professionalism of the defense and security forces}

86. The government of Burundi envisages a reform of the defense and security forces in order to promote the creation of a professional and republican army in harmony with 
the population as a whole. This will entail promoting discipline, respect for human rights, and political neutrality through a deeper understanding of military leadership and international law. Training activities are currently being carried out along these lines. Two military contingents to be deployed in Somalia within the framework of the African Union's peace-keeping mission have received training to enhance their effectiveness for this kind of intervention. This was supplemented by training in human rights and the rights of the child by BINUB, UNICEF, and UNIFEM.

87. The PNB is being transformed into a local police force with the capacity to ensure the security of persons and property, while respecting republican principles and individual rights. Many training sessions on the protection of human rights and the rights of the child have been conducted by BINUB and other partner agencies such as UNICEF and UNIFEM. In addition, the PNB has been equipped with computer transmission capabilities and vehicular rolling stock. The establishment of a computer network made it possible to connect the central offices of the police force to the decentralized units and to modernize the management of the police force in the interest of greater transparency. These measures should enhance mobility and improve the coordination of police force activities, with a view to developing a concerted approach to fighting crime.

88. Activities to rehabilitate 17 military camps are in progress with a view to quartering troops. This will make it possible to attenuate the impact of their presence among the people, consolidate the integration process, and thereby lay the foundations for a genuine improvement in discipline and military professionalism. To make this rehabilitation possible, the social reintegration of the 995 displaced families living in the barracks is planned. To this end, a number of training sessions have been organized for the ex-combatants integrated into the FDN and the PNB.

89. Finally, it is important to stress that Burundi's membership in the East African Community has a positive impact from the security standpoint as illustrated by FDN participation in Tripartite Plus and the ECCAS.

\section{Disarmament of the civilian population}

90. The proliferation of light arms and small caliber weapons among the civilian population is one of the major aftereffects of the long civil war in Burundi. Various estimates agree that there are some 100,000 households in possession of light arms and small caliber weapons. The government, civil society, and the development partners are cognizant of this problem and are of the opinion that the country will not be able to restore lasting peace so long as these weapons remain in the hands of the general public. In this context, security committees have been established at the level of the communes and census districts.

91. The government has established an institutional and legal framework for disarmament, namely the National Commission for Disarmament and Combating the Proliferation of Light Weaponry. Public awareness campaigns have also been carried out by veterans' associations. The efforts made so far have made it possible to recover approximately 7.5 percent of the weapons being held illegally. At the same time, mine clearance and removal of unexploded devices are ongoing in the minefields in areas of the country where battles were waged. At present, three high-risk provinces have been 
completely cleared of mines and all the suspect zones cleaned. In addition, the people have received useful information and been sensitized to the mine problem and to how to go about protecting themselves and their children. Excavations and searches organized in one location or another are also part of the civilian disarmament program.

2.2 Promoting the rule of law, combating impunity, and promoting justice for all

92. The criticisms generally aimed at the legal institutions as a whole pertain to the low degree of judicial independence, impunity, the slowness of proceedings, the fact that the system and legislation are not in line with international standards, the lack of enforcement of rulings, corruption, inadequate training, laws that are inappropriate or full of loopholes, illegal, arbitrary, or unduly prolonged detentions, the lack of legal or judicial information and documentation, and the shortage of human and material resources.

93. The PRSP sets three objectives whose achievement cannot but have an impact on the gradual introduction of a legal system that is able to promote the foundations of the rule of law and to enhance the effectiveness of the institutions involved. These are: (i) facilitating access to justice, (ii) restoring the credibility of the legal system, and (iii) promoting and defending human rights.

\section{Facilitating access to justice}

94. The government has set itself the goals of fighting impunity and ensuring that justice is sound, swift, and effective. Bringing the legal system closer to those subject to it, unclogging court dockets, dealing with overcrowded jails and prisons, and speeding up proceedings, are additional aims.

95. A number of projects emerged in 2007: (i) the construction, rehabilitation, and outfitting of 33 Resident Courts in 8 provinces (Bubanza, Cankuzo, Cibitoke, Makamba, Muramvya, Mwaro, Rutana et Ngozi); (ii) the construction of 20 Resident Courts and the rehabilitation of 26 others, as well as their outfitting, in eight provinces (Bujumbura rural, Bujumbura Mairie, Bururi, Gitega, Karuzi, Kayanza, Makamba, Ruyigi); (iii) capacity building for court mechanisms from the ground up; and (iv) conduct of a survey of public views on the acceptable manner for judges to enforce the law.

96. The projects involving the construction and rehabilitation of court infrastructures were subject to a number of constraints related to slowness on the part of public administration units and the various government procurement procedures. The only noteworthy progress made involves the assignment of 33 lots, the preparation of technical specifications, and the signing of contracts.

97. To strengthen court mechanisms, a study was conducted on the operation of the resident courts. Two surveys were carried out, one on the manner to judge deemed acceptable by all, and the other on the perception of justice near at hand. Along the same lines, the Ministry of Justice organized a meeting with the chiefs of the grassroots jurisdictions in order to enhance their awareness of judicial ethics and the practices to be adopted. 


\section{Restoring the credibility of the legal system}

98. The government's priority is ultimately to achieve a situation in which the court system has returned to a normal pace of investigating matters before it and enforcing judicial decisions. It is of great importance gradually to reduce the occurrence of unenforced court decisions so as to prevent the people from resorting to extrajudicial means.

99. The development of a sectoral policy for 2006-2010 by the Ministry of Justice constituted a major step forward and made it possible to establish guidelines and define relevant actions likely to improve the performance of the Burundian legal system. The following options are considered priorities:

(i) Human and material capacity building in the courts and tribunals to guarantee the rapid examination and/or enforcement of court decisions, especially as regards cases involving minors in conflict with the law;

(ii) Visits on-site in order to inform the beneficiaries of court decisions of their rights and to overcome delays in resolving cases in progress;

(iii)The establishment of specialized legal structures, in particular for minors in conflict with the law, for combating violence against families, especially women and children, and for corruption;

(iv) The promotion of equity between men and women and of ethnic balance in the Burundian legal sector;

(v) Improved knowledge and application of the law through the republication of codes and laws, the harmonization of the legislative and regulatory texts, and their translation into Kirundi;

(vi) Reform of the justice sector;

(vii) Creation of a Training and Retraining Center for staff in the judicial sector, and improving the working conditions and status of judges;

(viii) Strengthening the fight against corruption and impunity, and improving working conditions in the judicial sector;

(ix)Enforcement of rulings on land tenure disputes;

(x) Strengthening the mechanisms for arbitration and legal solutions close at hand;

(xi)Eliminating jail and prison overcrowding, and separating children from adults and women from men.

100. It was found that most of the activities envisaged did not truly get underway in 2007. However, the preparatory work is drawing to a close, so there is reason to hope that they will effectively begin in the course of 2008.

\section{Promoting and defending human rights}

101. Despite the efforts and some progress made as regards defending human rights, the situation remains one of concern. To remedy this, a number of information and sensitization workshops on the basic principles of human rights and the rights of the child were organized for the general public and the police force by the government, BINUB, and local and international NGOs. Along the same lines, the Ministry of Defense organized a seminar for officers on humanitarian rights and the law of war. 
102. A National Independent Human Rights Commission (CNIDH) charged with promoting and protecting human rights is currently in the preparation phase. Through its educational and observational activities, and through its opinions and recommendations, this institution will contribute to enhancing the awareness of the various stakeholders as regards responsibilities and duties in terms of respect for human rights. The active participation of this institution in the resolution of cases in which human rights have been violated will have a genuine impact on the consolidation of peace in Burundi.

103. Noteworthy among the progress made with consolidation of the rule of law are: (i) the framework agreement signed by the government and the United Nations on the implementation of transitional justice mechanisms; (ii) the establishment of a tripartite committee, officially launched on November 2, 2007, including representatives of the government, the United Nations, and civil society and charged with organizing national consultations on transitional justice in Burundi; (iii) the organization of regional information workshops on the CNIDH; and (iv) approval by the United Nations of the project supporting national consultations within the framework of the transitional justice system.

104. The resurgence and spread of sexual violence, the persistent slowness in the processing of cases related to human rights violations, the absence of special measures for the protection of children within the justice system, and the difficulties experienced in beginning the consultations with the public, remain major challenges to be met in order genuinely to establish the rule of law. In addition, the implementation of transitional justice and an in-depth reform of the justice sector are urgently needed.

2.3 Resolving the risks of conflicts associated with land tenure / Sustainable management of land tenure conflicts

105. The land tenure issue is acute, and is worsened by the return of repatriated and displaced persons to their places of origin. To address this, the PRSP recommends the implementation of three programs focused on: (i) taking the land tenure dimension into account in the management of conflicts; (ii) the greatest possible equity in the management of government land holdings; and (iii) strengthening of the mechanisms for conflict resolution and prevention.

\section{Taking the land tenure dimension into account in conflict management}

106. The majority of the problems recorded in Burundi's legal jurisdictions are land tenure problems. According to the results of the 2007 survey on the traceability of public expenditure in the justice, education, and health sectors, they account for approximately 94.4 percent of all cases. Listings of the matters before the various jurisdictions also show the predominance of land tenure issues, as shown by the data in Table 5 .. 
Table 5: Land tenure problems recorded in matters before the courts

\begin{tabular}{|l|c|}
\hline Jurisdiction level & $\begin{array}{l}\text { Land tenure problems in the matters before the } \\
\text { jurisdiction (percent) }\end{array}$ \\
\hline Appeals court/Administrative court & 71.4 \\
\hline Court of High Instance & 52.4 \\
\hline Labor/Commercial Tribunal & 33.3 \\
\hline Residential Tribunal & 59.5 \\
\hline Overall & $\mathbf{5 6 . 3}$ \\
\hline
\end{tabular}

Source: ISTEEBU, PETS-2008 Survey.

107. These land tenure problems, which often involve opposing families or neighboring populations, are genuine hotbeds of tension, and even of violent conflicts which can degenerate into fatal brawls, as the local media have reported in abundance over the past few years. The government is conscious of the urgent need to take the first steps toward finding sustainable solutions to the risks of tensions associated with the land tenure issue in the country. Prevention at the grassroots constitutes the approach of choice to this end. The regular court system is already overloaded, slowed down by cumbersome procedures. The settlement of land tenure conflicts by alternate mechanisms, civil society bodies, commune-level elected officials, or Bashingantahe, wise men who follow the local customs and reconciliation practices, and the National Commission on Land and Other Assets, plays an important role in the maintenance of social peace.

\section{Greater equity in the management of the land patrimony}

108. A survey conducted in December 2007 revealed the existence of 16,429 hectares of unused land, 30,896 hectares of unlawfully allocated land, and 110,961 hectares of sequestered land. Verification of the land award documents is in progress, and could confirm the accuracy of the data provided by the survey.

109. In 2007, the UNDP financed and coordinated an international study mission on the land tenure issue and alternative solutions to reintegration challenges. This study points toward possible solutions: (i) clear affirmation of the state's political will to manage the land tenure question and the establishment of a participatory process for drawing up the land tenure policy; (ii) the promotion of land tenure governance and the modernization of the land tenure administration; (iii) support for management/conflict resolution mechanisms, in particular for making land tenure secure; and (iv) equity in land distribution.

110. The land code of 1986 remains in force, with its sizable omissions and its provisions that lend themselves to varying interpretations. The establishment of the Expanded Interministerial Technical Committee for the drafting of a land tenure policy and revision of the land code will make it possible to adapt the code to the prevailing problems. Moreover, the financing of land tenure security projects at the provincial level within the framework of decentralization is conducive to adapting land tenure administrative procedures to the realities of illiteracy and poverty among the rural population. 
111. Because the draft law on successions, gifts, and matrimonial systems has still not been adopted, women continue to have problems accessing land. However, following the successive crises, the number of female heads of household is high. Orphaned children or heads of household also lack access to a justice system that guarantees their full defense and the enforcement of application of their succession rights.

\section{Strengthening of conflict prevention and resolution mechanisms}

112. The alternative mechanisms for the resolution of land tenure conflicts through civil society organizations, the Bashingantahe, or the CNTB are supportive of mediation and peaceful resolutions. The disputes thus resolved by consensual, rapid justice that is near at hand also contribute to easing the crammed dockets of the traditional courts.

113. Establishment of the interministerial commission on agrarian reform could make it possible to clarify conflicts relating to ministerial jurisdictions. The 23 members on the central level of the National Commission on Land and Other Assets (CNTB) have the authority only to ratify solutions proposed or decisions reached by the parties, which to this extent limits the capacity of the Commission to close out matters that have been examined fully. What is more, the fact that judges, in particular those of the Court of High Instance, are part of the provincial reconciliation commissions, constitutes a major handicap as regards their impartiality when one of the plaintiffs decides to institute legal proceedings. Finally, settlements are slowed down by the lengthiness of court proceedings and the absence of a mechanism near at hand that is simplified and specialized in land tenure disputes.

\subsection{Promoting good governance}

\section{Promoting political governance}

114. The specific objectives pursued in the political governance context are aimed at (i) building the capacities of elected bodies; (ii) promoting decentralization and enhancing citizen participation; (iii) strengthening the reporting requirements of government officials and elected officials; and (iv) adapting the electoral systems to sociopolitical developments

\section{Building the capacities of elected bodies}

115. A number of training sessions were organized for members of Parliament and local elected officials and individuals on accounts management, good governance, human rights, transitional justice, and peaceful conflict resolution. Similarly, most members of commune-level councils and commune-level administrators received training on governance and decentralization. The Senate organized visits to the provinces to have exchanges with local elected officials on decentralization and the possibility of creating an association of local elected officials throughout the entire country.

116. After assessing the needs and constraints affecting commune-level authorities in terms of working tools and logistical resources, a manual on financial and administrative management was prepared along with a national guide on commune-level planning. Following a joint effort by the World Bank, the United Nations, and the European Union, 
70 commune level offices were built in the course of 2007. Other training tools are being developed within the communes, with emphasis on tools for project coordination and administrative and financial management. With regard to logistical capacity building, financial support from IFC made it possible to provide office furniture to the communes, while the government made transportation equipment available.

\section{Promoting decentralization and building citizen participation}

117. Several activities were organized in connection with promoting decentralization and citizen participation policy. A national policy letter on decentralization and community development was drafted and adopted by the Council of Ministers. This document establishes an outline institutional framework for the decentralization policy and delineates the Burundian vision of community development.

118. As a prelude to the organization of the states general on decentralization to be held in 2008, a study taking stock of progress with decentralization was prepared. The study identified four axes, namely: (i) the legal framework; (ii) the institutional structure; (iii) financing mechanisms; and (iv) accountability and appointment modalities. The latter makes reference to the basic information needed for preparing the National Decentralization Policy Paper. The clearly established objective of holding the states general is to ensure the maximum citizen participation in the process of preparing the national decentralization policy paper.

119. The National Decentralization Policy Paper (DCPND) and the Three-Year Action Plan (PAT) for the implementation of decentralization are the deliverables anticipated from these states general. The DCPND will define the major strategic directions of the decentralization policy and the actions to be envisaged for the long term ( 8 to 10 years). In contrast, the PAT will be a decentralization policy implementation tool for the short term ( 3 years). To that end, all NGOs will be invited to focus, in their interventions, on the priority actions identified within the framework of the commune-level plans. Their geographical placement will be dictated by the equity that will need to be established among the various provinces of the country.

120. It must be acknowledged, however, that technical capacities are somewhat limited at the commune level. Of necessity, decentralization will have to be accommodated by deconcentration in order to build enhance skills at the local levels. Moreover, the national communal investment fund established by the government has been designed to support the communes' priority projects. The fund now needs to be allocated sufficient financial resources sufficient to fully carry out its missions.

\section{Strengthening the reporting requirements of government leaders and elected officials}

121. The law on communes currently in force calls for two meetings a year to take stock of activities. These meetings are open to the local councils and to representatives of the associations working in the commune. At these meetings, the communal authority reports to the people on the political, social, and economic situation prevailing in the commune. Participants can propose solutions to be adopted and policy approach to be followed. In the event, this provision has not been strictly observed as regards the frequency of meetings and the contents of the messages. For this reason, a sustained 
awareness campaign aimed both at elected officials and the general public is needed to ensure that this stakeholder consultation is effective.

\section{Adapting electoral systems to sociopolitical developments}

122. The electoral system (blocked list) does not require that leaders be accountable to the voters. Accordingly, the reforms to be considered should increase competition and introduce a system of sanctions to clearly lay out a line of accountability.

\section{Promoting efficient public administration}

123. Meeting this objective is based on the following actions: (i) bolstering the organizational capacities of public administration; (ii) bringing public services closer to users; and (iii) reducing labor conflicts within public administration.

\section{Bolstering the organizational capacities of public administration}

124. Creation of the National School of Administration (ENA) is part and parcel of the programs to build the capacities of the institutions and structures of public administration. During the first phase, the activities carried out related to bringing on staff and preparing training programs.

125. The National Employment and Training Observatory (ONEF) has been established with a view to building capacities for gathering, processing, and analyzing statistical data on the labor and job markets. This structure makes it possible to revitalize the unit in charge of statistics in the Ministry of Civil Service, Labor, and Social Security, to provide staff training, and to furnish work material.

\section{Bringing public services closer to users}

126. The government initiated a National Decentralization Plan with the aim of bringing public services closer to users and thereby facilitating user participation in decision-making on development issues. Within this framework, the delocalization and deconcentration process for public services is ongoing. The provincial offices of the Civil Service are already operational in Ngozi, Gitega, and Bururi Provinces. In addition, the labor administration has opened the Gitega and Ngozi office, while the INSS and the Civil Service Mutual Association have remote offices in the majority of the provinces. The INSS is already providing pension services in the administrative seats of the communes.

\section{Reducing labor conflicts within public administration}

127. The government has always sought to maintain dialogue with the workers' trade union representatives so as to preserve a sound labor/management climate. A permanent framework for dialogue between the civil service trade unions and the government has therefore been established. The work program defined to this end is consistent with the action plan prepared. It is aimed at building the capacities of labor and management in 
order to revitalize the social dialogue frameworks essential for underpinning peace in the world.

\section{Promoting economic governance}

\section{Creating an institutional and legal environment conducive to good governance}

128. Anxious to stymie the phenomenon of corruption, the government of Burundi has already taken some legislative initiatives. These concern: (i) revision of the code of the court organization and jurisdiction of March 17, 2005; (ii) promulgation of Law No. 1/12 of April 18, 2006 providing measures to prevent and combat corruption and related offenses; (iii) promulgation of Law No.1/27 of August 3, 2006, on the creation, organization, and operation of the Special Anti-Corruption Brigade; (iv) signing of Decree No.100/339 of November 13, 2006, creating regional offices of the Special AntiCorruption Brigade; and (v) creation of the Anti-Corruption Brigade.

129. The Special Anti-Corruption Brigade began its activities in the second half of March 2007. The Brigade and the Anti-Corruption Court received vehicles, computer hardware, and training in auditing, accounting, and procurement. Exchanges of experiences were also organized in South Africa. The major handicap for the AntiCorruption Brigade relates to the fact that the eight police stations that were to be established in the country have not been owing to the shortage of financial and material resources. Since beginning activity in March 2007, it has been able to investigate and forward 18 violation reports to the general prosecutor's office with the Anti-Corruption Court and the prosecutor's office of Gitega. These 18 cases represented damages of $\mathrm{FBu} 375,930,441$ to the Public Treasury. Of this amount, FBu 119,554,189 has been recovered for the Treasury.

130. In early 2007, the State Inspectorate General was staffed by only 17 inspectors charged with responding to various requests as regards supervision. In June 2007, 53 new inspectors were recruited, increasing the staffing level to 70. In 2007, the State Inspectorate General was able to produce 54 reports and 38 memoranda. It is the followup to these reports and memoranda, which are of high quality that must be strengthened. Action to carry out recommendations and the application of administrative or penal sanctions are always very slow, when steps are taken at all.

\section{Rehabilitating the management of public finances and government procurement}

131. Specific measures aimed at increasing the national capacities to generate more public revenue had been identified during PRSP preparation. They were primarily aimed at (i) extending taxation to activities that were still falling outside the tax system in order to achieve an system of taxation at profitable tax rates; (ii) reducing the tax and customs exemptions; (iii) improving the effectiveness of tax and customs administration; (iv) improving taxpayer identification by adopting a Single Identifier System; and (v) preparing and introducing a Value-Added Tax (VAT) system and creating a Revenue Office to enhance performance.

132. These reforms are part of the dynamics of Burundi's integration into regional bodies such as the East African Community (EAC). The adoption of a new customs code, 
the initial implementation of the action plan to strengthen the Customs Directorate, and the conduct of impact studies relating to application of the Common External Tariff are the main programs initiated in the search for greater customs system efficiency.

133. At the same time, significant advances were made as regards preparation of the General Tax Code, the Code of Tax Procedures, and the Taxpayer Charter, the budgetary and economic impact study on Burundi's entry into the EAC, the preparation of legal provisions on introduction of the VAT, and the application of information technology which know allows for securitized monitoring of collections.

134. Steps have been taken to streamline indirect taxation and tax exemptions. To this end, the 2008 budget law 2008 incorporates: (i) the introduction of the tax on cable television; (ii) the creation of a hotel and tourism tax; (iii) elimination of the transaction tax on real property transfers; and (iv) the reduction of the transfer taxes on the real property sales from 6 percent to 3 percent. The reform program should ultimately be consolidated, with the twofold objective of improving the tax revenue collection systems so as to ensure successful integration into the EAC, and increasing the national resources directed toward reducing To this end, it will be necessary to: (i) accelerate the procedures for introducing the VAT, adopting the Common External Tariff, and creating the Revenue Office; (ii) modernize the units responsible for customs and taxes, in particular by means of a suitable adapted information technology system, while ensuring effective coordination between them; and (iii) take the measures necessary to broaden the tax base.

135. Prudent management of the budget, the wage bill, and transparency represent essential aspects of the government's policy, which has already led to new measures focused on sound control and efficient management of public expenditure. These measures focus primarily on: (i) limiting compensation through the demobilization program; (ii) streamlining state personnel management, including the launch of the physical census of civil servants and the transfer of payroll management to the Ministry of Finance; (iii) introducing an Integrated Financial Management Information System; and (iv) establishing a cash flow plan to improve cash management. These measures constitute important steps forward.

136. Revision of the organic law will have a genuine impact on the effectiveness of public finance management. It will be strengthened by laws and regulations on government accounting, supervision, and auditing, as well as on the procedures for preparing and submitting draft budget laws. The conduct of audits on the cross-debts between the government and the oil companies and on the use of the resources made available under the HIPC Initiative demonstrate the government's resolve to consolidate the principles of observing transparency in public finance management. Implementation of the action plans recommended by these two audits will make it possible to correct any errors found and avoid them in the future.

\section{Improving the steering of economic policies}

137. The revision of the INPLABU model made it possible to fine-tune an application that should not only be of value for planning and forecasting, but also economic and social impact analysis. The macroeconomic modeling team established for this purpose should receive appropriate support in order to become genuinely operational. 


\section{Streamlining the management of public enterprises}

138. The SCEP has worked out a program for SPPs over the 2006-2007 period which places particular emphasis on the privatization of the following companies: Air Burundi, the Public Slaughterhouse of Bujumbura, COGERCO, COTEBU, OCIBU, ONATEL, ONAPHA, OPHAVET, OTB, REGIDESO, the Source du Nil hotel, SIP, SOSUMO, ALM, LNBTP, SOCABU, UCAR, and SBF. The reforms based on state divestment of its interest in the productive sectors date back to 1986. Nevertheless, the results remain insufficient. For 2007, appraisals were completed for an insurance company (UCAR), a sugar company (SOSUMO), a development bank (SBF) and a slaughterhouse (APB). Invitations to tender were launched for the sale of the state's shares in OCIBU and BCC. The government is searching for a strategic partner for COTEBU. The privatization law has been revised to allow for the state's rational disengagement from the productive sectors.

Strengthening the institutional structures for the internal and external control of the fight against corruption

139. Internal control systems have been introduced at the Ministry of Finance and directives issued to ensure that such arrangements are extended to all ministries. The Audit Court completed the task of auditing the 2007 accounts, and the members of the Finance Committees of the two chambers of Parliament attended training sessions on the budgeting process and on procurement procedures.

\section{Strengthening the role of civil society in the economic governance of the state}

140. Through certain consumers' associations and/or anti-corruption groups, civil society, not to mention media criticism, voices have been raised to denounce economic embezzlement or acts of poor governance. The government is endeavoring to strengthen a genuine partnership with society for a concerted and effective fight against financial embezzlement.

\section{PROMOTION OF SUSTAINABLE AND EQUITABLE ECONOMIC GROWTH}

3.1 Revitalization of agriculture, livestock farming, fisheries, and fish farming

141. Economic growth in Burundi is driven primarily by: (i) the revitalization of food crop and export crop production; (ii) the development of livestock production; (iii) the development of bee-keeping and fisheries; and (iv) the revival of fish farming.

Revitalization of food crop and export crop production

\section{Food crops}

142. Total food crop production increased between 2006 and 2007. Estimated production for these years rose from 3,641 thousand to 3,756 thousand metric tons, 
respectively, for an increase of 3.0 percent (see Table 6). This growth rate is virtually the same as the population growth rate, estimated at 2.9 percent per annum. The improvement in food production is attributable to satisfactory rainfall and to a number of actions taken to revitalize the food sector. These include in particular the public awareness campaigns, the strengthening of extension services, and the broad dissemination of strains of more disease-resistant crops (manioc cuttings tolerant to severe mosaic virus). Other critical actions involved the production of seeds (high quality rice and sorghum), marsh management (350 ha), and the construction of community storage infrastructures. In addition, vulnerable households benefited from assistance in respect of key crops $(80,000$ fruit tree seedlings, more than 14 million sweet potato cuttings, 10 metric tons of groundnut seeds, and the return to taro raising).

143. Despite these revitalization efforts, structural constraints slowed the real increase in food production. Among the deplorable constraints are the weak intensification of production, the scattered layout of cultivable land, poor water management, and the problems of post-harvest conservation and processing. The foregoing was compounded by farmers' poor access to credit and the lack of competitiveness of many agricultural products. Lastly, the extension services and the coordination of interventions in the agricultural sector are insufficient and inadequate. The trends indicated in following table illustrate the problems experienced by the agricultural sector in generating a significant surplus making it possible to satisfy the food requirements of the population. 
Table 6: Trend of food crop production in Burundi (in thousands of metric tons)

\begin{tabular}{|l|c|c|c|c|c|c|c|c|}
\hline & $\mathbf{1 9 8 8 - 9 3}$ & $\mathbf{2 0 0 4}$ & $\mathbf{2 0 0 5}$ & $\mathbf{2 0 0 6}$ & $\mathbf{2 0 0 7}$ & $\mathbf{2 0 0 8}$ & \multicolumn{2}{|c|}{ Change } \\
\hline & (Avg.) & & & & & (Proj.) & $\begin{array}{c}2008 \\
/ 2007\end{array}$ & $\begin{array}{c}2008 \\
/ 88-93\end{array}$ \\
\hline Cereals & 298 & 280 & 290 & 282 & 290 & 289 & -0.3 & -3.0 \\
\hline Legumes & 369 & 252 & 250 & 238 & 239 & 232 & -2.9 & -37.1 \\
\hline Roots and tubers & 1,433 & 1,649 & 1,575 & 1,458 & 1,518 & 1,573 & 3.6 & 9.8 \\
\hline $\begin{array}{l}\text { Bananas and } \\
\text { plantains }\end{array}$ & 1,563 & 1,590 & 1,636 & 1,663 & 1,709 & 1,779 & 4.1 & 13.8 \\
\hline & & & & & & & & \\
\hline Total (1) & 3,663 & 3,771 & 3,751 & 3,641 & 3,756 & 3,873 & 3.1 & 5.7 \\
\hline & & & & & & & & \\
\hline Growth (percent) & - & 2.9 & -0.5 & -2.9 & 3.2 & 3.1 & -1.4 & - \\
\hline Population (2) & $5,743,247$ & $7,565,782$ & $7,858,791$ & $8,173,070$ & $8,062,413$ & $8,275,166$ & 2.6 & 44.1 \\
\hline $1,000 *(1) /(2)$ & 0.64 & 0.50 & 0.48 & 0.45 & 0.47 & 0.47 & 0.5 & -26.6 \\
\hline
\end{tabular}

Sources: FAO, MINAGRI, and Word Development Indicators.

144. Specific actions were launched to support the policy of revitalizing food crop production in 2007. First was the issue of introducing a monitoring and evaluation system. This initiative led to the organization of the National Forum on the States General of Agriculture and Livestock for Sustainable Food Security in Burundi. The government also supported the creation of a high-performance system for the efficient monitoring and evaluation of the National Food Security and Rural Development Policy. An inventory of greenhouse gases was conducted at the same time as the upgrading of the Multimedia Center. More specifically, the bolstering of agronomical research (CNTA) and the training and of supervisors and staff in key areas (software usage and the control of standards and quality) contributed to the modernization of the agricultural production system. Second, extension services were improved thanks to recruitment of agricultural monitors for the provinces of Bubanza, Kayanza, Karusi, Muramvya, Mwaro, Ngozi, Gitega, and Cibitoke. Training was provided in the provinces of Bubanza, Cibitoke, Karusi, Kayanza, Kirundo, Muyinga, Mwaro, and Ngozi. The strengthened agricultural extension effort was tangibly reflected in the assignment of the agronomical monitors in every commune and census district. However, the effectiveness of these agronomical monitors is reduced by the absence of any specific activity program, inadequate supervision of the hierarchy, and the lack of motivation.

145. The promotion of agricultural inputs was intensified in order to better support the revival of food production. To increase access to these inputs, the following actions were accorded priority: (i) the rehabilitation and upgrading of the Seed Centers in 15 DPAEs; (ii) rapid multiplication and distribution of healthy manioc stock; (iii) support for and revitalization of the seed sector in Burundi; (iv) laboratory quality control of seed; (v) the survey on the importation, consumption and/or sale of pesticides; (vi) the introduction of rootstocks of citrus fruits and mango trees; (vii) maintenance of the timber yard and the gathering of plant and agricultural material; and (viii) the production of improved seeds.

146. The first year of PRSP implementation also featured continuation of the irrigation program. One notable action was the granting of 280 pedal pumps which facilitated the 
irrigation of the Lacs du Nord marshes in Kirundo Province. They also made it possible to irrigate 158 hectares and to rehabilitate the Murambi channel and the Rugombo irrigation network. In addition, the irrigation program made it possible to lay out a new 3 km long channel in Kirundo.

147. Despite an overall increase in production in 2007, the food security of Burundi's rural population remained dangerously precarious, largely owing to the sharp decline in the production of leguminous plants ( -37 percent), dominated by dry beans. This foodstuff is the major source of plant protein in the country. Moreover, the increasing dependence of households on the marketplace for their food is one of the stark realities of 2007. This confirms the insufficiency of harvests for covering the food requirements of the population and demonstrates the limits of Burundi's agricultural system, which is focused primarily on food crops. In addition, the surge in food product prices, which became more pronounced in 2007, further complicated the nutritional situation, in particular for low-income households.

148. Sustained growth in food crop production is thus a vital objective to be achieved rapidly. This makes it a pressing need to implement a cohesive policy on water control and management. The identification of the actions to be adopted for such a policy effectively to be carried out is of quite particular importance. At the same time, the increased farm yields thanks to the regular provision of quality inputs are a priority that is essential for the restoration of food equilibrium. Moreover, it is fundamental to preserve the gains made by existing development projects in order to forestall the possibility that their completion not result in the loss of accumulated skills. In addition, the continuation of research programs is to be encouraged in the interest of continuous improvement in yields from the land. Accordingly, there must be more rapid soil fertilization efforts, improved climatological knowledge, and on-time availability of selected seeds.

\section{Export crops}

149. As regards export crops, the reforms being prepared pursue three major goals: quality improvement, higher producer prices, and opening to competition so as to promote greater competitiveness. Similarly, the introduction of a program to diversify exportable products is imperative. With regard to the results observed, 8,000 metric tons of commercial coffee was produced in crop year 2007/2008. The optimistic estimates for crop year 2008/2009 are for the production of 30,000 metric tons, an increase explained in principle by cyclical phenomena. This said, it should also be recognized that extension services were improved and that public awareness of plantation maintenance was intensified.

150. The enlargement of coffee plantations is one of the preconditions for the revitalization of coffee production. To this end, the process of privatizing the production tools, already underway, has just been resumed by completely opening marketing to competition. Moreover, a strategy for selling coffee washing stations has been launched and should enable the government to identify the best option for ensuring the sustainability of the subsector and guaranteeing a profitable price to coffee growers. By conveying its shares to the private sector, the state will ultimately focus activities on 
regulation of the subsector. To facilitate this transition, the following tasks have been carried out: (i) a diagnostic study on the competitiveness of the subsector; (ii) a study on pilot stations for the production of specialty coffees; (iii) formulation of a communications strategy; (iv) a study on the prevention of risks of conflict; and (v) an audit of coffee crop years 2004/05 and 2005/06.

151. Major advances have also been made as regards preparing the regulation on coffee sales, which establishes full competition in coffee sale operations. This competition also applies to coffee growers' associations, which play an active role in defending producer prices. The reforms deregulating the enterprises have already borne fruit, as the producer price has continually improved. The price of berries thus increased from $\mathrm{FBu} 150$ in crop year 2005/2006 to FBu 300 for crop year 2007/2008. It is nevertheless essential that the government find a sustainable solution to the problem of cyclical swings in coffee production so as to stabilize and increase yields.

152. For tea, production in 2007 came to 6,858 metric tons of dry tea against forecasts of 7,300 metric tons. The target was thus 94 percent met. The forecast levels were not met at all production units following the prolonged rainfall stoppage and an obvious nutritional deficiency after more than three years without the application of fertilizer. However, 2007 production did increase by 8 percent over the 2006 level. At the same time, the producer price has been stagnant at FBu 100/kg of green leaf since 2003.

153. The government has initiated a recovery program for the tea sector. This program, which is part of the sector reform strategy, calls for deregulation, opening to the private sector, and gradual divestment by the state. Among noteworthy achievements, it should be noted first that a tea subsector reform committee has been created and an action plan adopted to serve as a roadmap. The reform of this intricately interconnected subsector, it bears recalling, includes: (i) reorganization of the OTB and deregulation of the production apparatus; (ii) privatization of the subsector and increased competitiveness of the tea industry; (iii) rehabilitation of the production apparatus and the addressing of energy issues; and (iv) capacity building of stakeholders and the establishment of a communications campaign. Next, it is important to note a study on enhancing the competitiveness of the tea industry conducted in 2007. In addition, the final reports on additional studies are being finalized, namely the reports on the accounting and financial audit and the correction of OTB accounts (2005 and 2006), on the analysis of the OTB's internal control system, and on the technical and financial audit and the diagnostic study on the prevention of conflict risks in the tea subsector reform process in Burundi.

154. Cotton production in 2007 was 6 percent lower than in $2006(2,870$ metric tons as against 3,037 metric tons). The cotton production forecasts for 2008 are estimated at 3,500 metric tons following the various actions adopted by the Cotton Management Company (COGERCO) in 2007. Among the most important of these measures are the expansion of sown areas (4,500 hectares in 2008 compared to 3,905 hectares in 2007), the raising of producer prices (from FBu 200 to $\mathrm{FBu} 230$ per kilogram), the awarding of bonuses to the best producers and extension personnel, and the establishment of a credit facility for the purchase of fertilizers and plates.

155. In the case of palm oil production, there was a downward trend, with a reduction of 7 percent in 2007 compared to 2006 levels (12,773 metric tons as compared to 13,771 
metric tons). This decline in is primarily attributable to the aging of the palm plantations but also to the cyclical swing phenomenon. Among the more notable actions to be cited are the establishments of new nurseries by the palm growers supported by PRASAB. These nurseries seedbeds will make it possible to revitalize oil production thanks to the planting of a new 3,000 hectare palm plantation. The European Union and IFAD are also active in the program to revitalize palm growing through the STABEX project and the PTRPC. The producer price, which ranged between FBu 600 and FBu 880 per liter in 2006, remained at the same level for 2007.

156. The export diversification policy is at the heart of the strategy to increase export volumes, but has not yet had the desired impacts (see Table 7). However, progress is apparent at the level of trade flows in fish, live animals, raw hides, and flower and fruitbearing products. The poorer than anticipated results are reflected in the inertia of the export structure, where the lion's share continues to be accounted for by traditional crops, with coffee alone accounting for more than 68 percent of total exports at end-2007. To identify new export opportunities, studies were conducted in 2007 on the competitiveness of the sugar subsector and of flower and fruit-bearing products.

Table 7: Export structure (in millions of Burundi francs)

\begin{tabular}{|l|c|c|c|c|c|c|c|c|}
\hline \multirow{2}{*}{ Goods } & \multicolumn{2}{|c|}{$\mathbf{2 0 0 4}$} & \multicolumn{2}{c|}{$\mathbf{2 0 0 5}$} & \multicolumn{2}{c|}{$\mathbf{2 0 0 6}$} & \multicolumn{2}{c|}{2007} \\
\cline { 2 - 9 } & percent & value & percent & value & percent & value & percent & value \\
\hline $\begin{array}{l}\text { Primary } \\
\text { commodities }\end{array}$ & 86.8 & $45,751.6$ & 91.1 & $57,132.2$ & 95.8 & $57,846.6$ & 95 & $51,203.4$ \\
\hline $\begin{array}{l}\text { Commercial } \\
\text { coffee }\end{array}$ & 61.4 & $32,341.6$ & 69.5 & $43,586.6$ & 67.7 & $40,838.2$ & 68,2 & $32,656.8$ \\
\hline Cotton & - & - & 3.1 & $1,919.4$ & 2.0 & $1,211.2$ & 2,7 & $1,470.2$ \\
\hline Raw hides & 0.5 & 284.8 & 0.7 & 458.8 & 2.6 & $1,574.3$ & 5,5 & $3,823.6$ \\
\hline Tea & 21.3 & $11,245.8$ & 15.2 & $9,564.8$ & 17 & $10,238.4$ & 14,4 & $9,924.5$ \\
\hline $\begin{array}{l}\text { Manufactured } \\
\text { goods }\end{array}$ & 13.2 & 6,937 & 8.9 & $5,605.5$ & 4.2 & 2,513 & 5 & $3,422.4$ \\
\hline Total & $\mathbf{1 0 0}$ & $\mathbf{5 2 , 6 8 8 . 6}$ & $\mathbf{1 0 0}$ & $\mathbf{6 2 , 7 3 7 . 7}$ & $\mathbf{1 0 0}$ & $\mathbf{6 0 , 3 5 9 . 6}$ & $\mathbf{1 0 0}$ & $\mathbf{5 4 , 6 2 5 . 8}$ \\
\hline
\end{tabular}

\section{Development of livestock production}

157. To reconstitute food production capacities, the efforts currently underway concentrate on promoting short-cycle livestock farming and on increasing cattle raising (see Chart 3 below). The government and donors thus hope to increase the consumption of animal protein while improving incomes, involving the new arrivals in agriculture, and to improving relations between social groups. Moreover, in addition to beneficial effects on the environment, this active policy, which integrates women into development, has positive consequences in terms of poverty reduction. In fact, the repopulation and livestock development programs must take account of the dwindling possibilities for grazing. A reorientation toward a system of feedlot fattening is becoming more and more essential.

158. There are two kinds of efforts being made to rebuild food production capacities. On the one hand, four specific actions are being taken with respect to short-cycle 
livestock and cattle rearing, namely: (i) the promotion of short-cycle livestock farming (benefiting groups of stockbreeders) which yields rapid results; (ii) support for cattle breeding using artificial insemination; (iii) the practice of cross-breeding with improved stock; and (iv) building the capacities of stockbreeder groups through direct grants of animals. In addition, actions to rebuild herds of large and small cattle were carried out. These included the Agricultural Rehabilitation and Sustainable Land Management Project (PRASAB), the Transitional Post-Conflict Rehabilitation Program (PTRPC), the Program to Revive the Rural Environment (PRDMR), the Program for the Rehabilitation of Disaster Victims and Poverty Reduction (PRRSLP/UNDP), the Bututsi Project, and several highly active NGOs. For its part, the government allocated FBu100 million against I-HIPC funds to restart the Gitega poultry farming project. The latter activities are also supported by the Project to Support the Rebuilding of the Livestock Sector (PARSE).

159. For large cattle, the government's aim is to improve local cattle through crossbreeding with highly productive sires. In this connection, the importation of semen for artificial insemination is already producing better results than the importation of animals that are poorly adapted to climatic conditions in Burundi. Breeding centers have been installed and turned over to management by communities previously trained by the veterinarians of the extension services. Various interventions made it possible to consolidate the efforts aimed at rebuilding the cattle herd, rehabilitation of veterinary infrastructures and care, and the provision of veterinary inputs.

Chart 3: Herd size trend

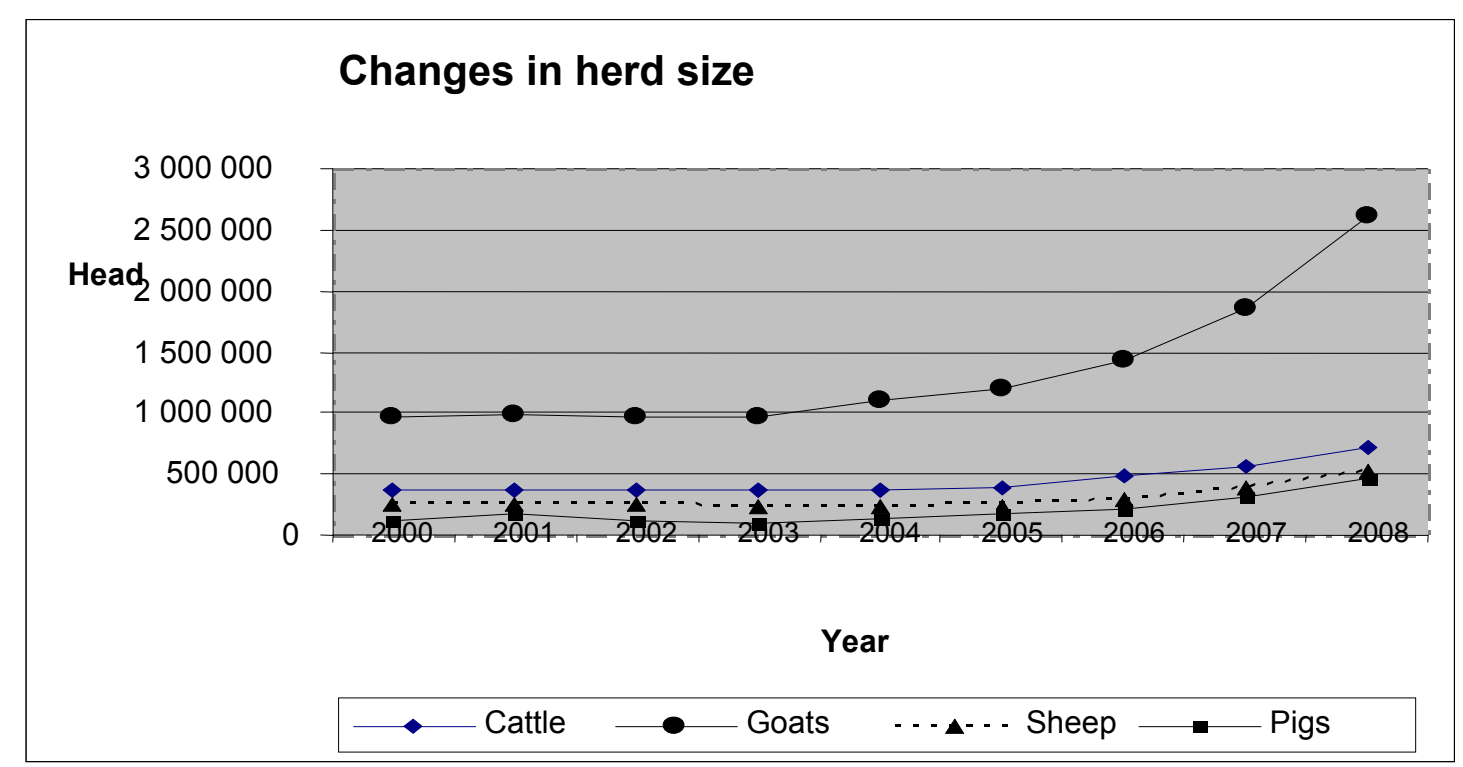

Sources: FAO and MINAGRI.

160. In the case of small cattle, in 2007 the FAO distributed goats and kits with veterinary products and equipment to over 5,925 vulnerable households. The specific actions carried out to promote small cattle rearing concerned: (i) the relaunching of the Gitega poultry farming center; (ii) the prevention and control of avian flu; and (iii) improved veterinary services. The results of these actions the rapid rebuilding of the cattle, goat, sheep, and pig populations. However, the earlier experimentation with dairy 
goat varieties in Ngozi Province was not used and developed adequately. However, these varieties seem to be best adapted to the majority of provinces where grazing areas are shrinking at a great rate. Still as regards small animal rearing, it is worthwhile to stress that the promotion of bee-keeping has also been undertaken in Ngozi, Cibitoke and Karusi Provinces under PRASAB and PRDMR. Similarly, herd management techniques, especially the permanent stabling of large cattle, pigs, and poultry, will make it possible to put harvest waste products to good use.

\section{Development of fisheries and revitalization of fish farming}

161. National fish production showed no improvement, and the production of 11,500 metric in 2007 fell short of the forecast of 14,407 tons. Compared to 2006, performance was down by 18 percent. This significant drop is attributable mainly to: (i) the use of prohibited nets prohibited ("mosquito net") for the capture of fry; (ii) excessive and anarchistic farming of the wetlands along the lakeshores; and (iii) hyacinth pollution of the water, destroying spawning areas. Table 8 shows a downward trend in fish production and highlights the low proportion of industrial fishing, which accounts for only 17 percent.

Table 8: Changes in fish production, 1998-2007 (in kilograms)

\begin{tabular}{|l|c|c|c|c|}
\hline YEAR & $\begin{array}{c}\text { TRADITIONAL } \\
\text { FISHING ALL } \\
\text { TYPES }\end{array}$ & $\begin{array}{c}\text { NONINDUSTRIAL } \\
\text { FISHERIES }\end{array}$ & $\begin{array}{c}\text { INDUSTRIAL } \\
\text { FISHERIES }\end{array}$ & TOTAL \\
\hline 2000 & 458,133 & $16,365,449$ & 55,230 & $16,878,812$ \\
\hline 2001 & $1,062,016$ & $9,010,604$ & 96,700 & $10,169,320$ \\
\hline 2002 & 986,996 & $13,050,922$ & 138,363 & $14,176,281$ \\
\hline 2003 & 677,607 & $12,737,453$ & 292,499 & $13,707,559$ \\
\hline 2004 & 605,057 & $12,683,885$ & 225,789 & $13,514,731$ \\
\hline 2005 & 696,698 & $8,703,955$ & 204,224 & $9,604,877$ \\
\hline 2006 & $1,036,423$ & $12,849,432$ & 257,688 & $14,143,543$ \\
\hline 2007 & 981,302 & $10,553,668$ & & $11,534,970$ \\
\hline
\end{tabular}

Source: Annual Report, Ministry of Agriculture and Livestock

162. The construction of port infrastructures is a prerequisite for increasing fish production in the country. This explains our pleasure at the opening of two fishing ports at Nyanza-Lake and Kajaga, which should lead to some streamlining of this activity on Lake Tanganyika. The use of conservation and processing techniques would appear to be a priority action to make the fisheries resource a more visible development factor and to increase its share of contribution to GDP. In addition, the expansion of fish farming remains necessary in order to consolidate food security, in particular in rural areas.

\subsection{Environmental protection and improvement}

163. Safeguarding the environment will entail meeting three objectives, namely: (i) building the institutional and technical capacities of environmental agencies; (ii) promoting the national policy on natural resource management; and (iii) promoting the use of the natural resources and environmental rehabilitation 


\section{Building the institutional and technical capacities of environmental agencies}

164. Despite the efforts made for several years, environmental degradation has continued following repeated bad practices. These include arson, the repeated land clearings, the farming of marginal land, abusive deforestation, the anarchistic and illicit exploitation of mining products and quarries, and anarchistic exploitation of the land. Every year, the forest cover of Burundi decreases by 0.13 percent. In addition, the high population growth contributes to the degradation of natural resources and ecological conditions. The actions initiated in favor of the environment have been aimed at adapting the legal framework, mobilizing and heightening awareness about natural resource management, and promoting the sustainable use of natural resources and environmental restoration.

165. Harmonization of the legal framework was reflected in the adoption of an environmental code and the preparation of the necessary implementing provisions. Strengthening of the law as regards the environment is driven by a concern for sustainability, which presupposes a rational, balanced, and equitable management of resources, and for participation, which implies taking into consideration the opinions, needs, and interests of all the stakeholders concerned. The preparation of a draft decree implementing this code is in conformity with the procedure for socio-environmental impact studies and with the reports that are supposed to support revision of the land, forestry, mining, and petroleum codes, not to mention the report evaluating the legal framework governing public water resources.

166. Numerous studies have been conducted to assess environmental impacts. In addition, there have been some 60 environmental conformity certifications issued for the exploitation of mines and quarries. Other environmental protection and conservation studies have been undertaken with support from the Global Environment Fund, namely sectoral studies and studies of the national action plan for adaptation to climate change. There have also been inventories of the greenhouse gases in certain sectors (waste, land use/allocation, forestry, industrial practices, agriculture, and energy) in order better to prepare the second national message on climate change. An evaluation together with an action plan was prepared to build environmental management capacities. In addition, a national profile on the rational management of chemicals has been drawn up. Lastly, a baseline study on water quality control in Burundi has been carried out in the context of the Nile Basin Initiative.

167. In addition to the specific studies, a range of complementary actions was initiated throughout 2007. These actions made it possible to prepare tools and procedural handbooks for the management of greenhouse gas inventories (GGIs) on the one hand, and to implement an environmental information network in Burundi on the other.

168. For the Government, mobilization of the population is a precondition for the success of its environmental protection policy. The direct participation of several environmental protection associations took the form of public awareness, education, and information campaigns on sound ecological practices. In support of these positive associative dynamics, the regulations governing wood cutting were updated in order to discourage premature wood harvesting while facilitating the maintenance, and even the expansion, of individual and collective timber tracts. 
169. The results were insufficient as regards preventing and fighting wildfires. Admittedly, the five-year action plan 2006-2010 for the environment sector contemplates the control of wildfires by 2010. But given the poor results 2007 (127.5 km of fire breaks added and controlled burns of 662 hectares), additional efforts must still be made in order properly to control wildfires by end-2010.

170. In contrast, progress was made in the area of information and the training of stakeholders on the rational management of natural resources. Indeed, environmental education modules have just been developed for the elementary and secondary schools. Training sessions were organized on: (i) greenhouse gas inventory techniques and management; (ii) good practices and the management of uncertainties; (iii) quality assurance and control; (iv) management of the wetlands at Naiyvasha in Kenya; (v) the biological monitoring of water quality at Mwanza in Tanzania; (VI) environmental education in Addis Ababa and in Ethiopia; and (vii) training on the laws governing the protected areas. Also worthy of note are the training and retraining sessions on environmental safeguarding and soil protection. These sessions were organized for all commune-level and provincial leaders working in this sector of activity. An environmental police force and local monitoring committees were established to provide for the protection of the natural forests, parks, and public and private forest tracts. In 2007, training was provided to 11 environmental police officers out of a total staff of 456 . The ban on hunting wild animals constitutes an additional measure to protect natural resources.

171. The achievements in the area of safeguarding the environment in urban or periurban areas are encouraging, although further efforts remain to be made. In these areas, in particular in Bujumbura Mairie and in other secondary cities, these achievements include the improvement of ravines, the rehabilitation, maintenance, and expansion of public gardens, and drainage systems for waste water.

\section{Promotion of the national policy on natural resource management}

172. There is a real threat to natural resources and the environment in Burundi. The high population density, irregular topography, and poverty accelerate their degradation. The consequence is the drop in productivity owing to erosion and the overexploitation of land.

173. Formulation of a national territorial and land management policy is a fundamental stage in the planned and rational usage of land. Such a policy, in turn, must be guided by a national sustainable land usage strategy, which is already in place in Burundi. Based on this strategy, efforts to development provincial territorial development plans have been initiated, but at a pace that is quite slow still. Indeed, only two such plans have been completed in all 17 provinces, these for Kirundo and Bubanza Provinces. In view of the objectives of the five-year action plan 2006 -2010, the completion rate needs to be improved considerably. Noteworthy among the specific actions initiated are: (i) the development and introduction of an anti-erosion mechanism; (ii) development of a project for the protection and rehabilitation of the Ruvubu National Park, together with an impact study; and (iii) the rehabilitation of the Cankuzo-Muyinga road in that park. 


\section{Promotion of the sustainable use of natural resources and environmental rehabilitation}

174. The improvement of catchment basins facilitates soil preservation and the maintenance of soil productivity. Efforts are being made to this end, although the completion rate remains unsatisfactory. Indeed, the 9,703 hectares of catchment basins improved in 2007 fall short of compensating for the losses of land observed. The improvement and rehabilitation of marshes will contribute to the control of water and hence to increased agricultural production. In this area again, however, the completion rate is low. Indeed, the improvement of 2,787 hectares of marsh and the rehabilitation of 230 hectares of marsh are clearly shy of the projections for 2007 (improvement of 8,000 hectares and rehabilitation of 1,600 hectares) under the five-year action plan 2006-2010 for the environmental sector.

175. Reforestation and the inventory of forest tracts did not yield the results anticipated for 2007. Reforestation actions will ultimately lead to the reconstitution of destroyed plant cover and to the development of the forested patrimony. However, the results are short of the mark in that the projections of 4,000 hectares of trees to be planted annually exceed the actual performance, amounting to approximately 3,423 hectares in 2007 . In addition, the inventorying of forest tracts is proceeding at a very slow pace, and has been completed only for the tracts in Gakara and Buhayira, that is, 262 hectares. The remaining timber tracts in Burundi have yet to be inventoried. This constitutes a large gap as regards precise knowledge of the country's forest patrimony, thereby making its effective and sustainable management difficult.

176. The achievements made in connection with promoting the sustainable use of natural resources involve primarily the following aspects: (i) the production and distribution of 4,450 improved hearths; (ii) the establishment of two biogas projects in two secondary schools; (iii) rehabilitation of the INECN laboratory; (iv) maintenance of $137.5 \mathrm{~km}$ of firebreaks and $16.4 \mathrm{~km}$ of forest roads (this maintenance relates only to the forest stands of Gakara and Buhayira); and (v) creation of an effective system for monitoring the protected areas to reduce the rate of biodiversity disappearance in Africa.

\subsection{Development of trade and industry}

177. Overall, there was little growth in industrial and commercial activities between 2006 and 2007. Indeed, the relative change in industrial production during this period was only 0.3 percent, while the growth of the commercial sector registered just 0.4 percent. To remedy this situation, the implementation of reforms in trade and industry was accelerated, with actions aimed at improving the business climate and developing private initiative.

178. External support brought in significant resources targeting the relaunching of commercial and industrial development. On the trade side, the regional project to protect commercial activities against political risks allocated US\$7.5 million to Burundi over a 5 -year period. In the area of industrial promotion, the Integrated Framework for LDCs granted US\$1 million to support the private sector. This support was directed toward the production of essential oils (RUGOFARM), the expansion of flower cultivation (by the 
ATAB project), the drying of fruits and vegetables (COTRIEX project), quality management by $\mathrm{BBN}$, and the technological upgrading of the pipe factory.

179. Activities to promote domestic trade continued in 2007. Noteworthy accomplishments include the construction of modern marketplaces and the rehabilitation of business centers of trade under the PTPCE project. These achievements unquestionably supported the expansion of commercial activity. Upon the completion of these works, merchants' committees were set up to contribute to the management of these community infrastructures.

\subsection{Rational exploitation of mines and quarries}

180. The mines and quarries sector represents a very important opportunity for Burundi to increase and diversify export receipts. During 2007, the revenue from mining royalties paid into the account of the Public Treasury increased by 11 percent over the level for the preceding fiscal year. This revenue increase is explained by the approval of 61 local contact points, the granting of three hydrocarbon prospecting permits, the issuance of 599 mining licenses, and the approval of 1,829 authorizations to transport construction materials. This exclusively artisanal production activity supports over 200,000 people, that is, about 40,000 households throughout the country. To date, the effort to supervise construction material providers covers 13 provinces of the country, or 76.4 percent of the national territory.

181. The increased capacities resulting from the outfitting of the Control and Chemical Analysis Laboratory (LACED) made it possible to improve quality of the analyses. In the long term, mining research work will need to be intensified in order ultimately to permit the rational exploitation of mineral deposits whose potential will have been proven.

\subsection{Promotion of tourism and crafts}

182. There was some progress as regards promotion of the craft industry, but it remained insufficient in light of the objectives sought. A few artisanal units such as boilermaking shops, soap factories, bakeries, electric hullers, and motor-driven pumps could be established. In the tourism area, programs to relaunch activities could be carried out, such as those relating to the rehabilitation of the information and sales office. Other efforts involved repairing the pyramid at the source of the Nile and developing a database on tourist sites. The identification of new attractions and tourist products continued with a view to diversification and tapping the national potential and efforts to seek better links with the regional tourism circuits are in progress.

\subsection{Increased job and income-earning opportunities for the poor}

183. This orientation is at the crux of the poverty reduction programs. There are five [sic] preferred approaches to increasing job opportunities, namely: (i) improved access to credit; (ii) the promotion of highly labor-intensive public works; (iii) the promotion of income-generating activities and professional reinsertion; and (iv) the promotion of culture, sports, and leisure. 
184. In recent years there has been a proliferation of the microfinance institutions, the vast majority of which could not sustain their activities. Cascading bankruptcies occurred largely because of management omissions. In this regard, two major danger areas are often cited: lack of probity on the part of the promoters of microfinance, and the low repayment capacity of customers, itself directly related to high interest rates.

185. Restoring the credibility of the microfinance sector is crucial to improving the supply of credit in rural areas. Cognizant of its central role for growth and poverty reduction, the Central Bank of Burundi (BRB) is now closely supervising the financial activities of the microfinance institutions. It has also encouraged the creation of a Network of Microfinance Institutions (RIM) in order definitively to restore order to this sector. Overall, 26 microfinance institutions were licensed by the BRB at end-2007. Their financing is based primarily on contributions from projects and from NGOs involved in the sector.

186. The efforts to realign the sector have made it possible to resume offering microfinance services, despite the day-to-day difficulties. The information set forth in Table 9 makes it possible to assess the return to form of microfinance activities in Burundi. This being so, most microfinance institutions are functioning at well below cruising speed. They must further improve their analytical capacities and management of repayment default risk, which is very high in rural areas.

Table 9: Principal characteristics of microfinance in Burundi, 2007

\begin{tabular}{|l|l|}
\hline Population served & 311,094 customers or members \\
\hline Amount of loans granted & FBu $8,704,138,000$ (or US $\$ 8,704,138)$ \\
\hline Penetration rate & 10 percent \\
\hline Number of beneficiaries & 63,051 customers \\
\hline Average loan & FBu 138,050 (or US $\$ 138)$ \\
\hline Saving gathered & FBu $3,109,743,000$ (or US $\$ 3,109,743)$ \\
\hline Loans outstanding & FBu $13,897,427,000$ (or US $\$ 13,897,427)$ \\
\hline
\end{tabular}

Source: Bulletin d'analyse et d'information sur la micro-finance ZAMUKA, No. 10, March 2008.

187. Alongside the development of microcredit, the effectiveness of the traditional banking system is a key factor in stimulating growth. The Central Bank has taken actions in favor of consolidation and strengthening so that the financial sector can play such a role. The measures are aimed primarily at: (i) increasing bank capital, for which the minimum is now set at FBu 5 million; and (ii) facilitating the recovery of banks in difficulty. The BRB also plans to review bank licensing procedures, update the banking law, and launch a comprehensive study to evaluate the financial sector.

\section{Promotion of highly labor-intensive public works}

188. In addition to the paving work on the streets of Bujumbura Mairie, a number of highly labor-intensive activities were carried out thanks to the WFP. Through its "Food for Work" (FFW) program, it provided a food assistance to vulnerable persons in exchange of their participation in the construction of schools and health centers. This type of exchange was also used in the areas of road maintenance and rehabilitation and for 
environmental safeguarding (tracing of the contour lines and reforestation in connection with improving catchment basins and protecting cleared hills). Under the FFW program, the 45,622 households participating in the activities (that is, 228,112 beneficiaries) received 16,649 metric tons of food. The highly labor-intensive approach was also practiced by the UNDP through its community recovery programs which support the rehabilitation of socioeconomic infrastructures.

\section{Promotion of income-generating and professional insertion activities}

189. The opportunities for day labor, the primary income source for rural households, remained extremely limited for 2007. According to a study conducted out in April 2007 by the Center for Study and Research and Development in Agro-Economy (CERDA), the level of satisfaction of the demand for day labor was then 10 to 20 percent. This crisis situation on the labor market is worsened by the level of wages, which, despite the visible efforts of the government, remains insufficient in view of the constantly rising price of foodstuffs on the markets.

190. Increasing the incomes of rural families depends on the craft industry and on microprojects creating nonagricultural jobs. To develop these activities, the government is encouraging actions in the area of training, supervision, and the mobilization of suitable resources. Support takes the form of the organization and the creation of groups and associations of persons engaged in crafts, and the granting of small loans for the rehabilitation of production units destroyed during the crisis.

191. Other income-generating activities have also been sponsored by various associations led by the CDFs and other stakeholders like the UNDP. These activities include the milling by the electric hullers, joinery, sewing, and the manufacture and baking of bricks and tiles using tunnel kilns. Various initiatives carried out by national and international NGOs, making use of financing from development partners, also made it possible for many vulnerable youths (such as street children) to receive vocational training. These young people also received assistance with the creation of a professional association or an individual income-generating project.

192. The Vocational Training and Retraining Center (CFPP) is one of the preferred tools for professional insertion. Its primary mission is to build the capacities of the skilled workers for private enterprises and parastatals and those of more targeted organizations such as local production organizations of production. This center benefited from financing from SOS International in order to restructure programs, train the trainers, and renew instructional materials. The latter approach is essential for pursuing the intermediate objective of adapting the skill areas of the Center to the modern needs of beneficiaries. 


\section{Promotion of youth, sports, and culture}

193. Given the relative weight of youth in Burundi's population, ${ }^{1}$ specific actions were planned in 2007 to facilitate the effective integration of young people into productive activities. The actions contemplated were focused primarily on apprenticeship in trades, training for entrepreneurship, education in peace and national reconciliation, the creation of a fund for the economic insertion of youths, the establishment of regional youth centers, and an awareness campaign on the HIV/AIDS pandemic. There have been minor achievements in the area of youth outreach, the promotion of sports, and enhancing the value of national culture.

\section{Youth}

194. For 2007, the achievements fell short of the actions planned despite the demonstration of will on the part of the government and donors. An initial notable achievement was the construction of the offices for the regional youth centers. The personnel of these centers were redeployed, equipment was furnished, and vehicles purchased to facilitate the work of the regional and national coordinators. A second notable achievement involved BINUB support for carrying out the program to strengthen the participation of young people in social cohesion efforts within their respective communities.

\section{Sports}

195. Sports activities take place using several infrastructures of extremely poor quality. ${ }^{2}$ These are primarily the stadiums and fields developed and/or built by the public authorities in Bujumbura Mairie, Gitega, Ngozi, Bururi, and Makamba. Private initiative also contributes to the promotion of sport through the various sports federations. In addition, the UNDP contributed, through the PRRSLP, to construction/rehabilitation of soccer pitches and shared basketball/volleyball facilities in some provinces (Cankuzo, Karuzi, Makamba, Rutana, and Ruyigi).

196. In addition to the restoration of sports infrastructures, the promotion of sport was carried out through the development of the national sports policy, on the basis of which it was possible to restart a number of important activities. Thus, Burundi could once again take part in the organization of certain international competitions. Concerning sports institutions, efforts were made to monitor the operation of the national federations, organize technical and administrative training sessions (administrative and technical supervisors, trainers), and seek financing for the carrying out sports programs. In addition, public awareness campaigns on the fight against AIDS were conducted in conjunction with sports, leisure, and entertainment activities.

\footnotetext{
${ }^{1}$ According to ISTEEBU estimates, youths account for 50 percent of the overall population and 55 percent of the working population.

${ }^{2}$ Forthcoming improvement work will enable Burundi very soon to have quality infrastructures that meet international standards.
} 


\section{Culture}

197. Major cultural activities were organized in 2007, as follows:

(i) Support for youth for the creation of theater, music, dance, reading, and cinema clubs;

(ii) Organized activities for youths on vacation through leisure and entertainment activities;

(iii) Organization of national entertainment and leisure competitions;

(iv) Support for participations in international competitions and festivals;

(v) Identification film projection rooms, video libraries, and dance halls in order to ensure their monitoring in the interest of better protecting morals;

(vi) The reconstitution, training, and outfitting National Ballet's dance group;

(vii) Rehabilitation of the Palace of Arts and Culture;

(viii) Preparation of the festival of youth which is organized every two years around dances, traditional games, and physical and sports activities.

198. These encouraging efforts must be continued so that culture plays its role of cementing social cohesion in the country. In particular, major efforts should be made to ensure that the promotion of the cultural activities benefits the greatest possible number of the Burundians. This initially entails expanding the capacities to handle visitors to leisure and entertainment infrastructures (entertainment halls, green spaces, etc.).

\subsection{Development of the private sector}

199. The program to settle payments arrears was continued in order to maintain the dynamics of private sector recovery. Established by mutual agreement between the Government and donors, this program made it possible to disburse FBu 11.9 billion and FBu 21.5 billion in 2006 and 2007, respectively, for the payment of arrears owed to the private sector. The amounts owed to enterprise were settled mostly through the issuance of Treasury bills and bonds. At end-2007, the state no longer had any recorded arrears vis-à-vis national economic agents.

200. The organization of private sector activities benefited from government support, in particular through the granting of subsidies to the Burundi Normalization Office (BBN). To increase the production of handicrafts, the government also provided substantial resources to the artisan training centers of Kamenge, Kayanza, and Gitega. Donors also spared no efforts to support the organization of the private sector. Through its Arcane project, the European Union granted substantial support to this sector by: (i) helping it to set up its umbrella organization; (ii) conducting a study on reshaping the CCIB and preparing the practical guide for economic agents; (iii) offering it an Internet site; and (iv) taking part in the argument in defense of its interests.

201. To consolidate the process of reorganizing and relaunching the private sector, three series of targeted actions gained the attention of Burundi's authorities. First, progress was made with reforming the legal and regulatory framework thanks to the dissemination of the law on bankruptcy and competition, reactivation of the framework for private-public consultation, revision of the investment code, and updating of the code on private and public companies. The latter is necessary for their rapid adaptation to the new business framework resulting from Burundi's accession to the East African 
Community (EAC). Second, the Burundian business climate is on the path toward unquestionable improvement. The efforts made to this end relate to the preparation of an action plan to improve the investment climate, preparation of an industrial and commercial development strategy, and the updating of the commercial and mining codes. Third, the policy on providing greater incentives to the growth of private sector investment was continued. However, it was not possible to complete the extension of the banking and insurance network throughout the entire territory as envisaged, although gains are already perceptible in the major cities.

\subsection{Development of infrastructures supporting production}

202. The progress made in the area of basic infrastructures may be seen in three important respects, namely: analysis of the improvements made in transport infrastructures, the improvements in telecommunications infrastructures, and the increased energy supply capacities. The aim being sought is primarily to increase and enhance the competitiveness of Burundian enterprises.

\section{Improvement of transport infrastructure}

\section{Domestic transport}

203. The efforts to pave the regional and international roads are being compromised by the limited financial resources allocated to maintaining the existing network. This situation is likely to handicap the country's economic and social development initiatives inasmuch as the highway network is relatively dense. In the absence of continuous maintenance, it is difficult to guarantee traffic circulation and control over vehicle operation costs. The deterioration of the highway network, which reaches almost the entire territory, could ultimately mean increased rehabilitation costs and significant budgetary impacts. To neutralize these effects, the Roads Office has already performed the routine periodic maintenance work on the national highway network in general, and in the city of Bujumbura in particular. The rehabilitation works on the BujumburaGatumba highway and the protection of the Rusizi embankments have been completed, while those for the Rugombo-Kayanza highway are in progress.

204. The poor physical condition of the road infrastructures compounds the insufficiencies noted as regards accessibility to transportation. The results of the CWIQ2006 survey also confirm this problem, which arises with even greater acuity in rural areas for which the average time of travel before reaching the nearest functional road is about 46 minutes as compared to only 6 minutes for urban areas. A similar finding also applies as regards public transport. Indeed, in urban areas, publicly accessible means of transport are less than 15 minutes from home, compared with 83 minutes in rural areas.

205. There are many shortcomings relating to the organization of domestic transport for which satisfactory solutions could not be found. Consequently, transportation within the country is still completely outside the grasp and control of the administration. This is especially so in the area of ROAD SAFETY where the failings continue to grow. The principal constraints identified are: (i) the absence of fixed and improved bus stops, bus stations, improved parking facilities, and road signage (horizontal and vertical); (ii) the 
lack of rigor in technical inspections and the granting of driver's licenses; (iii) obvious problems with evaluating and controlling transport capacity for goods and merchandise (lack of reliable data on flows and regulatory omissions); and (iv) the inadequate training of inspection personnel.

206. There have been some notable organizational improvements in passenger transport to the interior of the country. This positive development has occurred despite the fact that the tariffs charged are still not very remunerative either for OTRACO or for the private operators. The problems are more glaring in the case of administrative transport in particular (the automobile fleet is ancient and far from uniform). To address these challenges, in 2007 the government prepared a framework law on road transport in Burundi and plans establish the broad outlines of a new administrative transport policy requiring overall financing of $\mathrm{FBu} 30$ million. Furthermore, to enhance road safety, a measure was taken to halt imports of left-hand drive public transport vehicles with effect from January 2, 2008. To speed up the essential reforms in this sector, the government has commissioned a feasibility study on an intercity bus station in Bujumbura Mairie at a cost of $\mathrm{FBu} 20$ million and urgent study on urban transport in Bujumbura Mairie against Japanese financing of $\mathrm{FBu} 3.3$ billion.

\section{International trade}

207. Burundi's policy on ending its isolation entails a choice to diversify access routes. This policy now places special emphasis on the rail connection to the subregional network. $^{3}$ The programs carried out in 2007, and those for which preparations are far along, are as follows:

- Conduct of the feasibility study on the ISAKA-NYAKARUHUKA-GITEGAMUSONGATI rail link;

- Construction of the KIRUNDI-GASENYI road on the Rwanda border;

- Conduct of the preliminary study piloted by COMESA on stabilization of the water level of Lake Tanganyika;

- Rehabilitation of the beacon lamps and lake signal buoys;

- Launch of a public tender offer for the dredging of the main basin of Bujumbura port.

208. On the institutional and regulatory level, encouraging milestones have been met. First, Burundi ratified the Agreement establishing the Central Corridor Transport and Transit Facilitation Agency. In addition, it also drafted the navigation code governing lake transport. However, it is important to note the persistence of thorny problems which enormously handicap the development of international transport in the country. These involve in particular:

- The outdated road infrastructures, air fleet, and port infrastructures and equipment;

- Tariff and nontariff barriers;

\footnotetext{
${ }^{3}$ Burundi's trade with the outside world depends in large measure on countries with a seacoast. Consequently, the major routes for ending Burundi's isolation are the southern corridor (via Lake Tanganyika), the north corridor (road), and the central corridor (lake and rail routes).
} 
- Limited axle loads;

- Alluvial deposits further complicating the negative effects of the lower water level in the Lake Tanganyika ports;

- The lack of legislation adapted to lake transport;

- The lack of a rail link to the subregion; and

- Personnel shortages in the international transport area.

209. In searching for a solution to the problems posed above, the government plans to take specific targeted actions. These basically involve: (i) negotiating the creation of warehouses that meet standards in transshipment ports (Dar Es Salaam, Kigoma, and Mpulungu); (ii) procuring modern equipment to ensure quality transportation over the various corridors; and (iii) participating in the definition of a common strategy for the development of infrastructures in the central and southern corridors (ports, railroads, roads, etc).

\section{Improvement of communications infrastructure and promotion of new information technologies}

210. The promotion of operational and modern communications should enable the government to further peace and economic recovery. The actions to be taken in this context are aimed at: (i) improving communications and information management to enhance the awareness of the public; (ii) organize communicators to enable them to provide professional (effective and high quality) communications consistent with the ethics code deontological governing the profession of journalist; (iii) coordinate the activities of all stakeholders in communication so as to harmonize the messages to be conveyed to the people; (iv) modernize and professionalize media enterprises; and (v) implement the national strategy on the development of NICTs.

211. Among the major achievements in the information and communications area are: (i) a Digital Development Support Center (ADEN) created in Gitega; (ii) digital upgrading of the radio and TV studios of the RTNB, and the training of the technicians in digital techniques; and (iii) the Internet establishment work undertaken in Kiremba in Bururi Province. These efforts are part of the policy of gradually spreading the Internet throughout the country. More specifically, journalists were able to benefit from a number of training sessions (seminars or workshops) organized in Burundi or abroad on communications and the NICTs. Among most important of these are: (i) a training seminar on defense of the rights of children, with UNICEF support; (ii) a training seminar on the role of the journalist in the process of establishing the Truth and Reconciliation Commission; (iii) a workshop on the legal and regulatory framework of the media in Burundi; (iv) training on investigative journalism; (v) CIEP staff training on digital editing; (vi) five training sessions for journalists on ethics, compliance with the law, and media accountability; and (vii) the participation of public and private radio journalists in international seminars on communications and the NICTs, held in China, Belgium, France, Italy, and the Republic of South Africa.

212. In the telecommunications sector, the spread of mobile telephony made impressive progress. In this regard, the AFRICEL, ECONET, ONAMOB, and Ü-COM firms managed to extend their networks to most of Burundi's major cities. The 
multiplicity of telephony providers throughout the country enormously facilitates communications. Additional efforts must be made in a sensitive area, namely the cost of such communication. The current cost level unquestionably constitutes a brake on broader telephone usage in Burundi, especially in rural areas. ${ }^{4}$

\section{Increased energy supply capacities}

213. There was significant growth in the production of electricity in Burundi in 2007, facilitated by the frequent rains recorded in the country recorded that year. Electricity production was thus much better in 2007 than in 2006 when there was a pronounced water shortage and multiple diversions. The Ministry of Water, Energy, and Mining, responsible for electrification of the country through REGIDESO and DGHER, increased electricity production by 24.2 percent. This noteworthy increase is explained not only by favorable rains, but also and especially by the 2007 launch of maintenance and rehabilitation works on the hydroelectric plants and their associated networks. ${ }^{5}$

214. For the short term, the government opted to invest on a priority basis in the rehabilitation of existing power plants and in the extension of the service grids. Accordingly, the hydroelectric plants at Ruvyironza (Gitega) and Gikonge (Muramvya) could be rehabilitated. These works increased their installed capacities from 1.275 MW to $1.5 \mathrm{MW}$ and from $0.85 \mathrm{MW}$ to $1 \mathrm{MW}$, respectively. At the same time, the hydroelectric plants in the north (Rwegura, Kayenzi, and Maramvya) were interconnected in order to guarantee the security of electricity supply of electricity and stabilize the grid.

215. The achievements in the area of rural electrification continued and were extended. Overall, the DGHER electrified 19 additional rural centers installing new lines, distributed as follows: three in Kabarore commune, two in Bugendana commune, three in Rumonge commune, one in Makamba commune, one in Bururi commune, two in Burambi commune, one in Kiganda, one in Gitega commune, two in Butaganzwa commune, one in Muhanga commune, and two in Mugina commune. It is also important to stress that nine additional health centers were electrified. In support of the country's electrification program, the Directorate-General of Water and Energy is currently completing the electrification of 35 health centers and 17 commune-level secondary schools, all in rural areas, using photovoltaic solar systems. Expansion and electrification efforts in the peripheral areas of the urban centers are ongoing as well, with a view to increasing electricity access there.

216. Accessibility to electrical energy on the part of Burundian citizens appreciably improved in 2007. This positive tendency goes hand in hand with an increase in electricity production, which went from 152,056.5 MWh in 2006 to 142.824 MWh in 2007. Moreover, there was some improvement in the technical and commercial losses of

\footnotetext{
${ }^{4}$ In order to increase access to telephony in Burundi significantly, a very important project is currently in the gestation phase. It involves in particular the proposal to link Burundi to the international communications network by the fiber optic link that bypass the continent on the east and west.

${ }^{5}$ These efforts are ongoing.
} 
REGIDESO recorded a certain improvement. Overall, these $\operatorname{losses}^{6}$ measure the difference between the quantity of energy produced and the amount actually invoiced. They declined from 26 percent in 2006 to 24.4 percent in 2007 , which is quite a performance by itself. Performance indicators for the reduction of these losses had in fact been set with the World Bank, as follows: 24 percent in 2009, 23 percent in 2010, 21 percent in 2011, 19 percent in 2012, and 18 percent in 2013.

217. Regarding the demand for electricity, the number of electricity sector subscribers increased by 6.7 percent, from 35,200 in 2006 to 41,074 in 2007. In terms of the number of subscribers per category, low tension (LT) customers increased from 35,200 in 2006 to 37,660 in 2007, while there was no change overall in the number of medium tension (MT) customers. The main cause of this stagnation appears to be the sociopolitical crisis that has affected Burundi for the past decade. The number of medium tension customers thus dropped from 129 in 2006 to 115 in 2007 . The trend for electricity subscribers by consumption center is shown in Table 10.

Table 10: Change in electricity subscribers

\begin{tabular}{|l|c|c|c|c|c|c|c|}
\hline Center & $\mathbf{2 0 0 2}$ & $\mathbf{2 0 0 3}$ & $\mathbf{2 0 0 4}$ & $\mathbf{2 0 0 5}$ & $\mathbf{2 0 0 6}$ & $\mathbf{2 0 0 7}$ & $\begin{array}{c}\text { Rate of growth (in } \\
\text { percent) }\end{array}$ \\
\hline Bujumbura & 19,466 & 20,754 & 21,025 & 20,256 & 21,510 & 22,974 & 4.5 \\
South & 2,061 & 2,208 & 2,366 & 2,494 & 2,754 & 3,827 & 10.4 \\
North & 3,351 & 3,707 & 3,932 & 4,039 & 4,409 & 3,225 & 9.1 \\
West & 2,183 & 2,340 & 2,492 & 2,492 & 2,905 & 2,923 & 16.5 \\
East & 2,168 & 2,906 & 3,257 & 3,257 & 3,558 & 4,711 & 9.2 \\
\hline Major domestic consumer & & & & 64 & 64 & & - \\
\hline Total & $\mathbf{2 9 , 6 7 4}$ & $\mathbf{3 1 , 9 1 5}$ & $\mathbf{3 2 , 8 8 9}$ & $\mathbf{3 2 , 9 8 6}$ & $\mathbf{3 5 , 2 0 0}$ & $\mathbf{4 1 , 0 7 4}$ & $\mathbf{6 . 7}$ \\
\hline
\end{tabular}

Source: Ministry of Energy and Mines.

218. The promotion of other energy resources was extremely uneven. First, the use of biomass and renewable energies is difficult assess owing to the lack of reliable data. ${ }^{7}$ Second, the production of peat lost much ground, declining from 9,762 metric tons in 2006 to 7,450 metric tons in 2007. This drop of approximately 30 percent has two origins, namely: outdated production equipment and lack of spare parts. This type of fuel is mainly consumed by military camps and by detention facilities. ${ }^{8}$ Third, the use of improved hearths, which makes it possible to limit environmental pollution through deforestation, began to be implemented. The real impact of these hearths on the environment will not be perceptible for about a decade, so long as they are properly used in tandem with a policy to intensify reforestation efforts.

\footnotetext{
${ }^{6}$ Technical losses are associated with the transport of energy (losses related to the outdated grid). Commercial losses are associated with defective meters and possible fraud by certain customers (direct connections, meter manipulation).

${ }^{7}$ The difficulties stem from the absence of up-to-date data on their potential (reserves), their production, and their quantitative consumption, which does not make planning and management in this area any easier.

${ }^{8}$ The introduction of a coalification unit to tap the enormous potential available to the country could reduce the pressure on its plant cover and forest resources.
} 
219. Burundi is convinced that the creation of regional economic units is an important development niche that it fully intends to make use of. Moreover, the government is persuaded that this is one of the proper paths for triggering and bolstering growth, thanks in particular to the broadening of market outlets and to facilities for the procurement of basic commodities. In this regard, Burundi's accession to the East African Community on June 18, 2007 represents a significant step in this direction. It is now participating in overall (political, economic, and social) integration efforts which will should lead to a customs union, a common market, and a monetary union, and to a political federation in the final stage. ${ }^{9}$

220. Burundi has thus already begun to participate in the various programs carried out within the framework of community cooperation. These programs cover broad areas such as:

(i) Foreign policy coordination;

(ii) Cooperation in the defense and security areas;

(iii) Legal and judicial cooperation;

(iv) Interparliamentary cooperation;

(v) Political federation;

(vi) Cooperation in the areas of the trade, finance, and investment;

(vii) Cooperation in the productive sectors;

(viii) Cooperation in the infrastructure and services sectors; ${ }^{10}$

(ix) Contribution to the Community budget;

(x) Facilitation of the movement of nationals from the Community.

221. Burundi has twelve months from the date of signature of the Treaty to apply Community legislation and make it enforceable. ${ }^{11}$ In particular, this involves conferring on the Community the legal capacity and the juridical personality required for it to carry out its missions. In other words, Burundi must give force of law within its territory to the legislation, Rules, and Directives of the Community. It is therefore important that the governmental authorities undertake the reforms necessary to conform to same and thereby have the same instruments as its Community partners.

222. It is important to note that Burundi has opted to join the EAC while remaining a member of regional bodies in which it has strategic and vital interests. These are the Economic Community of the Great Lakes Countries (CEPGL), the Economic Community of Central African States (ECCAS), the Common Market for Eastern and

\footnotetext{
${ }^{9}$ Moreover, Burundi's EAC membership will contribute to stabilizing the country at the political and security levels, to supporting the development of a regional migration policy, and laying the groundwork for sustainable development.

${ }^{10}$ This relates in particular to the Road Network Project and to the tripartite agreement on road transport, the master plan for the development of railroads, civil aviation, and air navigation, the postal projects, and the master plan for energy calling for interconnection of the power grids of the member states and for exploration of their oil resources.

${ }^{11}$ According to Article 2 of Burundi's Treaty of Accession to the EAC.
} 
Southern Africa (COMESA), the Nile Basin Initiative (NBI), and the New Partnership for Africa's Development (NEPAD).

223. The ECCAS functions in its political and diplomatic aspects in the areas of common defense and mutual legal assistance. However, its functioning needs to be strengthened in the economic area. In contrast, COMESA is at an advanced stage in terms of regional integration. The Free Trade Zone is already operational between Burundi and the Member States preparing for an imminent Customs Union. A COMESA delegation also visited Burundi in early November 2007 to promote the "Trade for Peace" project, which is aimed at intensifying trade flows in the Great Lakes area and at developing postconflict reconstruction and development strategies. For its part, the CEPGL is still in the revival stage after a long interruption of its activities following the civil wars afflicting the three Member States since 1994. The Executive Secretariat has been set up and should shortly be completed by the designation of the officials representing the Democratic Republic of Congo. As regards the NBI, programs have been initiated, in particular for water management and environmental protection, even though it still lacks an institutional framework for cooperation among the Member States. Furthermore, Burundi is part of the International Conference on the Great Lakes Region and hosts the latter's secretariat. ${ }^{12}$

224. To streamline its participation in regional integration bodies, Burundi took an active part in the conduct of two impact studies on its entry into the EAC. Financial support was provided by the World Bank and the GTZ. The conclusions of these studies should become available during 2008. Even now, Burundi should be taking cohesive political steps in order to benefit from this integration. Not only it will have to harmonize its policies with those of its partners, but it will also have to also introduce new measures within the various cooperation frameworks in order to create suitable institutional and regulatory frameworks.

\section{DEVELOPMENT OF HUMAN CAPITAL}

\subsection{Promotion of education}

\section{The partnership framework and principal accomplishments}

225. The axes for the future development of the education sector in Burundi are clearly set forth in the RESEN. ${ }^{13}$ Five objectives were identified in an educational policy letter that the government adopted in end-2006; the activities necessary for achieving them began to be implemented immediately. It should be noted that these objectives are: (i) achieving universal completion of the primary cycle in 2015; (ii) managing in a controlled manner the flow of students beyond public education; (iii) improving the

\footnotetext{
${ }^{12}$ The implementation of the Regional Security, Stability, and Development Pact covers many areas of intervention necessary to the consolidation of peace, both in Burundi and in the region.

13 The Status Report on the National Education System (RESEN), published in December 2006, is based on a detailed assessment of the status of the education sector, which began in 2005 .
} 
quality and relevance of primary education; (iv) ensuring a fair educational system; and (v) ensuring greater efficiency in the use of resources.

226. The government and its partners set up a coordination framework to orient the programs to achieving results. More specifically, the Ministry of National Education and Scientific Research developed a coordination framework with the technical and financial support of donors and UNICEF to establish the necessary synergies and a realistic sectoral plan consistent with the PRSP. To this partnership framework's credit, the following achievements are worthy of mention: (i) preparing the Sectoral Plan for the Development of Education and Training; (ii) preparing the action plan that details the activities to be implemented by 2010; (iii) launching a Medium-Term Expenditure Framework (MTEF) to ensure that the action plan is financially sustainable; and (iv) implementing a donor-supported Common Education Fund, already operational. This partnership framework is a major asset for accessing the different external financial supports.

227. As the principal party involved in education, Burundi has continued to finance current and investment expenditures to support this vital sector. The majority of these expenditures cover the wages of teachers and school operating expenses. These expenditures are closely linked to gradually implementing a series of measures and projects at the sectoral level to rebuild and renovate school infrastructures, to expand and train teaching staff, and to improve programs. An effort is also being made to give students and teachers appropriate materials and educational resources, as well as the teaching supervision that goes with them.

\section{Financing for the education sector}

228. Teacher training and retraining is continuing to improve the effectiveness and quality of the education system. Likewise, to make it easier for the country to be part of the sub-regional bodies, the government has just introduced English and Kiswahili into education programs, beginning with basic education.

229. Since 2006, the government has also obtained considerable resources from the HIPC Initiative. Used mainly to finance infrastructure, HIPC resources were used to build 500 new classrooms in primary schools and to renovate others. 
Table 11: External financing for the education sector in 2007 (millions of FBu).

\begin{tabular}{|c|c|c|c|c|c|c|c|c|c|c|}
\hline $\begin{array}{c}\text { Level of } \\
\text { education }\end{array}$ & WB & UNICEF & WFP & CTB & AFD & $\begin{array}{c}\text { French } \\
\text { Coop. }\end{array}$ & CNR & Others & Total & \% \\
\hline Preschool & 0 & 320 & 0 & 0 & 0 & 0 & 0 & 0 & 320 & 1 \\
\hline Primary & 8,053 & 12,653 & 6,896 & 6,514 & 0 & 69 & 1,618 & 0 & 35,803 & 72 \\
\hline $\begin{array}{c}\text { Secondary } \\
\text { general }\end{array}$ & 961 & 0 & 0 & 833 & 0 & 235 & 0 & 0 & 2,029 & 4 \\
\hline $\begin{array}{c}\text { Technical } \\
\text { secondary }\end{array}$ & 0 & 0 & 0 & 2,924 & 0 & 0 & 0 & 0 & 2,924 & 6 \\
\hline $\begin{array}{c}\text { Higher } \\
\text { Perser levels }\end{array}$ & 0 & 0 & 0 & 254 & 0 & 6 & 380 & 2,680 & 3,314 & 7 \\
\hline $\begin{array}{c}\text { Other } \\
\text { allocated to a } \\
\text { level }\end{array}$ & 165 & 0 & 0 & 0 & 3,120 & 0 & 0 & 0 & 4,745 & 10 \\
\hline Total & $\mathbf{1 0 , 6 3 8}$ & $\mathbf{1 2 , 9 9 3}$ & $\mathbf{6 , 8 9 6}$ & $\mathbf{1 0 , 5 2 5}$ & $\mathbf{3 , 1 2 0}$ & $\mathbf{8 9 7}$ & $\mathbf{1 , 9 9 8}$ & $\mathbf{2 , 6 8 0}$ & $\mathbf{4 9 , 7 4 7}$ & $\mathbf{1 0 0}$ \\
\hline
\end{tabular}

Source: Ministry of Finance.

230. Priority for using the external financing for the education sector was placed on primary education (72 percent). For the remaining external financing resources, the breakdown is as follows: staff training - 5 percent; everyday operations - 3 percent; investment and equipment - 7 percent, miscellaneous student aid - 18 percent, and other financing - 4 percent. The preschool level does not seem to be a priority for financing education, even if its importance in child development is acknowledged. This imbalance deserves to be corrected as soon as possible.

Results of the 2006 QUIBB survey

231. The most recent estimates indicate that the overall literacy rate in the country is low. Literacy rates, used to evaluate the people's aptitudes for reading and/or writing, either in Kirundi or foreign languages are shown in Table 12. 
Table 12: Breakdown of school registrations in 2006.

\begin{tabular}{|c|c|c|c|c|c|c|}
\hline & \multicolumn{2}{|c|}{ Literacy training } & \multicolumn{4}{|c|}{ School registrations - Current year } \\
\hline & Kirundi & Others & Kindergarten & Primary & Secondary & University \\
\hline Boys & 57.69 & 31.41 & 54.52 & 52.19 & 56.53 & 64.22 \\
\hline Girls & 50.18 & 25.36 & 45.48 & 47.81 & 43.47 & 35.78 \\
\hline Quintile 1 & 44.15 & 20.41 & 15.03 & 22.22 & 11.62 & 1.94 \\
\hline Quintile 2 & 48.71 & 22.30 & 8.56 & 22.37 & 13.59 & 1.80 \\
\hline Quintile 3 & 51.29 & 25.99 & 11.61 & 20.76 & 20.75 & 11.49 \\
\hline Quintile 4 & 54.94 & 28.40 & 19.09 & 20.08 & 21.14 & 11.34 \\
\hline Quintile 5 & 62.59 & 39.59 & 45.71 & 14.58 & 32.90 & 73.44 \\
\hline Urban & 75.43 & 58.91 & 27.86 & 6.26 & 21.55 & 67.91 \\
\hline Rural & 50.91 & 25.41 & 72.14 & 93.74 & 78.45 & 32.09 \\
\hline Bubanza & 50.44 & 24.03 & 0.00 & 3.85 & 2.96 & 0.00 \\
\hline Bujumbura Mairie & 76.29 & 60.29 & 19.65 & 4.53 & 18.00 & 67.56 \\
\hline Bujumbura Rural & 57.70 & 34.75 & 2.69 & 9.00 & 9.35 & 13.79 \\
\hline Bururi & 59.74 & 38.39 & 2.13 & 8.64 & 14.66 & 13.93 \\
\hline Cankuzo & 50.29 & 20.53 & 0.00 & 1.81 & 1.51 & 0.00 \\
\hline Cibitoke & 47.04 & 27.64 & 0.82 & 5.27 & 4.71 & 0.00 \\
\hline Gitega & 63.48 & 32.06 & 7.01 & 9.39 & 8.68 & 1.92 \\
\hline Karuzi & 63.85 & 33.57 & 16.28 & 7.86 & 6.86 & 0.00 \\
\hline Kayanza & 45.80 & 15.51 & 0.96 & 4.98 & 1.05 & 0.00 \\
\hline Kirundo & 39.51 & 13.52 & 14.64 & 7.98 & 4.20 & 0.00 \\
\hline Makamba & 54.22 & 29.25 & 0.00 & 5.79 & 5.42 & 0.00 \\
\hline Muramvya & 55.30 & 24.58 & 0.00 & 4.32 & 4.06 & 0.00 \\
\hline Muyinga & 42.18 & 18.45 & 19.69 & 5.71 & 4.65 & 0.00 \\
\hline Mwaro & 56.88 & 31.77 & 1.12 & 3.84 & 3.93 & 0.00 \\
\hline Ngozi & 41.90 & 20.69 & 15.01 & 7.29 & 4.54 & 2.79 \\
\hline Rutana & 43.39 & 21.86 & 0.00 & 4.95 & 3.54 & 0.00 \\
\hline Ruyigi & 46.76 & 21.88 & 0.00 & 4.79 & 1.88 & 0.00 \\
\hline Total & 52.32 & 27.32 & 100 & 100 & 100 & 100 \\
\hline
\end{tabular}

Source: Estimates based on the 2006 QUIBB.

232. According to the estimates in the first two columns, slightly more than one of every two Burundians is able to read and/or write Kirundi in 2006. As for foreign languages, the rates are significantly lower, as less than one of every three persons in the country stated that they are able to read and/or write. A review of these simple quality indicators shows the difficulties the educational system in Burundi is facing in carrying out one of its fundamental missions, even in 2006.

233. In addition to substantial gender disparities, the low literacy levels go hand-inhand with poverty and place of residence. First, men are undeniably more literate than women, regardless of language. Moreover, the ability to read and write is much greater for individuals living in a wealthy household (Quintile 5) than in a poor one (Quintile 1). Finally, the urban areas in general and Bujumbura Mairie in particular (79.3 and 60.3 in Kirundi and other languages respectively), have much better results. 
Table 13: Education performance indicators in $\mathbf{2 0 0 6}$

\begin{tabular}{|c|c|c|c|c|c|c|c|c|}
\hline & \multicolumn{4}{|c|}{ Net enrollment rate } & \multicolumn{4}{|c|}{ Gross enrollment rate } \\
\hline & Kindergarten & Primary & Secondary & University & Kindergarten & Primary & Secondary & University \\
\hline Boys & 1.68 & 73.24 & 12.71 & 1.46 & 2.58 & 120.26 & 20.53 & 2.08 \\
\hline Girls & 1.71 & 73.58 & 9.89 & 0.70 & 1.91 & 116.63 & 14.30 & 0.86 \\
\hline Quintile 1 & 0.69 & 62.45 & 4.47 & 0.22 & 1.58 & 101.09 & 7.32 & 0.22 \\
\hline Quintile 2 & 0.89 & 68.10 & 6.87 & 0.17 & 0.89 & 106.98 & 9.89 & 0.17 \\
\hline Quintile 3 & 0.68 & 71.80 & 10.95 & 0.72 & 1.53 & 114.34 & 16.65 & 0.84 \\
\hline Quintile 4 & 1.94 & 79.20 & 11.81 & 0.65 & 2.01 & 126.01 & 18.64 & 0.65 \\
\hline Quintile 5 & 4.72 & 80.82 & 21.43 & 1.99 & 5.91 & 132.95 & 32.63 & 2.95 \\
\hline Urban & 10.90 & 90.07 & 34.55 & 8.09 & 12.30 & 140.15 & 57.68 & 11.40 \\
\hline Rural & 1.19 & 70.01 & 8.75 & 0.38 & 1.72 & 112.27 & 13.12 & 0.46 \\
\hline Bubanza & 0.00 & 67.67 & 6.56 & 0.00 & 0.00 & 118.54 & 11.16 & 0.00 \\
\hline Bujumbura Mairie & 10.45 & 91.38 & 36.82 & 9.72 & 12.03 & 143.54 & 64.11 & 13.71 \\
\hline Bujumbura Rural & 0.84 & 82.64 & 11.61 & 2.76 & 0.84 & 145.39 & 17.21 & 2.76 \\
\hline Bururi & 0.67 & 83.38 & 18.40 & 1.57 & 0.70 & 140.38 & 31.13 & 2.68 \\
\hline Cankuzo & 0.00 & 78.08 & 10.62 & 0.00 & 0.00 & 127.50 & 13.17 & 0.00 \\
\hline Cibitoke & 0.25 & 60.74 & 10.37 & 0.00 & 0.25 & 89.96 & 14.53 & 0.00 \\
\hline Gitega & 1.55 & 76.47 & 9.30 & 0.31 & 2.13 & 118.99 & 13.83 & 0.31 \\
\hline Karuzi & 2.64 & 74.38 & 10.42 & 0.00 & 4.10 & 108.14 & 14.85 & 0.00 \\
\hline Kayanza & 0.37 & 61.65 & 2.14 & 0.00 & 0.37 & 95.30 & 3.03 & 0.00 \\
\hline Kirundo & 3.12 & 56.67 & 4.12 & 0.00 & 3.43 & 94.33 & 7.27 & 0.00 \\
\hline Makamba & 0.00 & 80.02 & 12.77 & 0.00 & 0.00 & 127.02 & 17.58 & 0.00 \\
\hline Muramvya & 0.00 & 80.03 & 10.23 & 0.00 & 0.00 & 137.37 & 14.38 & 0.00 \\
\hline Muyinga & 4.16 & 61.58 & 9.08 & 0.00 & 6.37 & 97.56 & 11.22 & 0.00 \\
\hline Mwaro & 0.30 & 86.05 & 10.46 & 0.00 & 0.73 & 139.32 & 17.67 & 0.00 \\
\hline Ngozi & 2.43 & 60.16 & 6.38 & 0.39 & 3.40 & 91.31 & 8.06 & 0.39 \\
\hline Rutana & 0.00 & 67.44 & 8.12 & 0.00 & 1.45 & 106.96 & 13.01 & 0.00 \\
\hline Ruyigi & 0.00 & 71.47 & 3.80 & 0.00 & 0.00 & 115.65 & 6.52 & 0.00 \\
\hline Total & 1.67 & 71.03 & 10.26 & 0.99 & 2.24 & 113.68 & 15.73 & 1.33 \\
\hline
\end{tabular}

Source: Estimates based on the 2006 QUIBB

234. There are also striking disparities in the breakdown of school registrations, regardless of the school level considered. First, the number of girls is always lower in kindergarten, primary school, secondary school, and even at the university, where the disparity is at its highest level. However, it should be noted that the breakdown is more even between girls and boys in primary education. Moreover, the poverty status of the household of origin emerges clearly as a decisive factor in encouraging children to register for school. This factor seems to be stronger for kindergarten, secondary school and higher education. The gaps between rich and poor are particularly dramatic for these levels of education. Primary school is more balance based on the breakdown of school registrations through the consumption quintiles in per-capita adult equivalents.

235. The net enrollment rates for primary and secondary schools are high, at 71 percent and 10.3 percent respectively in 2006. In clear terms, children enrolled in primary school with the required age (7-12 years old according to the Ministry of Education) accounted for just 71 percent of the total population of actual primary school-age children in 2006 . 
For secondary school, the low net enrollment rate points to the fact that students drop out of school, and this is related to the infrastructure at the secondary level for accommodating students. This low rate also indicates that lags in registrations for primary school are likely. A detailed analysis of the national net enrollment rates shows flagrant disparities according to poverty status, environment and the province where children reside. For example, the gap in net rates between poor children and rich children is roughly 18 percentage points for primary schools and 17 percentage points for secondary school. Rural areas perform much worse, while Bujumbura Mairie alone has a net rate that exceeds 91 percent.

236. Gross enrollment rates are reaching levels that indicate high levels of lags in registrations as well as students who repeat grades in primary school. The national average of primary and secondary enrollment rates stood at around 113.7 percent and 15.7 percent in 2006 respectively. Once again, these overall results show a numerical advantage for boys, children from wealthy households, and urban children. A similar numerical advantage is also observed for kindergarten and higher education.

237. A recent World Bank study shows that primary education performances in 2006 would have benefitted from the free tuition policy that the government decreed in September 2005. Three results are of particular interest and merit comment. First, the study showed the impact of free tuition on primary school enrollment in children from poor households. In fact, if primary school were not free, just over 41 percent of poor households stated that some of their children who registered for primary school in 2006 would have stayed home. For wealthy households, this proportion was just 13 percent. Next, the study showed that before the 2006 school year, about 32 percent of poor households stated that at least one of their children was unable to attend school due to a lack of money to pay tuition. Finally, the other noteworthy result is that around 38 percent of poor households with children who stayed at home in 2005 because of tuition were able to register some of these children in school in 2006. The cost of school materials, clothing (uniforms), and in particularly the opportunity cost, is still very high for poor families.

\section{Performance analysis}

238. The various methods that the government and donors use produced appreciable outcomes. These methods facilitated implementing new strategic policies for the education sector and accelerated the institutional reforms. The current situation is characterized by the recent and swift growth in the number of students in primary education and, to a lesser extent, in secondary education. This notable growth is obviously the result of several factors, including the renewed peace and the elimination of tuition in primary school, as they play a central role. Table 14 below shows this impressive trend in primary school enrollment rates. 
Table 14: Change in gross primary school enrollment rates by province

\begin{tabular}{|l|c|c|c|c|}
\hline PROVINCE & $\mathbf{2 0 0 3 - 2 0 0 4}$ & $\mathbf{2 0 0 4} \mathbf{- 2 0 0 5}$ & $\mathbf{2 0 0 5}-\mathbf{2 0 0 6}$ & $\mathbf{2 0 0 6}-\mathbf{2 0 0 7}$ \\
\hline BUBANZA & 70.5 & 71.2 & 86.6 & 95.2 \\
\hline BUJUMBURA-MAIRIE & 101.8 & 124.3 & 141.9 & 119.8 \\
\hline BUJUMBURA-RURAL & 92.3 & 86.9 & 95.6 & 116.6 \\
\hline BURURI & 112.5 & 108.3 & 122.2 & 140.9 \\
\hline CANKUZO & 75.8 & 74.9 & 97.5 & 79.8 \\
\hline CIBITOKE & 77.2 & 74.6 & 91.9 & 101.7 \\
\hline GITEGA & 93.8 & 88.9 & 106.6 & 112.0 \\
\hline KARUSI & 78.9 & 83.2 & 100.1 & 104.5 \\
\hline KAYANZA & 68.7 & 75.2 & 102.8 & 97.2 \\
\hline KIRUNDO & 70.3 & 63.9 & 88.8 & 86.7 \\
\hline MAKAMBA & 78.7 & 82.6 & 101.2 & 114.3 \\
\hline MURAMVYA & 96.2 & 96.3 & 115.4 & 125.3 \\
\hline MUYINGA & 57.8 & 56.4 & 74.7 & 85.7 \\
\hline MWARO & 111.1 & 106.8 & 122.0 & 128.7 \\
\hline NGOZI & 58.3 & 57.1 & 86.4 & 91.5 \\
\hline RUTANA & 85.3 & 90.9 & 117.8 & 96.3 \\
\hline RUYIGI & 63.5 & 80.1 & 105.8 & 101.4 \\
\hline Total & $\mathbf{8 1 . 0}$ & $\mathbf{8 1 . 6}$ & $\mathbf{1 0 1 . 3}$ & $\mathbf{1 0 5 . 2}$ \\
\hline Source Ministry & & & & \\
\hline
\end{tabular}

Source: Ministry of National Education.

239. The improvement in the gross enrollment rate is the result of measures taken in synergy by the government and partners. These measures include: (i) eliminating tuition for primary education; (ii) building school cafeterias and adding incentives to keep girls in primary schools; (iii) making efforts to build, renovate and outfit schools (separate lavatories for girls and boys and water points); (iv) providing manuals and other school materials; and (v) hiring teachers. For the school cafeterias, the WFP distributed 5,972 metric tons to 248,256 recipients in 2007.

240. Thus, it is obvious that current capacities are overwhelmed due to the influx of new children, most of whom are no longer of the required age for primary school. Once the number of students increased significantly, the student-teacher ratio rose from 67.2 in 2000 to 86.3 in 2006. Thus, Burundi is characterized by a very high student-teacher ratio. This mechanical increase may significantly jeopardize the general quality of the teaching provided in primary schools. Moreover, despite the gradual improvement in enrollment rates, considerable efforts must still be made to achieve universal primary education in the coming years.

241. In general, the effectiveness of the education system has remained low. Of 100 students registered in the first year of primary school, only 37 will go on to secondary school, and just eight and four children respectively will move on to the second cycle of secondary education and the last year of secondary school. For the university level, the academic infrastructure problem is a real barrier to promoting university education, even if private universities have alleviated this situation somewhat. The university enrollment rate is estimated at 2.6 percent, and this ranks Burundi as one of the countries in Africa with a very low university enrollment rate. 


\section{Outlook for the future}

242. The ambitious goal of educating all children from 7 to 12 years old in primary schools by 2015 will require considerable and sustained efforts in the coming years. It should be noted that at this time just four in ten children that start the first year complete their primary schooling. Despite the efforts ${ }^{14}$ made to increase performances, the requirements to be covered continue to be important nevertheless. The persistence of the double-sided organization is one of the signs of these requirements when it is not quite simply a major drawback for the quality of education. In this regard, two simple indicators provide an interesting idea of the general quality of primary education. These are: the percentage of repeaters (30.3 percent) and the percentage of dropouts (7.2 percent) in 2005-2006. It is important to also concentrate on software efforts to improve quality, notably by strengthening teaching skills through initial training and continuing education. The learning and teaching environment must be strengthened as well.

243. To achieve universal education by the beginning of the 2015-2016 school year, all children should be registered in the first year of school at the beginning of the 2010-2011 school year. Support measures for sufficiently producing teaching materials and expanding opportunities for accommodating students at the secondary level, in particular, and increasing the number of vocational schools, should be carefully studied and implemented. But universal education also requires raising the primary school completion rate to 100 percent by the beginning of the 2015-2016 school year, versus a current rate of 37 percent. Consequently, there should be around two million school-age students. Achieving such a goal requires a considerable increase in capacities. ${ }^{15}$ Estimates for 2007 show an increase of up to 95 percent.

244. In terms of targets for future education policies, it appears that the priority for the next few years is to increase national school coverage. This will require hiring teachers as a corollary, which will cause the recurring costs of the system to rise. Thus, it is imperative to reflect in detail about the future education policy with a view to sustainable financing in the medium term. The implementation of the Sectoral Plan for the Development of Education and Training must be accelerated for this to happen. Actions required to achieve universal primary schooling should not, however, obscure the needs for an overall policy of strengthening the provision of education, which includes secondary and education at the university level. Table 38 indicates clearly that such an approach is essential to the fight against poverty in the country. Indeed, the gains of education in reducing income poverty are substantial for heads of households with secondary and higher education. This policy will naturally stimulate the need for training teachers.

245. Regarding girls and education, the current trend indicates that there are fewer girls than boys, although remarkable progress has been observed. The ratio of girls to boys in primary school rose from 80 percent in 2000 to 91 percent in 2005. A more systematic analysis of the determinants of demand for education generally indicates that these efforts

\footnotetext{
${ }^{14}$ Building new primary school classrooms.

${ }^{15}$ This assessment is based on the GPI (parity index) and the gross enrollment rate.
} 
of equity must be maintained (see Table 38). The results show that the girls were still less likely than boys to have access to education in 2006.

\subsection{Improving access to healthcare}

246. The goal is to set up an effective health system to expand health coverage to the entire country and to enable the people to access quality healthcare. With this in mind, four general objectives were identified. They are: (i) reducing maternal and neonatal mortality rates; (ii) reducing infant and child mortality rates; (iii) reducing the prevalence of transmissible and non-transmissible diseases; and (iv) improving the performance of the national health system.

\section{Status update on the principal causes of morbidity and mortality}

247. Special emphasis is placed on several health targets; they are children under five and pregnant women. Here, the priority is clearly fighting malaria, tuberculosis and HIV/AIDS. The choice of these targets is dictated by the health situation in Burundi, characterized by high morbidity and mortality rates that affect children under five and pregnant women in particular. The maternal mortality ratio is 615 per one hundred thousand live births (MICS 2005 Survey), while the perinatal mortality rate is 34 per thousand in the health facilities (2007 PNSR Activity Report). According to the 2005 MICS Survey, the mortality rate for children under five is 176 per thousand. This makes the rate among the highest in Sub-Saharan Africa. The principal diseases responsible for this high morbidity and mortality rate are malaria, diarrheal diseases, acute respiratory infections, malnutrition and AIDS.

248. Malaria is still widespread in Burundi as an endemic epidemic. It is the worst public health problem because it continues to be the leading cause of mortality and morbidity in the country. According to the 2006 Annual LMTC Program Report, over two million cases $(2,265,970$ cases $)$ of malaria were recorded in the health centers. This disease alone accounts for 77 percent of morbidity cases treated in the health centers if only the diseases that are included in the Integrated Disease Surveillance and Response (IDSR) program are taken into account. The new outbreak of malaria led to adopting a new artemisinin-based treatment protocol in November 2003. However, to date there is no intermittent treatment for pregnant women who must use insecticide-treated nets as a prevention method. In 2006 about 1,102,800 nets were distributed. The usage rate for these nets was 16.2 percent for children under five. For 2007 the overall usage rate is 29.42 percent.

249. The tuberculosis burden is considerable as well. Persons affected can be found in every strata of the population, but the most affected age group is between 15 and 44 years old. The groups most exposed to the diseases are prisoners, refugees, malnourished individuals, and individuals who are HIV+. The 2006 Annual PNLT Report shows that nearly 7,000 new cases of tuberculosis (all types combined) are discovered each year. In these new cases, there are more than 3,000 cases of smear-positive pulmonary tuberculosis, which amounts to an annual incidence of 100/100,000 persons. Tuberculosis is the leading opportunistic infection in PLWHA, yet no surveys on the scope of the TB/HIV co-infection problem have been performed in Burundi. The National Program to 
Combat Leprosy and Tuberculosis (PNLT) has just begun a survey on HIV prevalence in tuberculosis patients. Early results show that the co-infection rate is 26 percent.

250. Diarrheal diseases are the third leading cause of morbidity in children under five. The lack of sanitation and hygiene, the growing insufficiency of drinking water, and the poor human waste disposal system largely explain the high prevalence of diarrheal diseases in the population in general and in children under five in particular. Cholera and bacillary dysentery are often rampant in endemic and epidemic form.

251. The rate of underweight children less than five years old in Burundi has improved since 2007 and is still low. It declined from 39.2 percent in 2005 to 35.2 percent in 2007. In rural areas, the rate is 40.8 percent versus 21.8 percent in urban areas. In the same period, the slow growth rate in children under five was down from 52.5 percent to 46 percent. Since 2005, the acute malnutrition rate has been held below 10 percent (the critical threshold). In 2007 it was 5.6.

Table 15: Nutritional status of children under five by province (\%)

\begin{tabular}{|l|c|c|c|c|c|c|}
\hline \multirow{2}{*}{$\begin{array}{l}\text { Province of } \\
\text { residence }\end{array}$} & \multicolumn{3}{|c|}{ Underweight } & \multicolumn{3}{c|}{ Slow growth } \\
\cline { 2 - 7 } & Overall & Moderate & Severe & Overall & Moderate & Severe \\
\hline Bubanza & $\mathbf{3 8 . 7}$ & 30.3 & 8.4 & $\mathbf{4 3 . 2}$ & 22.6 & 20.6 \\
\hline Bujumbura Rural & $\mathbf{3 2 . 0}$ & 24.2 & 7.8 & $\mathbf{4 0 . 6}$ & 24.6 & 16.0 \\
\hline Bururi & $\mathbf{3 1 . 7}$ & 29.7 & 2.1 & $\mathbf{3 7 . 9}$ & 24.8 & 13.1 \\
\hline Cankuzo & $\mathbf{3 3 . 0}$ & 20.8 & 12.3 & $\mathbf{3 9 . 6}$ & 23.6 & 16.0 \\
\hline Cibitoke & $\mathbf{3 2 . 5}$ & 27.0 & 5.5 & $\mathbf{5 2 . 0}$ & 29.5 & 22.5 \\
\hline Gitega & $\mathbf{3 3 . 3}$ & 25.2 & 8.1 & $\mathbf{5 0 . 2}$ & 31.1 & 19.1 \\
\hline Karusi & $\mathbf{4 0 . 0}$ & 33.3 & 6.7 & $\mathbf{4 8 . 2}$ & 31.3 & 17.0 \\
\hline Kayanza & $\mathbf{3 8 . 8}$ & 30.4 & 8.4 & $\mathbf{5 2 . 3}$ & 28.4 & 23.9 \\
\hline Kirundo & $\mathbf{3 4 . 8}$ & 25.9 & 8.9 & $\mathbf{4 9 . 4}$ & 25.3 & 24.1 \\
\hline Makamba & $\mathbf{1 3 . 0}$ & 10.4 & 2.6 & $\mathbf{3 0 . 8}$ & 24.4 & 6.4 \\
\hline Muramvya & $\mathbf{2 8 . 7}$ & 17.0 & 11.7 & $\mathbf{3 7 . 2}$ & 20.2 & 17.0 \\
\hline Muyinga & $\mathbf{4 5 . 5}$ & 34.3 & 11.1 & $\mathbf{5 6 . 2}$ & 29.0 & 27.6 \\
\hline Mwaro & $\mathbf{3 9 . 7}$ & 33.3 & 6.3 & $\mathbf{4 2 . 9}$ & 27.0 & 15.9 \\
\hline Ngozi & $\mathbf{3 5 . 3}$ & 28.1 & 7.2 & $\mathbf{4 6 . 3}$ & 30.0 & 16.3 \\
\hline Rutana & $\mathbf{4 2 . 3}$ & 29.8 & 12.5 & $\mathbf{5 1 . 0}$ & 24.0 & 26.9 \\
\hline Ruyigi & $\mathbf{3 7 . 6}$ & 29.3 & 8.3 & $\mathbf{4 7 . 1}$ & 27.4 & 19.7 \\
\hline Bujumbura Mairie & $\mathbf{2 1 . 1}$ & 16.1 & 5.0 & $\mathbf{2 6 . 3}$ & 15.0 & 11.3 \\
\hline $\begin{array}{l}\text { Total for the } \\
\text { country }\end{array}$ & $\mathbf{3 5 . 2}$ & $\mathbf{2 7 . 3}$ & $\mathbf{7 . 9}$ & $\mathbf{4 6 . 0}$ & $\mathbf{2 6 . 6}$ & $\mathbf{1 9 . 4}$ \\
\hline Source: Nationyyyyy \\
\hline
\end{tabular}

Source: National Nutrition Survey performed by the ISTEEBU and UNICEF in 2007.

\section{Activities and results}

252. The government faces the following two major challenges for providing quality care in sufficient quantity: (i) increasing access to care for the people; and (ii) improving the performance of the national health system. By deciding to fully subsidize maternal care and care for children under five, the government has made reducing maternal and infant mortality one of its public health priorities. Free care has significantly increased the use of health services. Free care for Persons Living with HIV (PLWHA) and for tuberculosis patients, as well as the fact that anti-malaria medicines are highly subsidized, has also contributed to improving access to healthcare. 
253. These measures were followed directly by an increase in deliveries in healthcare environments, up from 22.9 percent in 2005 to 41 percent in 2007 (2007 PNSR Activity Report). However, access to maternity healthcare is still limited. Only about 66.1 percent of health centers have a maternity ward. There is also the fact that only 12 percent of staff receives practical training in basic obstetrical care.

254. The government has carried out other activities to bolster health services. In particular, it strengthened the early monitoring and warning system for the endemic diseases, which are polio, neonatal tetanus and measles, or the potentially epidemic diseases, which are cholera, meningitis and tuberculosis. Along those same lines, the growing number of immunization campaigns against the endemic diseases has brought about a considerable improvement in protecting children. In 2007 vaccine coverage was 97 percent for BCG, 93 percent for OPV3, 94.3 percent for DTDHib/HepB, 93.7 percent for measles, and 93.5 percent for Vitamin A supplements in children less than one year old. At the national level, total vaccine coverage remains above 80 percent. Moreover, the health authorities organized immunization campaigns against cerebral-spinal meningitis and are requiring immunization for contacts suspected of having rabies.

255. Encouraging progress has been made in the areas of maternal health and fighting malnutrition. In promoting maternal health, major progress is being made, in particular in the use of contraception. The contraceptive prevalence rate reached 4.7 percent versus performance levels that were much lower in prior years. However, this rate is still very low for reducing maternal and neonatal mortality. In fighting malnutrition, the activities that were planned have generally been carried out. First, the micronutrient supplementation programs have been carried out and expanded, and maternal breastfeeding and supplementary foods have been promoted. Second, the rate of use of iodized salt has been increased and stood at 98 percent in 2006 .

\section{Financing for priority programs}

256. The government has made considerable effort to raise funds, both domestically and abroad, needed to finance the health sector. With these funds health facilities were renovated and outfitted and drugs were made available, while health staffing levels were increased.

257. Resources to fund the health sector come from the national budget, foreign aid, health insurance and direct payments by users. The average cost of the program is 50 million dollars per year. In 2007 Burundi committed five million dollars for the regular budget and 7.4 million dollars for the special investment budget. Health funding from the government's own resources increased substantially over the last two years. With HIPC funding, the budget more than doubled to two 2 percent of GDP and 6 percent of the government's total budget. However, Burundi is still the country in Sub-Saharan Africa with the lowest percentage of government expenditures allocated to health per capita, at slightly less than two dollars per inhabitant in 2006. 
Table 16: Domestic financing through the government budget

\begin{tabular}{|l|c|c|c|c|}
\hline & $\mathbf{2 0 0 4}$ & $\mathbf{2 0 0 5}$ & $\mathbf{2 0 0 6}$ & $\mathbf{2 0 0 7}$ \\
\hline Health budget as a \% of total government expenditures & 3 & 2 & 7 & 6 \\
\hline Health budget as a \% of GDP & 1 & 1 & 3 & 2 \\
\hline Annual change in the health budget as a \% & 19 & -11 & 277 & -23 \\
\hline Health budget per inhabitant in US\$ & 1 & 1 & 2 & 2 \\
\hline
\end{tabular}

Source: Ministry of the Economy, Finance and Development Cooperation

258. Foreign aid is the principal source of funding for the health sector and amounted to 11.2 dollars per inhabitant in 2006. However, Burundi receives less aid than other countries ${ }^{16}$ in a post-conflict situation, except for the year 2005, when the total amount of ODA received per inhabitant was slightly greater than the average amounts received in the other countries of Sub-Saharan Africa (SSA). Foreign aid to support the health sector in Burundi is in a transition phase in which emergency aid should give way to sustainable financing for the system.

Chart 4: Distribution of aid between donors and NGOs.

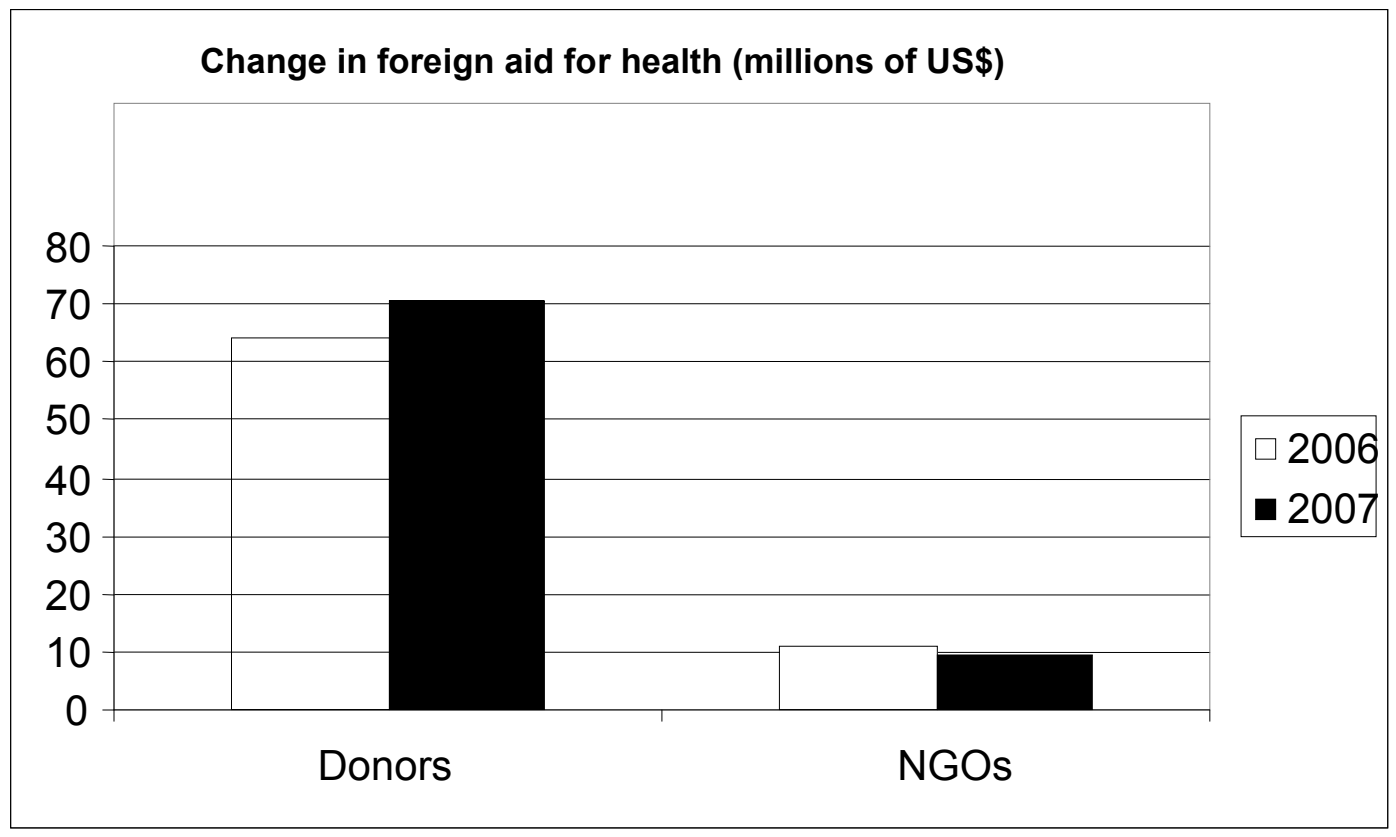

Source: Ministry of Public Health and the Fight Against AIDS

259. Aid comes in many forms. It is either in kind or in the form of loans and public grants (budgetary support). The partners (donors, autonomous agencies, national and international NGOs, foundations and churches) disburse substantial resources directly. One-quarter of funding from donors allocated to the sector was in the 2006 budget, while the remaining three-quarters were not in the budget.

\footnotetext{
${ }^{16}$ In 2005, Sierra Leone, Rwanda and Liberia received $\$ 62, \$ 64$ and $\$ 72$ in foreign aid per inhabitant respectively.
} 


\section{Constraints and outlook for the future}

260. The following constraints interfered with achieving the goals set in the PRSP. They are: (i) the insufficiency and poor distribution of human resources; (ii) the poor coverage the country has in health infrastructure and equipment; (iii) the poor technical and institutional capacities; (iv) lack of funding; and (v) cumbersome procedures for disbursing funds.

261. The outlook for the sector can be summarized by implementing on an urgent basis certain reforms that are essential for achieving the PRSP objectives. They are:

(i) The health sectoral approach;

(ii) Preparing a human resources development plan;

(iii) Setting up the health districts;

(iv) Strengthening the drug distribution systems;

(v) Continuing to renovate and outfit the care facilities; and

(vi) Strengthening the statistics system.

4.3 Improving access to drinking water, hygiene, sanitation and decent housing

262. The four key components of fighting poverty are: (i) access to drinking water, hygiene and sanitation; (ii) improving housing and rational urban planning; (iii) supporting vulnerable groups; and (iv) gender advancement.

\section{Access to drinking water, hygiene and sanitation}

263. The goal is essentially: (i) to improve access to drinking water for communities in the most poorly served zones in the rural and peri-urban area, and vulnerable groups; (ii) to improve hygiene (water and sanitation) in the area of health and education; and (iii) to better involve the communities in planning and organizing water and sanitation systems.

264. With partner support the government has made considerable efforts to make drinking water increasingly accessible to the majority of the population. Nevertheless, more work needs to be done, since according to the 2005 MICS Survey, 64.3 percent of households are using improved sources of drinking water and 31.7 percent of households are using upgraded sanitary facilities. The drinking water supply and sanitation programs carried out in rural areas dealt with upgrading the sources of water, building and renovating water supply systems and public latrines, and distributing family latrines, followed by hygiene education sessions.

265. Government priorities for the drinking water sector are renovating the infrastructure, reestablishing access to the service, and expanding it. In urban areas, this involves renovating the REGIDESO facilities, finding satisfactory yields for the distribution system in order to meet the demand of the displaced populations, ${ }^{17}$ and having the refugees return. In rural areas, infrastructure renovation and development must go hand-in-hand with improvements in management. This will require revitalizing the

\footnotetext{
${ }^{17}$ Most are in the cities.
} 
communal management bodies, increasing awareness of the cost of the service, and seeking a system appropriate for recovering costs.

266. In terms of organization, the number of sanitation workers and hydraulic engineers were increased, and training sessions were organized for them. These sanitation workers are already carrying out awareness campaigns with the people as well as disinfection and disinfestation projects. In this work, priority is placed on public institutions, such as schools, health centers and hospitals. As delivery is taken of the water supply facilities, management of the facilities is handed over to the people of the communes that are involved through communal water management bodies (RCE).

267. For better planning in this area of activity, surveys were conducted on drinking water, housing and waste disposal. The studies addressed drinking water requirements and the availability of sources of water that can be developed, possibilities for water supply using a gravity system or wells, and the status of health and sanitation infrastructures in public institutions and in schools in particular.

268. In urban areas, drinking water has been supplied to Bujumbura Mairie and to 22 centers in the hinterlands with 35,002 connections and 600 standpipes. ${ }^{18}$ Urban growth is strong, mainly due to the influx of displaced persons and the return of the refugees. REGIDESO is unable to meet the demand for connections due to a lack of material resources. ${ }^{19}$ Drinking water production capacity is satisfactory in the capital city, with over 160 liters available per day and per inhabitant. However, most distribution is by pumping, and the flow reversal stations need to be upgraded. The hydraulic operation of the network is far from optimal because there are no more pressure stages; this worsens the leaks. The density of the distribution network $(550 \mathrm{~km}$, or $1.1 \mathrm{~m}$ per inhabitant $)$ is low. REGIDESO has made some small expansions in the water network for a total length of $11,558 \mathrm{~m}$.

269. REGIDESO produced 39 million $\mathrm{m} 3$ of water in the year 2007,31 million $\mathrm{m} 3$ of which were for the city of Bujumbura, which alone accounts for 80 percent of this production.

270. Production was 16 percent higher than in 2006, essentially for the following two reasons: the energy shortfall that Burundi experienced in 2006, and high rainfall amounts in 2007. Losses are high, at about 46 percent, and they are due to: (i) problems with the meters (including production); (ii) illegal connections; (iii) dilapidated water mains and connections; and (iv) excessive pressure in low-lying areas. REGIDESO is seeking to reduce these losses from 46 percent to 20 percent between 2006 and 2013. The development of total drinking water production and customers in this sector in Bujumbura and in the regions is shown in the two tables below.

\footnotetext{
${ }^{18}$ Many of them are no longer operating.

${ }^{19}$ REGIDESO makes about 1,000 connections per year.
} 
Table 17: Drinking water production (m3).

\begin{tabular}{|l|r|r|r|r|r|}
\hline Center & \multicolumn{1}{|c|}{$\mathbf{2 0 0 3}$} & \multicolumn{1}{c|}{$\mathbf{2 0 0 4}$} & \multicolumn{1}{c|}{$\mathbf{2 0 0 5}$} & \multicolumn{1}{|c|}{$\mathbf{2 0 0 6}$} & \multicolumn{2}{c|}{$\mathbf{2 0 0 7}$} \\
\hline Bujumbura & $25,313,828$ & $27,883,675$ & $28,166,589$ & $27,539,004$ & $31,256,807$ \\
\hline Région Est & $1,741,578$ & $1,627,984$ & $1,384,608$ & $1,656,412$ & $2,151,529$ \\
\hline Région Sud & 799,264 & 709,783 & 639,433 & 816,355 & $1,807,074$ \\
\hline Région Nord & $1,377,026$ & $1,378,872$ & $1,209,193$ & $1,059,645$ & $1,634,543$ \\
\hline Région Ouest & $1,513,518$ & $1,789,500$ & $1,676,871$ & $1,886,702$ & $2,065,730$ \\
\hline Total & $\mathbf{3 0 , 7 4 5 , 2 1 4}$ & $\mathbf{3 3 , 3 8 9 , 8 1 4}$ & $\mathbf{3 3 , 0 7 6 , 6 9 4}$ & $\mathbf{3 2 , 6 4 5 , 8 7 5}$ & $\mathbf{3 8 , 9 1 5 , 6 8 3}$ \\
\hline
\end{tabular}

Source: Ministry of Water and Energy

Table 18: Change in drinking water subscribers

\begin{tabular}{|l|r|r|r|r|r|r|r|}
\hline Center & \multicolumn{1}{|c|}{$\mathbf{2 0 0 2}$} & $\mathbf{2 0 0 3}$ & \multicolumn{1}{c|}{$\mathbf{2 0 0 4}$} & \multicolumn{1}{|c|}{$\mathbf{2 0 0 5}$} & \multicolumn{1}{|c|}{$\mathbf{2 0 0 6}$} & \multicolumn{1}{c|}{$\mathbf{2 0 0 7}$} & Growth rate (\%) \\
\hline Bujumbura & 19,237 & 20,180 & 21,201 & 21,784 & 24,308 & 24,435 & 11.5 \\
\hline Région Est & 1,364 & 1,470 & 1,548 & 1,616 & 1,742 & 1,911 & 7.7 \\
\hline Région Sud & 2,204 & 2,521 & 2,671 & 2,765 & 3,039 & 3,357 & 9.9 \\
\hline Région Nord & 1,438 & 1,595 & 1,675 & 1,705 & 1,963 & 2,257 & 15.1 \\
\hline Région Ouest & 2,133 & 2,231 & 2,508 & 2,654 & 2,829 & 3,042 & 6.5 \\
\hline $\begin{array}{l}\text { Large internal } \\
\text { consumer }\end{array}$ & & & & 21 & 21 & & 0 \\
\hline Total & $\mathbf{2 5 , 1 5 0}$ & $\mathbf{2 6 , 4 7 4}$ & 28,274 & 30,545 & 33,902 & 35,002 & 10.9 \\
\hline
\end{tabular}

Source: Ministry of Water and Energy

271. In rural areas, drinking water supply is still tenuous. The problems are a lack of access to drinking water and decent sanitation systems and poor personal hygiene and environmental practices. These insufficiencies are the leading causes of mortality and morbidity in children under five. This is a major public health problem.

272. In 2007 a few water supply and sanitation systems were built. ${ }^{20}$ Using HIPC funding, the DGHER built ten drinking water supply systems (DWSS) in the provinces of Bubanza, Cibitoke, Gitega, Bujumbura Rural, and Ngozi. They are: the Muyebe DWSS in the commune of Musigati; the Ruce DWSS in the commune of Mabayi; the Burenza DWSS in the commune of Mubimbi; the Gisagara DWSS in the commune of Mubimbi; the Ruyaga DWSS in the commune of Kanyosha; the Mugina DWSS in the commune of Mugina; the Mutwenzi DWSS in the commune of Gitega; the Gacekeri DWSS in the commune of Ngozi; the Mureke DWSS in the commune of Ngozi; and the Buhanda DWSS in the commune of Mwumba. The PTEPEC, Economic Rehabilitation Loan, IFAD and ABUTIP projects built other drinking water and sanitation systems.

${ }^{20}$ In 2006 performance studies of building water supply facilities were conducted for certain provinces only (Cibitoke, Bubanza, Bujumbura Rural, Gitega and Ngozi) and communal hydraulic engineers were trained (Cibitoke, Bubanza, Bujumbura Rural, Ngozi and Mwaro). Two hydraulic engineers were trained per commune. 


\section{Housing and urban development}

273. In general, Burundian households live in their own homes (especially in rural areas), since about 93 percent own their homes. This percentage has held nearly steady for the last ten years. However, the quality of these housing units is tenuous, since just 57 percent have sheet metal or tile roofing. Burundi is an under-urbanized country because the cities were founded recently and are not really attracting people from the countryside to generate ongoing rural exodus movements. Moreover, the decade of socio-political crisis unfortunately led to major losses of human life, caused people to be displaced, and resulted in massive destruction of housing units.

274. In the area of housing, Burundi's main challenge is to increase the supply of land, real-estate production, and infrastructure, while expanding access to basic services. In the area of urban development, the challenges in the country are threefold: (i) high population density; (ii) a very low rate of urbanization; and (iii) meeting the vital needs of more urban dwellers. To deal with these challenges, the government enlisted UNDP and UN-HABITAT support beginning in 2006 for a participatory process to prepare its housing and urban development policy. At this time Burundi has a comprehensive assessment study and a National Policy Letter in the sector.

275. This policy seeks to achieve two overall objectives by 2020. First, it seeks to give Burundi a balanced urban framework that is well structured and that radiates throughout a region as a set of socioeconomic development centers. Second, the goal of the government policy is to give each Burundian access to adequate housing and quality basic services. Implementing this policy requires establishing a strategy and action plan and preparation will begin soon. Moreover, most Burundians are still living in the countryside. The urbanization rate is 13 percent in 2007. It was 11 percent one year earlier. This recent trend denotes a very rapid urban growth rate. Chart 5 that follows highlights this near-exponential growth.

Chart 5: Urbanization trends in Burundi

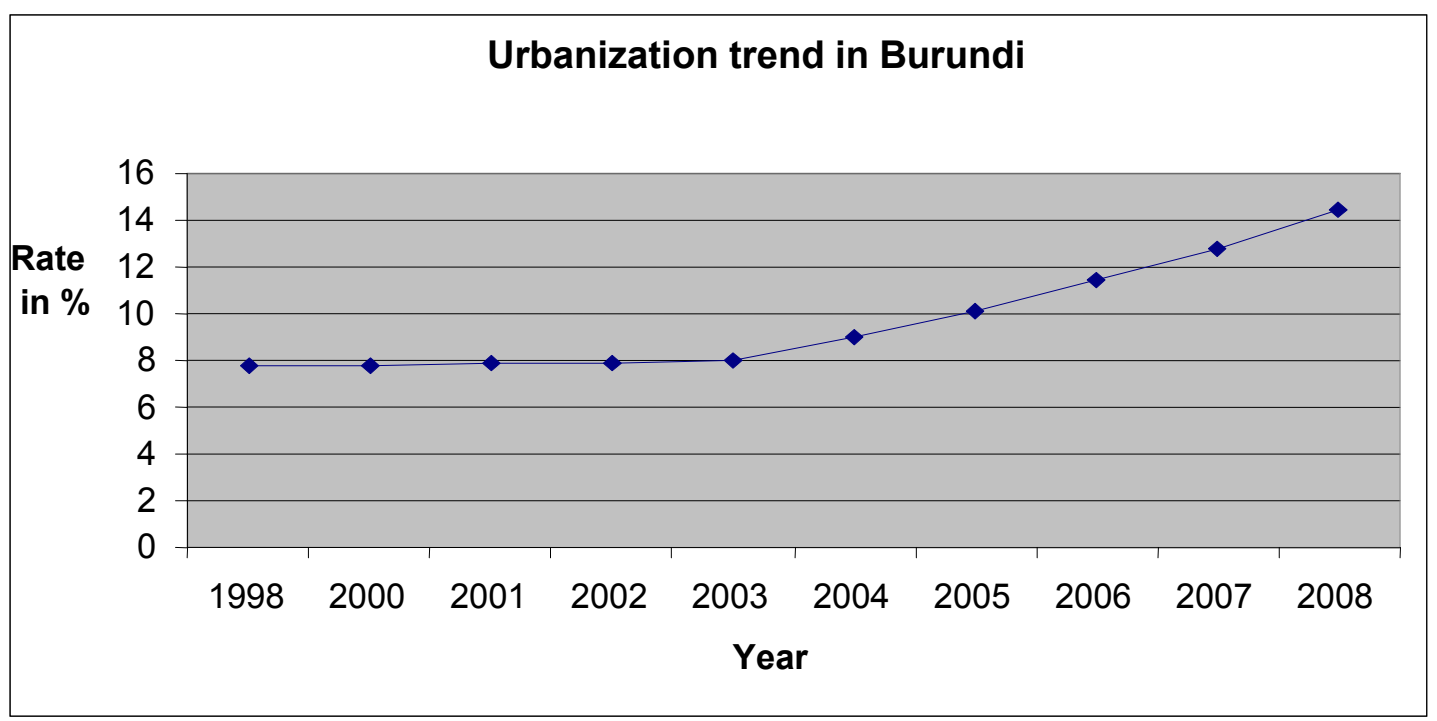

Source: Ministry of the Environment, Land Development and Public Works 
276. Most of the secondary centers are still entities characterized by a few administrative, commercial and artisanal activities. Agriculture plays a major role in the economy of these secondary centers. Informal areas (quartiers spontanés) have proliferated in these centers. Sanitation infrastructures are also lacking, basic services are difficult to access, existing infrastructure is not maintained, the communes have poor management skills, and planning and urban management tools are lacking.

277. In general, the salient issues of the urban planning and housing sector are:

(i) The lack of a space management policy, taking space and population constraints into account;

(ii) The fact that there is little government land inside and outside the perimeters of the urban centers, and household income is low in relation to the cost of housing;

(iii) Limited capacities in the area of land development, urban planning and management, including insufficient skilled human resources, and the lack of the necessary technical and legal tools;

(iv) The rural exodus of youth, seeking greater security and jobs in the urban centers;

(v) The increasing cost of construction materials;

(vi) The massive destruction of socioeconomic infrastructures during the 1993 crisis.

278. Efforts are being made to expand in the cities, both in Bujumbura and in the hinterlands. The authorities built several developments of lots and made parcels available for construction in Bujumbura (Carama, Gasekebuye, Kanyosha) and in certain urban centers in the hinterlands (Cibitoke, Gitega, Ngozi, Makamba, Mwaro, Ruyigi).

279. With regard to the large urban metropolitan areas, the communal urban development commissions have already been created and are supervising the development and marking of the sites that were selected. The rivers that pass through the city of Bujumbura are also being developed to preserve the housing units and infrastructures that are being seriously threatened. Nevertheless, efforts must still be made, especially in the Vugizo and Rubanza gullies.

\subsection{Support for vulnerable groups}

280. In June 2007, the Ad Hoc Integrated Commission for Repatriation and Reintegration was created. This is an important accomplishment, and from now on it will better coordinate responses to the repatriation process. In September 2007 this Commission adopted an action plan for repatriation and reintegration. It brings together representatives of the government, United Nations agencies, donors, and NGOs active in repatriation and reintegration. The latter is under MSNRDPHG supervision. In partnership with the Burundian authorities and the United Nations agencies, the UNHCR allocated US\$17 million in 2007 for distributing return packages, financial allocations and national identity cards, monitoring visits to repatriated households, mediation of land conflicts and legal aid, microcredit projects, building shelters, and reforestation. The repatriation of Burundian refugees continues at a high level. Since 2002, more than 
400,000 have returned from exile. Trends in the number of repatriates are illustrated in Table 19 below.

Table 19: Trends in the number of repatriates

\begin{tabular}{|l|c|}
\hline Year & Number \\
\hline 2002 & 45,623 \\
\hline 2003 & 90,191 \\
\hline 2004 & 98,440 \\
\hline 2005 & 72,056 \\
\hline 2006 & 48,123 \\
\hline 2007 & 41,718 \\
\hline Total & $\mathbf{3 9 6 , 1 5 1}$ \\
\hline
\end{tabular}

Source: Ministry of National Solidarity

281. Self-construction of shelters by repatriates is a key activity for reintegrating the repatriates. In 2007 Burundi took in 9,721 people expelled from Tanzania, for a total of 15,609 since May 2006. ${ }^{21}$ In general, all homeless repatriates are considered vulnerable and thus are eligible for this program. Nevertheless, due to limited means, households that are extremely vulnerable are given priority. This is the case of heads of households who are women, the elderly, and persons with disabilities. For building shelters, the UNCHR habitat program and those of its partners built 6,750 houses in $2007 .{ }^{22}$ For homeless persons in the repatriate hosting communities, these programs have built 8,000 houses, ${ }^{23}$ or 20 percent of the total.

282. Taking care of the indigent, vulnerable children and refugees required dealing with additional urgent requirements. First, the crisis considerably increased the number of indigents and street children. In this context, more than 7,600 indigents received assistance for healthcare and for obtaining food and non-food supplies. The street children did not receive the assistance necessary for their resocialization, but this cannot be postponed for much longer. Also, Burundi is hosting 32,545 refugees and asylum applicants. There are 31,904 Congolese who have settled in the camps in Gihinga (Mwaro), Gasorwe (Muyinga) and Musasa (Ngozi), and 11,755 urban refugees. There are also 233 Rwandans as well in the Giharo camp in Rutana. All of them received various types of assistance that meet assistance and protection standards.

283. The return movement accelerated with the closing of the Burundian refugee camps in Tanzania and the scheduled return of refugees exiled since 1972. These upheavals resulted in starting programs to increase hosting, reintegration and schooling capacities for the repatriated children. Thus, the government first carried out efforts to identify new sites for resettlement before it adopted support measures for reintegrating the repatriates and other landless victims. For schooling for the repatriated children,

\footnotetext{
${ }^{21}$ Since 2002, through its programs, the UNDP has contributed to building 1,900 houses for vulnerable households (repatriates, internally displaced persons and vulnerable households from the hosting communities).

${ }^{22}$ These new houses supplement the total number of 51,153 houses already built between 2003 and 2006.

${ }^{23}$ In 2008, the UNHCR plans to build 14,300 houses, or twice as many as in 2007.
} 
specific measures were taken to accelerate their learning of the everyday languages with United Nations support.

284. Since May 2006 the government of Burundi, in partnership with UNICEF, has also assisted 21,296 Burundians expelled from Tanzania. These persons were given reintegration support just as the repatriates, notably in the area of housing and schooling.

285. Assistance to vulnerable persons was also provided by continuing programs to improve their socioeconomic conditions. Since 2005, through its Disaster Reintegration/Rehabilitation and Poverty Reduction Program (PRRSLP), the UNDP has contributed to improving the socioeconomic framework for victims and vulnerable persons such as repatriates and internally displaced persons from the hosting communities. The purpose is to renovate and also build schools and health centers, and to facilitate access by the beneficiaries to the means and factors of production. In 2007, the WFP also assisted 7,022 vulnerable persons of this type through the Social Institutions (SI).

\subsection{Gender advancement}

286. To the credit of gender advancement, it should be noted that substantial progress has made in terms of the participation of girls in the educational system ${ }^{24}$ and in women's empowerment. With regard to schooling for girls, it should be noted that less than 80 percent of all girls attended school in 2000 compared to boys, 91 percent of whom attended school in 2006-2007. However, less rapid progress has been observed in secondary and higher education. This has a direct impact on women's participation in the country's socioeconomic activities. Regarding women's empowerment, it should be underscored that the percentage of women in political and economic decision-making positions has grown steadily over these last few years. To strengthen this encouraging trend, the constitution in effect in Burundi consecrates women's participation in all the institutions of the legislative and executive branches. Thus, nearly 35 percent of ministerial positions are held by women, while the percentage of women with access to political and economic decision-making positions ${ }^{25}$ was up from 11.2 percent in 2003 to over 20 percent in 2007.

287. Due to its cross-cutting nature, the results of taking gender into account are to be assessed in every socioeconomic sector. Thus, the specific projects, which have been carried out for the advancement of women, are found essentially in the following six areas:

(i) Education: Documents were prepared for the purpose of more effectively taking the gender dimension into account, while manuals that focus on training of paralegals were prepared to support paralegal knowledge of women's rights.

\footnotetext{
${ }^{24}$ The notion of gender is cross-cutting because it is found in nearly every axis of the PRSP. Here, we focus solely on education, which is the key for development and access to most of the opportunities that are offered in life.

${ }^{25}$ In the previous institutions, women had never risen above $20 \%$ during the transition period.
} 
(ii) Strengthening the economic power of women: Many types of support were provided to women's groups to promote income-generating activities, while training sessions on preparing and managing microprojects were organized for girls and women. In this context, microcredits were given to women's associations, in particular to facilitate access to agriculture and livestock inputs, and to encourage girls that have acquired skills to become professionals and hence achieve economic self-sufficiency. UNIFEM established a fund in the amount of $\$ 800,000$ to contribute to strengthening women's access to credit.

(iii) Support for the different players in promoting gender equality: a study on punishing the crime of rape in Burundi was performed by the Association of Women Lawyers.

(iv) Strengthening CDF capacities: the activities carried out aim to train and hire psychosocial workers and to acquire educational materials.

(v) Translation, simplification and dissemination of existing texts of laws and codes to promote the protection of women's rights: about 156 works are available, while the report on the technical review of the status update on harmonizing the Code of Persons and the Family and other instruments have been completed. 


\section{THE FIGHT AGAINST HIV/AIDS}

\subsection{Status of knowledge of the virus in Burundi in 2005}

288. The population of Burundi has been made aware of the scourge of AIDS through various activities carried out by the stakeholders in the public sector and civil society. However, an analysis of the general status of the virus over a reference year is essential to judge the progress that has been made and to evaluate the next stages. The data used for this purpose come from the 2005 MICS Survey that UNICEF performed.

289. Three series of essential results should be noted with regard to the ambitious objectives of the national program to fight the pandemic over the next few years. First, the data that were collected show that many women from 15 to 49 years old (nearly 57 percent) were convinced that they were at serious risk of contracting the AIDS virus in 2005. Considerable differences are observed regarding the risk of contamination according to the level of education, marital status, region and place of residence of women. The most striking differences are primarily related to the level of education, which, numerically speaking, seems to be unfavorable to women who attended secondary school and the university.

Chart 6: Several results indicators for AIDS (women from 15 to 49 years old)

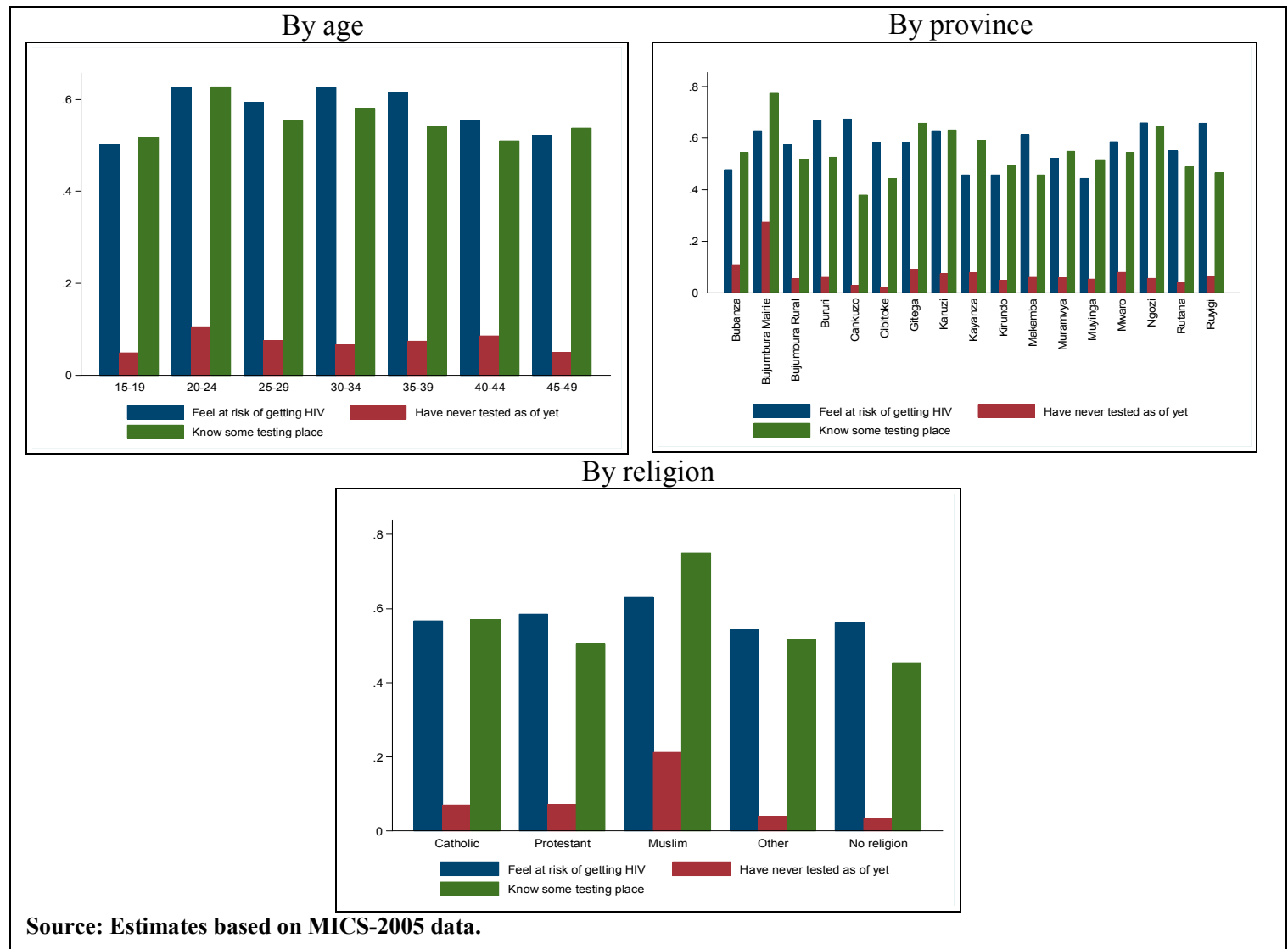

290. Moreover, it is useful to note that as the level of education of women rises, the respective rates of screening/voluntary testing and knowledge of a place near the home 
for testing rise substantially. Chart 6 illustrates perceptions by age, place of residence, and by religion.

291. Next, the review of the means of protection women use indicates that most women were still using somewhat archaic protection methods in 2005. Abstinence from sex (44 percent) and fidelity (47 percent) were by far the two "preferred" methods of Burundian women for protection against the risks of AIDS contamination. By contrast, the rate of condom use is insignificant. The most striking result, once again, is the impact of the level of education on women's behavior for the use of condoms. The usage rate of this modern means of protection varies from 1 percent for women without so-called formal education to 12.6 percent for women that attended university. This result shows a certain limit of the current policy of massive condom distribution. Consequently, women should be more targeted based on this educational criteria, and the awareness campaigns for women with less education should be strengthened a bit more.

292. Finally, it is worthwhile to analyze the level of knowledge women have of the AIDS pandemic in that year. First, it appears that knowledge of vectors for transmitting the disease between adults is surrounded by some confusion. For example, about 14 percent of women still believe that the virus can be transmitted by sorcery, and no less than 28 percent of them perceive that mosquitoes are an actual vector of transmission. Cause for still greater concern is that fact that just 61 percent of women were convinced in 2005 that the regular use of condoms provided significant protection from the disease. Second, a review of the indicators of channels for transmission from mother to child also points out major gaps. First, it should be noted that 79 percent of women believed that the virus could be transmitted during pregnancy, while the strict application of current protocols leads us to believe that this transmission has become unlikely. In this case also, the gaps in education levels result in major differences in perception that women have of this channel of transmission, but also of the risks of transmission during delivery and breastfeeding.

293. One important final point to be noted is society's general attitudes toward persons infected with AIDS. The estimates also seem to confirm the major confusion with regard to the appropriate way of perceiving and supporting an HIV+ person, whether that person is a close family member or not. Likewise, the data that were collected show that the full role of an HIV+ person in Burundian society was far from being implemented and well understood.

\subsection{Status of implementation of priority programs}

\section{HIV transmission prevention}

294. Awareness has been strengthened in three fundamental aspects. First, the governmental authorities have assigned two community organizers to each census hill. For the entire country, a total of 6,550 organizers have been made available. The activities carried out by the community organizers as well as the peer educators have brought about appreciable results in terms of prevention. Second, education on prevention behaviors through radio programs has expanded considerably. Thus, over two million persons-youths as well as adults (women and men)-were educated on prevention. To foster this offensive education, 147,575 persons were voluntarily tested, 
while a total of 31,790 cases of opportunistic infections were treated out of an expected 19,000 cases.

295. Prevention activities have been carried out on several fronts at the same time. First, condom distribution in the communes was accelerated through the community organizers. Second, a program for early HIV/AIDS screening, prevention ${ }^{26}$ and treatment has taken root in most hospitals and epidemiological surveillance sites in the country. In addition, the number of voluntary testing centers increased from 89 in 2002 to 151 in 2006. Third, with the support of the different players including UNICEF, mother-to-child HIV transmission prevention (MTCTP) has made progress. The number of sites dedicated to this program increased from just one in 2002 to 18, and then to 27 and 34 sites in 2005, 2006 and 2007 respectively. The country now has 51 MTCTP sites at which 1,102 HIV+ women and 796 newborns have been treated. Finally, prevention has taken place in the primary and secondary schools and in the universities through "Stop AIDS" clubs. There are now 972 of these clubs, in addition to the 129 "youth centers" that are operational in all the communes in the country.

\section{Chart 7: Trend in condom distribution}

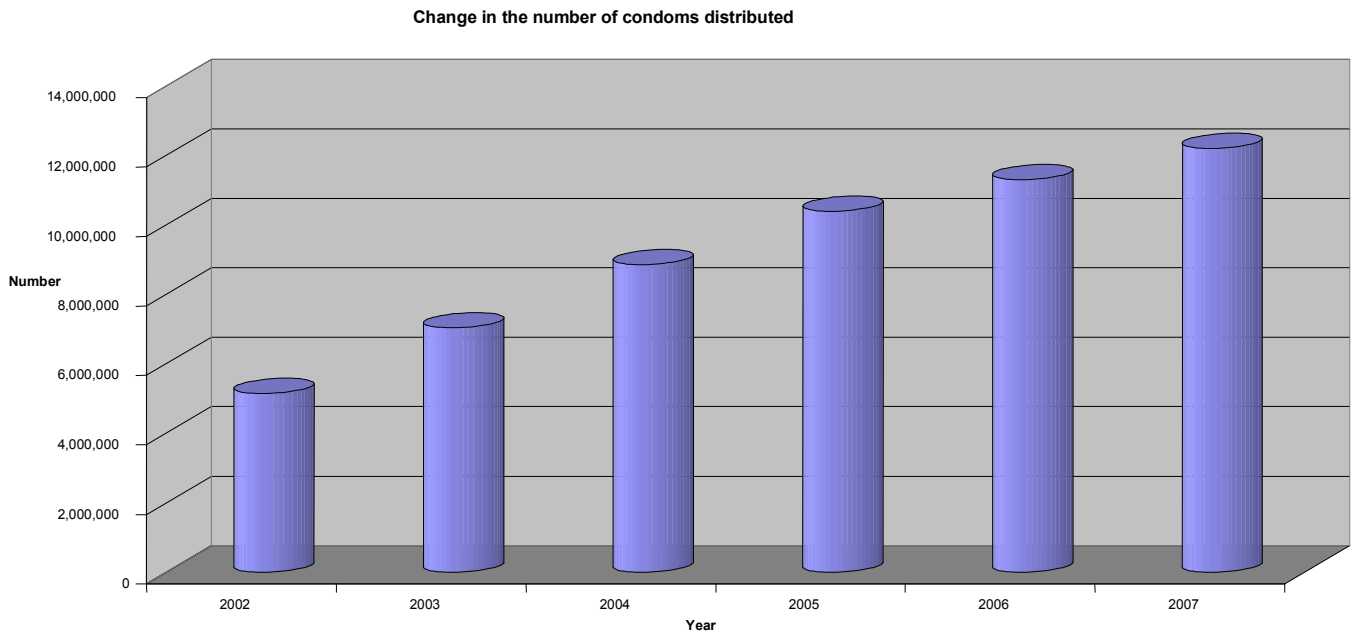

Source: CP/CNLS, 2007 Annual Report

296. Various governmental and nongovernmental centers have provided care to victims of sexual violence. The services offered included medical and psychosocial and legal services, not to mention protection from their attackers. These services observe the national service protocol which includes but is not limited to testing and providing postexposure treatment to prevent any risk of infection with the virus during the 48 hours after the attack.

\section{Services for patients infected with HIV}

297. To provide better services for PLWHA, Burundi prepared a national strategy for access to ARVs and care for opportunistic infections. To ensure that medical personnel

\footnotetext{
${ }^{26}$ Particularly among women 15 to 49 years old, and pregnant or HIV+ women.
} 
provide quality services, the authorities first implemented a program to train caregivers to treat opportunistic infections (OI). This program trained 175 physicians and 544 nurses. All of these appreciable means treated 38,146 cases of opportunistic infections in 2007 without much difficulty. As for treatment using ARVs, the number of PLWHA that have received this treatment was up from 600 in 2002 to 8,048 in 2006. For 2007, this increase continued, since the number of people involved stood at $10,865^{27}$ out of a projected 11,616; of these, 2,817 were new PLWHA. With these figures 93.5 percent of the initial goal was achieved. At the same time, the ARV treatment sites (there were five in 2002), increased to 39 throughout the country in 2007. Likewise, home care continued to be provided to 42,252 PLWHA. $^{28}$

298. Regarding psychosocial care for persons living with HIV, a total of 209 providers were trained in psychosocial services. Nearly 34,239 PLWHA were treated, while 12,769 PLWHA received nutritional support. However, we must still ensure that children who are victims of the pandemic can also obtain pediatric care appropriate for them, as well as adequate medical and nutritional assistance to supplement ARV treatment.

\section{Reducing the impact in persons affected by HIV}

299. The government realizes that the HIV/AIDS pandemic is causing poverty in households to worsen. That is why it is constantly on the alert to provide a national response to the HIV/AIDS pandemic and why it has set up systems to halt the spread of HIV and reduce its impact on individuals, families and communities. This mainly involves preventing the expansion of HIV/AIDS by permanent social support and appropriate care for persons already infected and affected by the pandemic.

300. To reduce the impact of HIV on the affected persons, the government advocates limiting new infections and treating persons infected and affected by HIV/AIDS. Thus, in an effort to improve the living conditions of PLWHA, a total of 75 sub-projects (62 of which are new) were financed for PLWHA. There are 8,915 PLWHA beneficiaries for 2007.

301. Regarding services for OVCs, school materials support was provided to 492,401 OVCs through UNICEF support, while 14,869 received medical assistance. Psychosocial assistance was provided to 26,382 OVCs and 10,319 OVCs received nutritional services. Moreover, it should be noted that 32,281 host families received agricultural inputs and that 2,865 OVCs were trained in various occupational fields.

302. In order to diversify the sources of funding for activities to fight AIDS, the Parliament of Burundi recently enacted the international air-ticket solidarity law. In the same area of laws enacted related to AIDS, the government enacted another law on the protection of PLWHA, and the implementing regulations are now being finalized.

\footnotetext{
27 ...including 1,195 children under 15 years old.

${ }^{28}$ Currently, in 2008, 48 accredited ARV treatment centers are operational.
} 


\section{Strengthening institutional capacities}

303. Faced with the growing AIDS pandemic, the government is convinced that it must do everything to succeed in testing people because knowing your HIV status is key to fighting AIDS. To this end, the political, administrative and religious leaders must continue to be constantly mobilized. Innovative strategies for mobilizing domestic and external resources are now being set up. In particular, for internal resources there are plans to include line items in the general government budget to fund AIDS control activities in the various sectoral units of the government.

304. Efforts are continuing to improve program coordination and effectiveness. In particular, a map of the players in fighting AIDS is being prepared. Moreover, it is now incumbent on all the players in the different sectors to report their activity to the Ministry in Charge of Fighting AIDS to establish an action partnership that better coordinates the efforts. These framing efforts resulted in a major improvement in the management and coordination of the National Program to Combat AIDS, which at the same time implemented the recommendations of the CNLS, CCM, GTO and the World Bank in this area. The matter of statistical information is also central to harmonizing efforts to achieve results. To strengthen the information system, the treatment sites now have the AIDS Info database and the staff has been trained to use it.

305. To achieve tangible results in testing, the government set up facilities to fight AIDS at the central level as well as the decentralized level. It also provided for different tools to better respond to the pandemic through its new 2002-2006 strategic plan whose accomplishments are undeniable. A new 2007-2011 action plan has just been launched with two clear goals: (i) to stop new infections and (ii) to efficiently provide care for persons infected and affected by HIV/AIDS.

306. However, many obstacles remain to ensure that the new strategy to fight AIDS is correctly implemented. There are three types of these obstacles:

a) The encouraging results of recent years in fighting AIDS are creating new challenges;

b) The current institutional framework is different than the one indicated in the 2007-2011 PSNLS and the one the government and its partners adopted;

c) The "multisectoral" aspect of fighting AIDS implies that action to fight HIV/AIDS must be carried out through all the sectors in national activity (sectoral ministries). The activities carried out in these ministries are insufficiently coordinated. 


\section{MACROECONOMIC PERFORMANCE}

\subsection{The real sector}

307. The annual GDP growth rate the PRSP used was 6 percent over a period of three years. This growth was made possible by implementing the structural reforms as planned in the first PRGF and by the increased availability of financial resources in the form of budget support. The actual growth rate in 2007, 3.2 percent, was highly dependent on the performance of the coffee sector, whose output fell to 8,000 metric tons from 30,000 metric tons in 2006.

Table 20: Change in the real GDP growth rate (in 1996 prices).

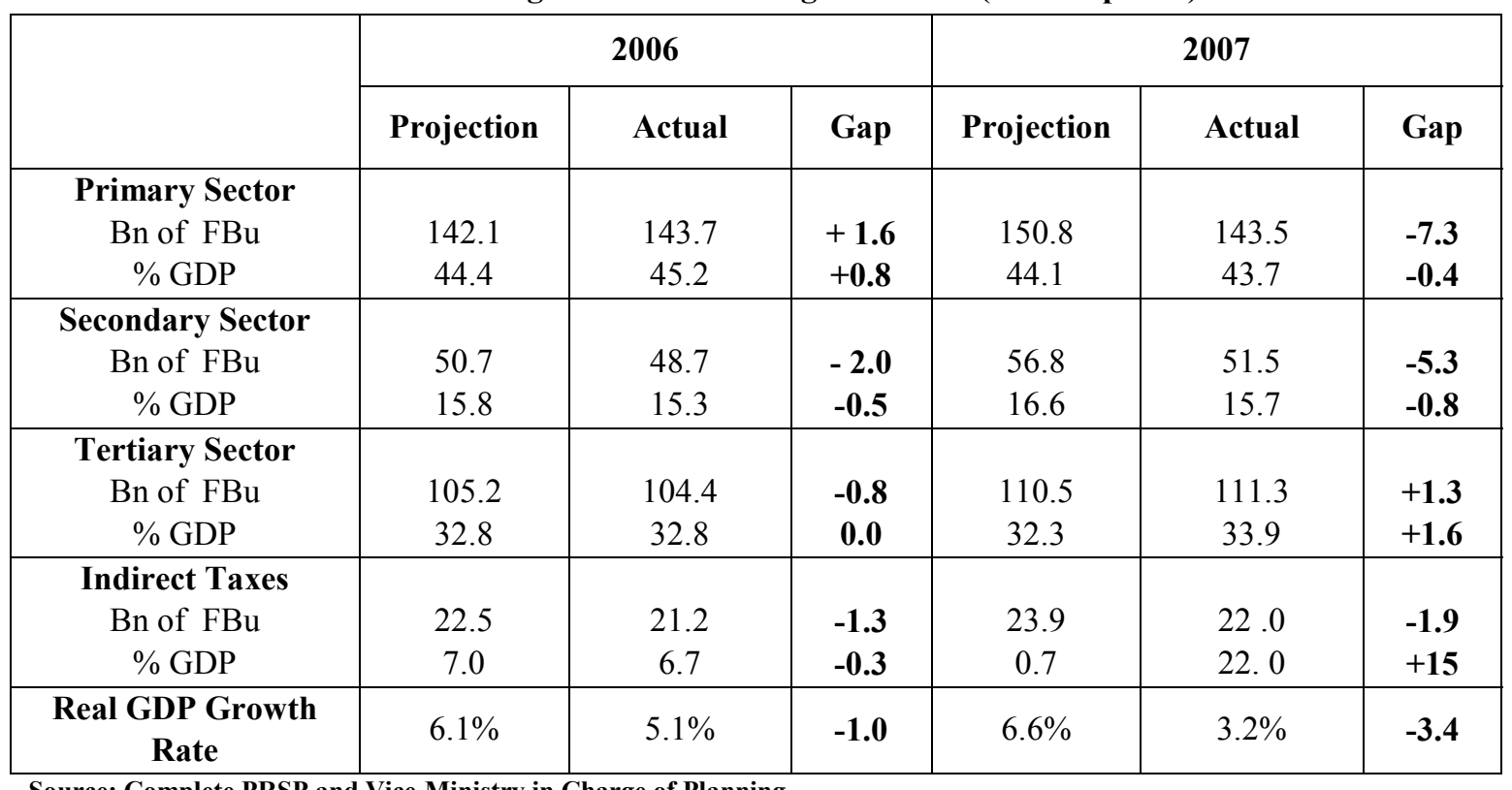

Source: Complete PRSP and Vice-Ministry in Charge of Planning.

308. Beginning in 2007, the beginnings of a transformation of the structure of the economy can be noted. The weight of the primary sector gradually decreased to the benefit of the secondary sector. The tertiary sector, with 33.9 percent of GDP, rose by 1.6 percent over 2006. This increase in the tertiary sector prevented the Burundi economy from having a negative growth rate.

\subsection{Change in inflation}

309. The PRSP set the goal of limiting inflation to 4.8 and 5 percent for 2006 and 2007 respectively. However, as Chart 8 below illustrates, actual inflation rates for 2006 and 2007 were 9.6 percent and 14.4 percent. The general increase in prices in 2007 can be explained by the skyrocketing price of food products due to climate uncertainties, and to the higher price of fuel, up from 1,100 FBu in January 2006 to 1,620 FBu in December 2007. 
Chart 8: Change in inflation.

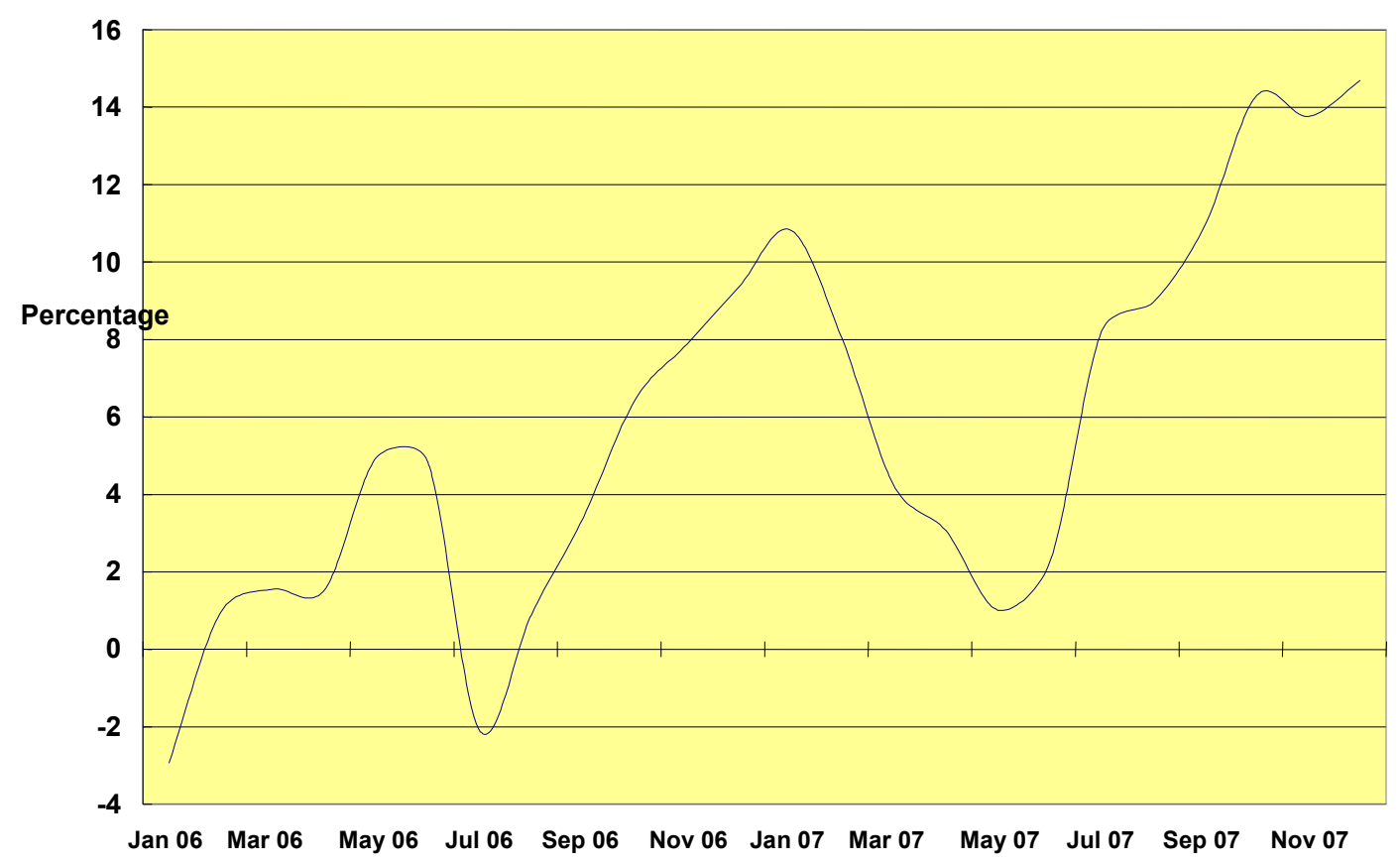

Source: ISTEEBU.

\subsection{External sector}

310. Regarding the trade balance, exports, and in particular imports, easily surpassed PRSP projections in 2006 and in 2007. In 2006 export revenue exceeded projected values by 21.2 billion $\mathrm{FBu}$, while in 2007 , they surpassed them by 5.8 billion. Nevertheless, between the years 2006 and 2007, export revenue was down, from 95.8 billion FBu to 90.6 billion. This fall is largely attributable to the drop in coffee output. The value of imports was 142.1 billion and 86.1 billion FBu more than the 2006 and 2007 forecasts respectively. Between 2006 and 2007, the value of imports rose by 10.6 billion FBu, or an increase of 2.3 percent in value. This increase does not reflect heightened tangible domestic demand, but the higher cost of oil products and the considerable depreciation of the $\mathrm{FBu}$. The consequence is a much greater shortfall in the trade balance than projected in 2006 and in 2007.

Table 21: Trade balance

\begin{tabular}{|l|c|c|c|c|c|c|}
\hline & \multicolumn{3}{|c|}{ 2006 } & \multicolumn{3}{c|}{2007} \\
\hline & Projection & Actual & Gap & Projection & Actual & Gap \\
\hline Trade balance & -243 & -363.9 & $\mathbf{- 1 2 0 . 9}$ & -299.4 & -379.7 & $\mathbf{- 8 0 . 3}$ \\
\hline $\begin{array}{l}\text { Exports (goods and } \\
\text { services) } \\
\text { (Bn of FBu) }\end{array}$ & 74.6 & 95.8 & $+\mathbf{+ 1 . 2}$ & 84.8 & 90.6 & $+\mathbf{5 . 8}$ \\
\hline $\begin{array}{l}\text { Imports } \\
(\text { Bn of FBu) }\end{array}$ & 317.6 & 459.7 & $\mathbf{+ 1 4 2 . 1}$ & 384.2 & 470.3 & $+\mathbf{8 6 . 1}$ \\
\hline
\end{tabular}

Source: BRB 2007 Annual Bulletin 
311. Between 2006 and 2007, the statements of the capital account and financial operations account fell well short of the projections of the PRSP macroeconomic framework. The gaps were on the order of 60 to 140 billion FBu in 2006. This situation is explained by net capital transfers and a net external commitment level (loans and arrears) that were not as high as projected. However, the results of 2006 to 2007 still show positive changes. The capital account rose by 57.9 billion FBu between 2006 and 2007 through debt relief obtained under the HIPC Initiative. Likewise, the financial operations account was down by 4.1 billion FBu, primarily due to amortization abroad.

Table 22 : Capital balance

\begin{tabular}{|l|c|c|c|c|c|c|}
\hline & \multicolumn{3}{|c|}{2006} & \multicolumn{3}{c|}{2007} \\
\hline & Projection & Actual & Gap & Projection & Actual & Gap \\
\hline & & & & & & \\
\hline $\begin{array}{l}\text { Capital account } \\
\text { (billions of FBu) }\end{array}$ & 209.8 & 69.5 & $\mathbf{1 4 0 . 3}$ & 205.7 & 127.4 & $\mathbf{7 8 . 3}$ \\
\hline $\begin{array}{l}\text { Financial operations } \\
\text { account }\end{array}$ & 148.7 & 88.7 & $\mathbf{6 0}$ & 199.4 & 84.6 & $\mathbf{1 1 4 . 8}$ \\
\hline
\end{tabular}

Source: BRB, 2007 Annual Bulletin

\subsection{Monetary survey}

312. The Central Bank strengthened the monetary policy instruments in order to manage the currency conservatively. These instruments are consistent with the growth and macroeconomic stabilization objectives and, to a certain extent, they have contained the stronger inflationary momentum that was shaping up for about the last two years. The Central Bank also made considerable progress in implementing new reforms that affect the management of liquid assets and strengthening the foreign exchange policy. Greater autonomy for the Central Bank should make the results achieved in this area sustainable.

313. The monetary and foreign exchange policy recommended for the short and medium term will be based on the essential goal of containing inflation. The stated goal is to lower the inflation rate to a single figure. The monetary sector's contribution to this will be even more essential since current economic conditions are particularly difficult because of the strong pressure on the price of food staples and oil products.

Change in the main aggregates

314. The change in the monetary survey reflects the results of the conservative policies the Central Bank has been implementing over the last few years. 
Table 23: Change in the principal monetary aggregates

\begin{tabular}{|c|c|c|c|c|c|}
\hline Headings & \multirow{2}{*}{2006} & \multirow{2}{*}{2007} & \multirow{2}{*}{$\begin{array}{c}2007 \\
\text { Projection }\end{array}$} & \multirow{2}{*}{ Gap } & \multirow{2}{*}{ Gap as a $\%$} \\
\hline Monetary survey & & & & & \\
\hline Net foreign assets & 76.0 & 110.9 & 97.8 & 13.1 & 13.4 \\
\hline Central Bank & 42.9 & 77.4 & 54.8 & 22.6 & 41.2 \\
\hline Commercial banks & 33.1 & 33.5 & 43.0 & -9.5 & -22.1 \\
\hline Net domestic assets & 276.2 & 296.8 & 307.1 & -10.3 & -3.4 \\
\hline Domestic credit & 337.4 & 374.0 & 376.8 & -2.8 & -0.7 \\
\hline Credit to the government & 141.2 & 157.4 & 179.4 & -22 & -12.3 \\
\hline Credits to the economy & 196.2 & 216.6 & 197.4 & 19.2 & 9.7 \\
\hline Other items & -61.2 & -77.2 & -69.7 & -7.5 & 10.8 \\
\hline M3 & 352.2 & 407.8 & 404.9 & 2.9 & 0.7 \\
\hline Deposits in foreign currency & 52.3 & 77.7 & 60.2 & 17.5 & 29.1 \\
\hline$M 2$ & 299.9 & 330.1 & 344.7 & -14.6 & -4.2 \\
\hline Currency in circulation & 68.4 & 84.2 & 83.5 & 0.7 & 0.8 \\
\hline Deposits in local currency & 231.5 & 245.9 & 261.2 & -15.3 & -5.9 \\
\hline \multicolumn{6}{|l|}{ Central Bank (near-money deposits) } \\
\hline Net foreign assets & 42.9 & 77.5 & 54.8 & 22.7 & 41.4 \\
\hline Foreign assets & 132.7 & 201.1 & 172.7 & 28.4 & 16.4 \\
\hline Cross-border liabilities & 89.8 & 123.6 & 117.9 & 5.7 & 4.8 \\
\hline Net domestic assets & 63.5 & 47.5 & 65.2 & -17.7 & -27.1 \\
\hline Domestic credit & 137.8 & 138.8 & 132.5 & 6.3 & 4.8 \\
\hline Credit to the government & 144.4 & 134.7 & 162.9 & -28.2 & -17.3 \\
\hline Credits to the economy & -6.6 & 4.1 & -30.5 & 34.6 & -113.4 \\
\hline Other items & -74.3 & -91.3 & -67.3 & -24.0 & 35.7 \\
\hline Base money & 106.4 & 125.0 & 119.9 & 5.1 & 4.3 \\
\hline
\end{tabular}

Source: BRB and projections IMF, Sixth Review of the Agreement under the Poverty Reduction and Growth Facility, p. 17.

315. Net foreign assets increased considerably, 13.4 percent more than projections, between 2006 and 2007. Whereas they were 76 billion in December 2006, they amounted to 110.9 billion in December 2007, for a 45.9 percent increase. This positive change is the result of the improvement in the Central Bank's official reserves, while commercial bank assets were stagnant. As of December 31, 2007, the Central Bank's net foreign assets amounted to 3.6 months of imports, versus four months of imports in December 2006.

316. Domestic credits also rose, from 337.4 billion in December 2006 to 374.9 billion in 2007. During this period, net claims on the government were down slightly (roughly 0.5 percent) due to the measures the government took to gradually lower the use of Central Bank advances to finance the Treasury deficits. By contrast, credits to the economy rose by 10.4 percent, which also shows encouraging progress in terms of implementing policies that contribute to stimulating the private sector.

317. The Central Bank's net domestic assets were down 3.4 percent compared to projections. This is explained by the drop in credit to the government and despite the fact that credit to the economy rose by 9.7 percent. The growth in the money supply (M2) was 10.1 percent in 2007; this reflects an increase slightly greater than the increase in nominal GDP, which was around 8.4 percent. Compared to the 2007 projections, the money 
supply (M2) fell by 4.2 percent; this is explained by the fact that output was down. This change fits in with the Central Bank's objective, which implies that the increase in the money supply should follow the trend in output. By contrast, the M3 money supply rose by 0.7 percent because deposits in foreign currency were up by 17.5 billion.

\section{Change in the exchange rates}

318. The Burundi franc fell in value compared to the major currencies, including the euro (14.9 percent), the pound sterling (14.3 percent) and the US dollar (5 percent). The exchange rate, which was 1,026.07 FBu for one U.S. dollar in December 2006, reached $1,137.91$ one year later. The average annual exchange rates are 1,028.97 and 1,081.93 for 2006 and 2007 respectively. The real nominal average exchange rate was down between these two periods, while the real effective average exchange rate was up slightly.

Chart 9: Change in the real effective exchange rate for the $\mathrm{FBu}(\mathrm{base}=\mathbf{2 0 0 0})$

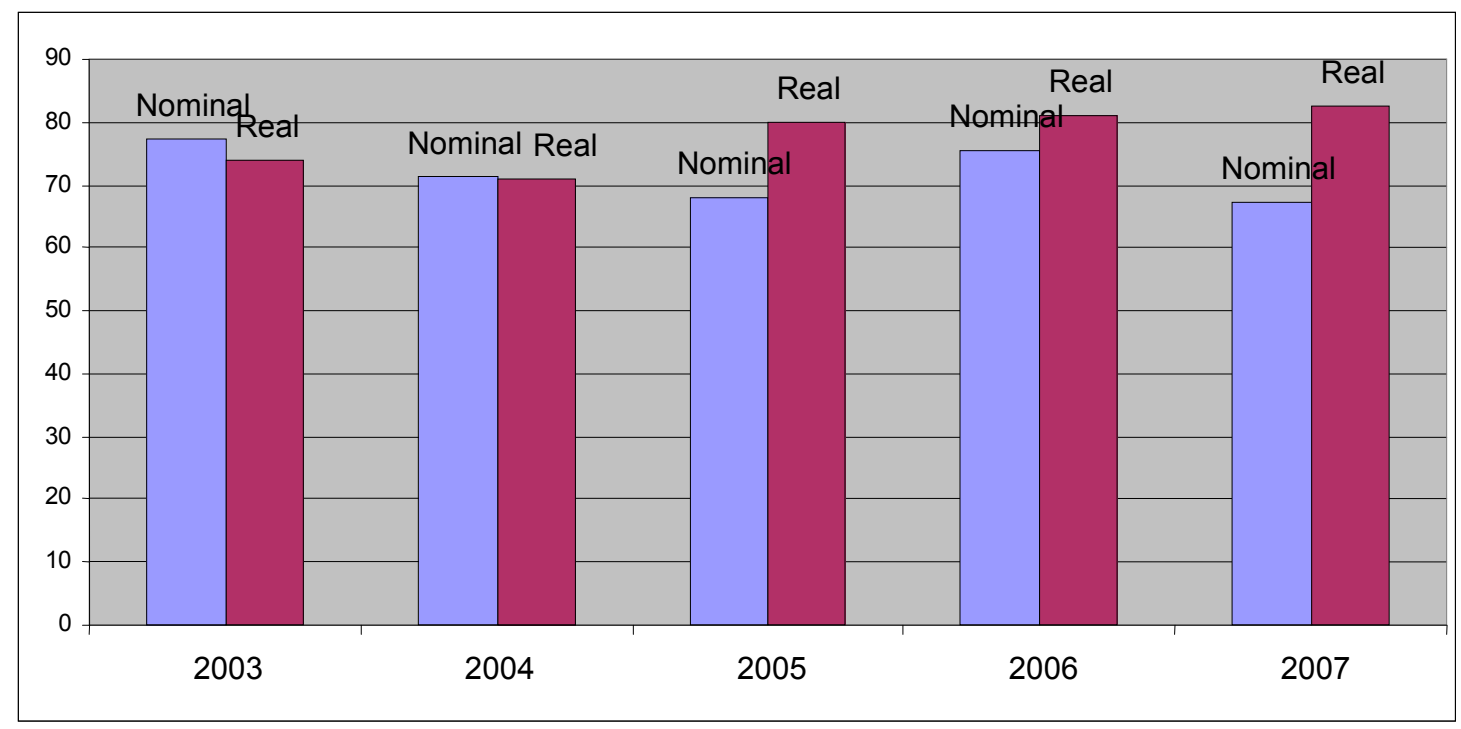

Source: BRB.

6.5 Implementation of the monetary and foreign exchange policy reforms

Auction system for liquidity absorption and/or injection

319. The Central Bank had to deal with several different situations in 2007. The liquidity overhang that prevailed from January to February and from April to mid-August 2007 was replaced by periods of liquidity tensions from February to April and from midAugust to end-October 2007. To adjust to these two situations, the Central Bank had to resort, as applicable, to the auction system for liquidity absorption and/or injection. It should be noted that the Central Bank developed a marginal loan facility for banks with temporary cash shortages; this loan facility provided a positive and complete response to their requirements. 


\section{Development of the Treasury bill and bond market}

320. Beginning in December 2006, the Central Bank established a Treasury bill and bond market to ensure appropriate financing for the government's cash requirements. Thus, the Treasury bill market has grown gradually, with terms that vary from 13 to 16 and 52 weeks. Today, this market is organized on a weekly basis. However, demand remains relatively modest, since it amounted to only 49 percent of the issues, while over 93.9 percent of the transactions are concentrated in short-term bills (13 weeks). It is probably because of this mistrust of the risk that subscriptions for bonds with terms between two and five years are practically nil; only one was recorded for the entire year.

Strengthening the foreign exchange policy

321. The Central Bank played a key role in improving exchange rate management by consolidating transactions in the foreign currency auction market and by streamlining the activities of the exchange houses. This policy curbed the development of the parallel market and reduced the gap between the parallel and official market exchange rate.

\subsection{Budgetary framework}

\section{Link between the PRSP and the budget}

322. The distinction between non-poverty-reducing expenditures and poverty-reducing expenditures is an important PRSP innovation. It enables the technical ministries to allocate budgetary resources that are better suited to the concerns of the poor; it also establishes systematic projections of expenditures during the preparatory phase of the budget, and this explicitly takes sectoral poverty-reducing programs into account.

323. The current determination of poverty-reducing expenditures includes the following factors: (i) the social character inherent in the missions of the different ministries: the option is to systematically include the expenditures in all the ministries classified as "social services;" and (ii) taking into consideration the relevant headings of the Ministries classified as "general services" and "economic services" after a consensual analysis of their social character and how they align with the axes of the PRSP.

324. Budget tracking clarifies the factors to be taken into consideration in terms of current expenditures and capital expenditures. It places special emphasis on the concentration areas in conjunction with HIPC resource allocations. The tracking system is strengthened through the Automated Integrated Financial Management System (SIGEFI), whose design provides an adjusted codification of the budgetary headings starting in fiscal year 2006. Table 24 below shows the principal objectives set by the PRSP in terms of progress expected in poverty-reducing expenditures. 
Table 24: Breakdown of poverty-reducing and non-poverty reducing government expenditures

\begin{tabular}{|l|c|c|c|}
\hline Type of expenditure & $\mathbf{2 0 0 6}$ & $\mathbf{2 0 0 7}$ & $\mathbf{2 0 0 8}$ \\
\hline Ordinary expenditures & $37 \%$ & $34 \%$ & $30 \%$ \\
\hline Non-poverty-reducing & $22 \%$ & $29 \%$ & $29 \%$ \\
\hline Poverty-reducing & $\mathbf{5 9 \%}$ & $\mathbf{6 0 \%}$ & $\mathbf{5 9 \%}$ \\
\hline Subtotal & $1 \%$ & $1 \%$ & $1 \%$ \\
\hline Investment expenditures & $40 \%$ & $39 \%$ & $40 \%$ \\
\hline Non-poverty-reducing & $\mathbf{4 1 \%}$ & $\mathbf{4 0 \%}$ & $\mathbf{4 1 \%}$ \\
\hline Pubtotal & $\mathbf{1 0 0 \%}$ & $\mathbf{1 0 0 \%}$ & $\mathbf{1 0 0 \%}$ \\
\hline \multicolumn{2}{|l|}{} \\
\hline
\end{tabular}

Source: Complete PRSP, September (2006).

325. Budget tracking uses these objectives as a reference and, above and beyond the statement of funds actually disbursed for the poor, it seeks to analyze the reasons for the trends that are observed. This system should be developed gradually, based mainly on the results of the government expenditure tracking and beneficiary satisfaction survey, in order to strengthen the financial flows for the poor and to ensure a better impact.

\section{Revenue and expenditures structure}

326. The budgetary policy the government advocates aims not just to control and rationalize the allocation of government expenditures, but it also aims to make an effort to increase government revenue so that it can absorb the budget deficit that has become chronic. The improvement in performances that has occurred in each of these two objectives uses as a reference the initial projections adopted for the budgetary framework of the PRSP and the quantitative objectives that are included in the context of the PRGF. Generally, the first year of PRSP implementation is characterized by the continued fiscal consolidation through a high level of revenue recovery and conservative expenditure management. The execution level is satisfactory overall.

\section{Domestic revenues}

327. Revenue increased over 2006. This increase can be explained by several decisions related to tax policy. First, another increase in taxes on oil products can be mentioned; this tax was lowered in 2006. Next, there is the increase in the tax on goods and services, with an annual decrease of 6.9 percent; finally, the income tax was raised, and this brought about a 19.0 percent growth rate. Moreover, significant progress was made in non-tax revenues, which amounted to 15 billion $\mathrm{FBu}$ as opposed to the projected 12.1 billion. Total revenue levels were about 5 billion over the projections in the PRGF program.

Table 25: Projected and actual revenues

\begin{tabular}{|l|c|c|c|c|}
\hline Year & PRSP Projection & PRGF Projection & Actual & Tax pressure (\% of GDP) \\
\hline 2006 & 181.60 & - & 178.8 & $18.9 \%$ \\
\hline 2007 & 210.20 & 192.9 & 197.6 & $18.7 \%$ \\
\hline
\end{tabular}

Sources: Complete PRSP, p. 70, for the PRSP and MEFCD projections. 


\section{Net expenditures and loans}

\section{(1) General trends}

328. Budgetary expenditures remained high, up from 361 billion in 2006 to 408.3 billion in 2007, for a 13 percent increase. In this period, net expenditures and loans amounted to 38.2 percent and 38.5 percent of GDP respectively. Demobilization expenditures were well below projections (12.2 billion versus 33 billion $\mathrm{FBu}$ ), and lowered the amount of total expenditures compared to the amount the PRGF projected. Other than expenditures for demobilization and projects, the other budget line items rose to finance the government's social policy, particularly in the area of education and health.

Table 26: Change in government expenditures (billions of FBu).

\begin{tabular}{|c|c|c|c|c|}
\hline \multirow{2}{*}{ Heading } & \multirow{2}{*}{$\begin{array}{c}2006 \\
\text { Actual (1) }\end{array}$} & \multicolumn{2}{|c|}{2007} & \multirow[b]{2}{*}{ Gap (3-2) } \\
\hline & & PRGF (2) & Actual (3) & \\
\hline Net expenditures and loans & 361.0 & 421.3 & 408.3 & -13.0 \\
\hline Current expenditures & 221.5 & 253.0 & 261.2 & 8.2 \\
\hline Salaries & 93.9 & 112.2 & 114.0 & 1.8 \\
\hline Goods and services & 63.8 & 66.8 & 70.7 & 3.9 \\
\hline Transfers and grants & 39.5 & 44 & 46.7 & 2.7 \\
\hline Interest owed & 24.3 & 30 & 29.9 & -0.1 \\
\hline Demobilization & 23.5 & 33 & 12.2 & -20.8 \\
\hline Project expenditures & 116.8 & 137.3 & 134.8 & -2.5 \\
\hline
\end{tabular}

Source: MEFCD.

\section{Current expenditures}

329. Compared to 2006, current expenditures ticked up due to the concomitant impulse of wages and the acquisition of goods and services. In 2007, remuneration amounted to 114.0 billion $\mathrm{FBu}$, which was a substantial increase of 21.4 percent compared to the 2006 level. Expenditures for goods and services were also up about 10.8 percent in the same period.

Special investment budget expenditures

330. Capital goods expenditures rose from 116.8 billion $\mathrm{FBu}$ in 2006 to 134.8 billion $\mathrm{FBu}$ in 2007, for a 15.4 percent growth rate. The amount of 81.5 billion FBu was financed in investment expenditures using external resources and 35.3 billion using domestic resources in 2006. These amounts were 105.9 billion $\mathrm{FBu}$ and 28.9 billion $\mathrm{FBu}$ respectively in 2007. It is important to note an upward trend in investment expenditures using external resources (29.9 percent) and a drop in investments using domestic resources estimated at 18.0 percent. Moreover, the low special investment budget execution level is the consequence of the persistent weakness in the ability to design and implement development projects. This was already mentioned and discussed when the PRSP was being prepared and thus merits very special attention, especially in the technical departments. The managers of these departments should acquire a good mastery of project management so that this deficiency does not interfere greatly with the successful implementation of the PRSP. 


\section{Financing requirements}

331. The deficit on a commitment basis (excluding grants) is 210.4 billion FBu in 2007 $\mathrm{FBu}$ versus 182.2 billion in the previous year. This is explained by a larger increase in expenditures than revenue. The persistent deficit observed from one year to the next could be absorbed only through foreign support, as shown in the figures in below. The gap of FBu 17.9 billion between the actual figures and projections is primarily due to the decrease in expenditures for demobilization and projects.

Table 27: Financing of the budget deficits (billions of FBu)

\begin{tabular}{|c|c|c|c|c|}
\hline \multirow{2}{*}{ Heading } & \multirow{2}{*}{$\begin{array}{c}2006 \\
\text { Actual (1) }\end{array}$} & \multicolumn{3}{|c|}{2007} \\
\hline & & PRGF (2) & Actual (3) & Gap (3-2) \\
\hline Balance on a commitment basis & -182.2 & -228.4 & -210.5 & 17.9 \\
\hline After grants & -17.1 & 22.4 & 10.8 & -11.6 \\
\hline Primary balance & -53.7 & -61.5 & -62.5 & -1.0 \\
\hline Financing & 199.7 & 263.6 & 232.3 & -31.3 \\
\hline Foreign grants & 168.9 & 250.8 & 221.4 & -29.4 \\
\hline Budget grants & 67.5 & 96.0 & 87.4 & -8.6 \\
\hline HIPC & 36.7 & 40.7 & 40.0 & 0.0 \\
\hline MDRI & 0.0 & 0.0 & 0.0 & 0.0 \\
\hline Project grants & 41.2 & 81.1 & 81.1 & 0.0 \\
\hline Special programs & 23.5 & 33.0 & 12.2 & -20.8 \\
\hline Foreign loans & 6.4 & -8.8 & -9.3 & -0.5 \\
\hline Domestic debt & 21.3 & 21.6 & 20.1 & -1.5 \\
\hline Banking sector & 20.1 & 7.8 & 16.2 & 8.4 \\
\hline Nonbanking sector & 1.2 & 13.8 & 3.9 & -9.9 \\
\hline Product of privatization & 3.1 & & 0.1 & 0.1 \\
\hline Errors and omissions & -3.8 & $\mathbf{0 . 0}$ & -0.1 & -0.1 \\
\hline
\end{tabular}

Source: MEFCD.

332. External resources increased overall during the period under consideration and consisted mainly of grants. The deficit including grants was down considerably in 2006 and became positive in 2007. However, the anticipated resources could not be fully mobilized since the funds that were disbursed are 31.3 billion FBu less than projected. It is also important to note the drop in debt to the banking sector, the amount of which fell from 20.1 billion FBu in 2006 to 16.2 billion in 2007.

333. A specific coding system for expenses to fight poverty was introduced into the data processing system. It uses a special marking, in other words, a special code in the expenditures grid identifies the poverty-reducing expenditures.

Table 28: 2006 revised budgetary expenditures (millions of FBu).

\begin{tabular}{|l|l|c|c|c|c|c|c|}
\hline & Description & $\begin{array}{c}\text { Poverty- } \\
\text { reducing } \\
\text { expenditures }\end{array}$ & $\%$ & $\begin{array}{c}\text { Nonpoverty- } \\
\text { reducing } \\
\text { expenditures }\end{array}$ & $\%$ & $\begin{array}{c}\text { Total } \\
\text { expenditures }\end{array}$ & $\%$ \\
\hline 01 & General services & $32,345.7$ & 6.87 & $144,204.5$ & 30.65 & $176,550.2$ & 37.52 \\
\hline 02 & Defense & $24,583.9$ & 5.23 & $48,274.2$ & 10.26 & $72,858.1$ & 15.49 \\
\hline 03 & Public security & $3,047.1$ & 0.65 & $29,392.5$ & 6.25 & $32,439.7$ & 6.89 \\
\hline 04 & Economic affairs & $56,602.2$ & 23.04 & $1,158.4$ & 0.25 & $57,760.6$ & 12.28 \\
\hline
\end{tabular}




\begin{tabular}{|l|l|c|c|c|c|c|c|}
\hline 05 & Environment & 304.2 & & 223.1 & 0.05 & 527.2 & 0.11 \\
\hline 06 & $\begin{array}{l}\text { Housing and } \\
\text { collective capital } \\
\text { goods }\end{array}$ & $1,912.2$ & 0.41 & 149.2 & 0.03 & $2,061.5$ & 0.44 \\
\hline 07 & Health & $22,599.2$ & 4.80 & 14.0 & 0.00 & $22,613.2$ & 4.81 \\
\hline 08 & $\begin{array}{l}\text { Leisure, culture and } \\
\text { worship }\end{array}$ & 879.1 & 0.19 & 68.7 & 0.01 & 947.8 & 0.20 \\
\hline 09 & Education & $37,573.8$ & 7.99 & 735.2 & 0.33 & $38,309.0$ & 8.14 \\
\hline 10 & Social protection & $1,650.0$ & 0.35 & 634.4 & 0.13 & $2,284.4$ & 0.49 \\
\hline & Total & $\mathbf{2 4 5 , 6 3 4 . 9}$ & $\mathbf{5 2 . 2 1}$ & $\mathbf{2 2 4 , 8 5 4 . 2}$ & $\mathbf{4 7 . 7 9}$ & $\mathbf{4 7 , 0 4 8 9 . 1}$ & $\mathbf{1 0 0 . 0 0}$ \\
\hline
\end{tabular}

Source: MEFCD, 2006 Finance Law

334. First it should be noted that the 2006 budgetary projections reflect a considerable increase in the share of poverty-reducing expenditures; rising to 52.21 percent versus 43.2 percent in the previous year. The 2007 Finance Law also confirms this commitment from the government; in the 2007 budget, the share of expenditures to reduce poverty was 57.0 percent.

Table 29: 2007 enacted budgetary expenditures

\begin{tabular}{|l|l|c|c|c|c|c|c|}
\hline Code & Description & $\begin{array}{c}\text { Poverty- } \\
\text { reducing } \\
\text { expenditures }\end{array}$ & $\%$ & $\begin{array}{c}\text { Nonpoverty- } \\
\text { reducing } \\
\text { expenditures }\end{array}$ & $\%$ & $\begin{array}{c}\text { Total } \\
\text { expenditures }\end{array}$ & \% \\
\hline 01 & General services & $47,147.8$ & 9.7 & $118,647.4$ & 24.4 & $165,795.2$ & 34.1 \\
\hline 02 & Defense & $40,385.1$ & 8.3 & $52,779.2$ & 10.9 & $93,164.2$ & 19.2 \\
\hline 03 & Public security & $8,757.3$ & 1.8 & $33,854.7$ & 7.0 & $42,612.0$ & 8.8 \\
\hline 04 & $\begin{array}{l}\text { Economic } \\
\text { affairs }\end{array}$ & $73,140.4$ & 15.1 & $1,332.4$ & 0.3 & $74,472.8$ & 15.3 \\
\hline 05 & Environment & 411.4 & 0.1 & 251.0 & 0.1 & 662.5 & 0.1 \\
\hline 06 & $\begin{array}{l}\text { Housing and } \\
\text { collective } \\
\text { capital goods }\end{array}$ & $5,323.2$ & 1.1 & 151.5 & 0.0 & $5,474.7$ & 1.1 \\
\hline 07 & Health & $18,163.1$ & 3.7 & 60.0 & 0.0 & $18,223.2$ & 3.8 \\
\hline 08 & $\begin{array}{l}\text { Leisure, culture } \\
\text { and worship }\end{array}$ & $1,227.4$ & 0.3 & 29.7 & 0.0 & $1,257.1$ & 0.3 \\
\hline 09 & Education & $80,094.2$ & 16.5 & 802.6 & 0.2 & $80,869.8$ & 16.7 \\
\hline 10 & $\begin{array}{l}\text { Social } \\
\text { protection }\end{array}$ & $2,424.6$ & 0.5 & 733.4 & 0.2 & $3,158.0$ & 0.7 \\
\hline & Total & $\mathbf{2 7 7 , 0 7 4 . 5}$ & $\mathbf{5 7 . 0}$ & $\mathbf{2 0 , 8 6 4 2 . 0}$ & $\mathbf{4 3 . 0}$ & $\mathbf{4 8 5 , 7 1 6 . 5}$ & $\mathbf{1 0 0 . 0}$ \\
\hline
\end{tabular}

Source: MEFCD, 2007 Finance Law

Budget execution and actual poverty-reducing expenditures

Budget execution and actual poverty-reducing expenditures

335. Resources seem to have been effectively allocated to the poverty-reducing programs as recommended in the PRSP. However, the budget execution rate planned for 2006 (78.2 percent) needs to be explained by the non-disbursement of funds provided under budgetary support. This difficult situation forced the government to lower povertyreducing expenditures to make the priority expenditures required for wages for civil servants and security. Thus, the allocation of 47.1 percent of scarce resources to povertyreducing programs can be considered a major effort. 
Table 30: Execution of budgetary expenditures, year 2006

\begin{tabular}{|l|l|c|c|c|c|c|c|}
\hline Code & Description & $\begin{array}{c}\text { Poverty- } \\
\text { reducing } \\
\text { expenditures }\end{array}$ & $\%$ & $\begin{array}{c}\text { Nonpoverty- } \\
\text { reducing } \\
\text { expenditures }\end{array}$ & $\%$ & $\begin{array}{c}\text { Total } \\
\text { expenditures }\end{array}$ & \% \\
\hline 01 & General services & 6.8 & 1.8 & 117.9 & 32.0 & 124.7 & 33.9 \\
\hline 02 & Defense & 24.3 & 6.6 & 47.5 & 12.9 & 71.8 & 19.5 \\
\hline 03 & Public security & 6.1 & 1.7 & 26.7 & 7.3 & 32.8 & 8.9 \\
\hline 04 & Economic affairs & 44.2 & 12.0 & 1.0 & 0.3 & 45.2 & 12.3 \\
\hline 042 & Environment & 23.4 & 6.4 & 0.0 & 0.0 & 23.4 & 6.4 \\
\hline 05 & $\begin{array}{l}\text { Housing and } \\
\text { gollective capital }\end{array}$ & 0.3 & 0.1 & 0.2 & 0.1 & 0.5 & 0.1 \\
\hline 06 & Health & 3.2 & 0.9 & 0.0 & 0.0 & 3.2 & 0.9 \\
\hline 07 & $\begin{array}{l}\text { Leisure, culture and } \\
\text { worship }\end{array}$ & 19.9 & 5.4 & 0.0 & 0.0 & 19.9 & 5.4 \\
\hline 08 & Education & 0.9 & 0.2 & 0.1 & 0.0 & 1.0 & 0.3 \\
\hline 09 & Social protection & 64.7 & 17.6 & 0.5 & 0.1 & 65.2 & 17.7 \\
\hline 10 & General services & 3.0 & 0.8 & 0.8 & 0.2 & 3.8 & 1.0 \\
\hline & Total & $\mathbf{1 7 3 . 4}$ & $\mathbf{4 7 . 1}$ & $\mathbf{1 9 4 . 6}$ & $\mathbf{5 2 . 9}$ & $\mathbf{3 6 8 . 0}$ & $\mathbf{1 0 0 . 0}$ \\
\hline
\end{tabular}

Source: MEFCD, Monthly commitment-based expenditure reports.

336. During fiscal year 2007, poverty-reducing expenditures accounted for over 52 percent of total spending. This positive trend is the result of better control over security that prevailed during this period. In conclusion, it is important to underscore that, despite the budgetary difficulties due to the low mobilization of official development assistance, the government's commitment to work for the poor is clear in budget execution. 
Table 31: Execution of budget expenditures in 2007

\begin{tabular}{|c|l|c|c|c|c|c|c|}
\hline Code & Description & $\begin{array}{c}\text { Poverty- } \\
\text { reducing } \\
\text { expenditures }\end{array}$ & $\%$ & $\begin{array}{c}\text { Nonpoverty- } \\
\text { reducing } \\
\text { expenditures }\end{array}$ & $\%$ & $\begin{array}{c}\text { Total } \\
\text { expenditures }\end{array}$ & \% \\
\hline 01 & General services & 44.4 & 10.3 & 118.7 & 27.4 & 163.1 & 37.7 \\
\hline 02 & Defense & 11.5 & 2.7 & 52.2 & 12.1 & 63.7 & 14.7 \\
\hline 03 & Public security & 8.7 & 2.0 & 32.2 & 7.4 & 41.0 & 9.5 \\
\hline 04 & Economic affairs & 54.7 & 12.7 & 1.1 & 0.3 & 55.9 & 12.9 \\
\hline 042 & Environment & 19.8 & 4.6 & 0.0 & 0.0 & 19.8 & 4.6 \\
\hline 05 & $\begin{array}{l}\text { cousing and collective } \\
\text { capital goods }\end{array}$ & 0.4 & 0.1 & 0.0 & 0.0 & 0.4 & 0.1 \\
\hline 06 & Health & 6.8 & 1.6 & 0.0 & 0.0 & 6.8 & 1.6 \\
\hline 07 & $\begin{array}{l}\text { Leisure, culture and } \\
\text { worship }\end{array}$ & 23.8 & 5.5 & 0.0 & 0.0 & 23.8 & 5.5 \\
\hline 08 & Education & 1.2 & 0.3 & 0.0 & 0.0 & 1.3 & 0.3 \\
\hline 09 & Social protection & 73.5 & 17.0 & 0.4 & 0.1 & 74.0 & 17.1 \\
\hline 10 & General services & 1.9 & 0.5 & 0.9 & 0.2 & 2.9 & 0.7 \\
\hline & Total & $\mathbf{2 2 7 . 0}$ & $\mathbf{5 2 . 5}$ & $\mathbf{2 0 5 . 7}$ & $\mathbf{4 7 . 5}$ & $\mathbf{4 3 2 . 7}$ & $\mathbf{1 0 0 . 0}$ \\
\hline
\end{tabular}

Source: MEFCD, Monthly commitment-based expenditure reports

Targeting the poor in government expenditures

Government expenditures for health

337. The policy of free care for young children and free delivery for mothers had a significant impact on the budget beginning in 2006. Spending on medical products, devices and equipment, a category that this policy affects directly, thus amounted to 10.7 billion $\mathrm{FBu}$, or more than half (54 percent) of the budget allocated to the Ministry of Public Health and HIV/AIDS Control. Public health services are second at 5.8 billion. A smaller amount is allocated to hospital services (2.4 billion or 12 percent). Investments were also necessary to improve accommodation capacities. Of a total budget of 19.9 billion, 10.7 billion were spent on improving these capacities.

Table 32: Breakdown of poverty-reducing expenditures in the health sector (billions of FBu).

\begin{tabular}{|l|l|c|c|}
\hline Code & Category & $\mathbf{2 0 0 6}$ & $\mathbf{2 0 0 7}$ \\
\hline 07 & Health & 19.9 & 23.8 \\
\hline 071 & Medical products, devices and equipment & 10.7 & 8.5 \\
\hline 072 & Outpatient services & 0.8 & 0.5 \\
\hline 073 & Hospital services & 2.4 & 7.7 \\
\hline 0740 & Public health services & 5.8 & 7.0 \\
\hline 0750 & R\&D in the area of health & 0.0 & 0.0 \\
\hline 0760 & Health, n.i.e. & 0.2 & 0.1 \\
\hline
\end{tabular}

Source: MEFCD, Monthly expenditure reports based on commitment.

338. The allocations are divided differently in 2007. About 8.5 billion $\mathrm{FBu}$, or 36 percent of the budget, was spent on medical products, devices and equipment. Hospital 
serves are in second place with 7.7 billion or 32 percent of total spending. The amount of spending on public health services increased in absolute value from 5.8 billion in 2006 to 7.0 billion in 2007, but not in relative value. Outpatient services became slightly less important as its budget was down from 0.8 billion to 0.5 billion, and its share of the budget in the health sector for reducing poverty is 2 percent versus 4 percent the previous year. Finally, investment expenditures were down from 10.7 to 10.2 billion $\mathrm{FBu}$.

Spending on education

339. The majority (54 percent) of the 2006 education budget was spent on preelementary and primary education, which alone accounted for 35 billion FBu. It was followed by secondary education, which received 15.1 billion $\mathrm{FBu}$, or 23 percent. About 11.4 billion $\mathrm{FBu}$, or 17 percent, was allocated to auxiliary services, while budget usage in the other categories of education did not exceed 3 percent. These factors show that very special attention was paid to free primary education when the execution of the 2006 budget began. By contrast, of a total budget of 65.2 billion, only 8.1 billion is spent on investment, while major programs for building new classrooms were necessary.

Table 33: Poverty-reducing expenditures in the education sector (billions of FBu).

\begin{tabular}{|l|c|c|}
\hline Category & Year 2006 & Year 2007 \\
\hline Education & 65.2 & 74.0 \\
\hline Preliminary and primary education & 35.0 & 39.9 \\
\hline Secondary education & 15.1 & 17.2 \\
\hline Post-secondary non-higher education & 0.0 & 0.0 \\
\hline Higher education & 2.0 & 2.0 \\
\hline Education not defined by level & 1.2 & 1.2 \\
\hline Services related to education & 11.4 & 13.4 \\
\hline Education R\&D & 0.0 & 0.0 \\
\hline Education, n.i.e. & 0.3 & 0.3 \\
\hline
\end{tabular}

Source: MEFCD, Monthly expenditure reports based on commitment

340. The share of the budget used for spending on pre-elementary and primary education was unchanged in 2007, at 39.9 billion FBu. Secondary education is in second place with 17.2 billion. Education services again are considerable, at 13.4 billion $\mathrm{FBu}$, which accounts for 17 percent of the poverty-reducing budget for the education sector. Efforts were concentrated at first on providing educational materials and hiring new teaching staff to cope with the unprecedented flows of new schoolchildren. Finally, of a total budget of 74 billion, just 10 billion was spent on investments in school infrastructure; this amounts to just 14 percent. Investment does not seem to have kept pace with requirements, largely because of the lengthy delays in starting construction work on new schools.

\section{Concentration areas for HIPC expenditures}

341. The debt relief obtained when Burundi accessed the decision point increased the resources to be allocated to the poor. In 2006, 52.5 percent of HIPC spending was directed to education. The health sector received 15.6 percent of the commitments, with priority on hospitalization services, outpatient services and public health services. HIPC 
expenditures also amount to 10.7 percent of social protection. There is an urgent need to strengthen the capacities of the different services that use HIPC resources to bridge the gap between projections and actual figures. This includes in particular capacities to harness procedures and to design and implement the priority projects to be carried out. Improving absorption rates is thus a major challenge for the very near term.

Table 34: Execution of HIPC expenditures

\begin{tabular}{|c|c|c|c|c|c|}
\hline \multirow{2}{*}{ Code } & \multirow{2}{*}{ Category } & \multicolumn{2}{|c|}{ Year 2006} & \multicolumn{2}{|c|}{ Year 2007} \\
\hline & & Amount & $\%$ & Amount & $\%$ \\
\hline 01 & General services of government agencies & 0.3 & 2.1 & 1.7 & 6.5 \\
\hline 013 & General services & 0.3 & 2.1 & 1.7 & 6.5 \\
\hline 02 & Defense & 0.0 & 0.0 & $\mathbf{0 . 0}$ & $\mathbf{0 . 0}$ \\
\hline $\mathbf{0 3}$ & Public order and security & 0.2 & 1.4 & $\mathbf{0 . 0}$ & $\mathbf{0 . 0}$ \\
\hline 0340 & Prison administration & 0.2 & 1.4 & 0.0 & 0.0 \\
\hline 04 & Economic affairs & 2.5 & $\mathbf{1 7 . 2}$ & 4.5 & $\mathbf{1 7 . 5}$ \\
\hline 042 & Agriculture, forestry, fishing and hunting & 0.0 & 0.3 & 0.1 & 0.3 \\
\hline 0421 & Agriculture & 0.0 & 0.3 & 0.1 & 0.3 \\
\hline 043 & Fuels and energy & 0.8 & 5.5 & 1.1 & 4.2 \\
\hline 0431 & Coal and other solid mineral fuels & 0.4 & 2.5 & 0.1 & 0.3 \\
\hline 0436 & Nonelectrical energy & 0.4 & 3.0 & 0.7 & 2.8 \\
\hline 045 & Transport & 1.6 & 11.0 & 1.0 & 3.9 \\
\hline 0451 & Road transport & 1.6 & 11.0 & 1.0 & 3.9 \\
\hline 048 & R\&D for economic affairs & 0.1 & 0.4 & 2.3 & 9.1 \\
\hline 0482 & R\&D for agriculture, forestry, fishing and hunting & 0.1 & 0.4 & 2.3 & 9.1 \\
\hline 06 & Housing and social infrastructure & 0.1 & 0.5 & 0.1 & 0.4 \\
\hline 0630 & Water supply & 0.1 & 0.5 & 0.0 & 0.0 \\
\hline 07 & Health & 2.2 & 15.6 & 8.5 & 33.3 \\
\hline 071 & Medical products, devices and equipment & 0.1 & 0.6 & 1.1 & 4.5 \\
\hline 072 & Outpatient services & 0.8 & 5.8 & 0.5 & 1.8 \\
\hline 0721 & General medicine services & 0.5 & 3.8 & 0.4 & 1.5 \\
\hline 0722 & Specialized medicine services & 0.3 & 2.0 & 0.1 & 0.4 \\
\hline 073 & Hospital services & 0.5 & 3.8 & 5.6 & 22.0 \\
\hline 0740 & Public health services & 0.6 & 4.4 & 1.2 & 4.6 \\
\hline 0760 & Health, n.i.e. & 0.2 & 1.1 & 0.1 & 0.5 \\
\hline 08 & Leisure, culture and worship & $\mathbf{0 . 0}$ & $\mathbf{0 . 0}$ & $\mathbf{0 . 0}$ & $\mathbf{0 . 0}$ \\
\hline 09 & Education & 7.6 & 52.5 & 9.7 & 38.1 \\
\hline 091 & Pre-elementary and primary education & 7.4 & 51.4 & 9.4 & 37.0 \\
\hline 0912 & Primary education & 7.4 & 51.4 & 9.4 & 37.0 \\
\hline 092 & Secondary education & 0.2 & 1.0 & 0.3 & 1.1 \\
\hline 0921 & General secondary education & 0.1 & 0.5 & 0.0 & 0.0 \\
\hline 0922 & Technical secondary education & 0.1 & 0.6 & 0.3 & 1.1 \\
\hline 10 & Social protection & 1.5 & 10.7 & 1.1 & 4.2 \\
\hline 101 & Disease, disability and old-age & 0.0 & 0.1 & 0.0 & 0.0 \\
\hline 1011 & Disease & 0.0 & 0.1 & 0.0 & 0.0 \\
\hline 1040 & Family and children & 1.4 & 9.8 & 0.5 & 2.0 \\
\hline 1070 & Social exclusion, n.i.e. & 0.1 & 0.7 & 0.0 & 0.0 \\
\hline 1090 & Social protection, n.i.e. & 0.0 & 0.1 & 0.6 & 2.2 \\
\hline & Total & 14.4 & 100.0 & 25.5 & 100.0 \\
\hline
\end{tabular}

Source: Based on MEFCD data on a commitment basis 
342. For the year 2007, the profile of how HIPC expenditures are distributed changed. To be sure, education still ranks first, but the percentage of its allocated HIPC spending fell to 38.1 percent and seems to be slightly more confined to primary education (37.0 percent). Health ranks second, with 33.3 percent of spending, used primarily for hospital services. Moreover, it should be noted that a portion (9.1 percent) is used for agricultural research. The allocation for transport was down and amounts to just 3.9 percent of HIPC expenditures. These percentages, however, have not lowered the amounts allocated since HIPC funding is higher in 2007 than in 2006.

343. Generally, HIPC expenditures were in investments. In 2006, of a total available budget of 14.4 billion, just 4 billion, or 28 percent, is considered operating expenditures. Investment expenditures amount to 10.4 billion (72 percent). In 2007, the share of investment in HIPC expenditures fell to 68 percent. However, these investments amount to 17.4 billion $\mathrm{FBu}, 15.6$ billion of which went to fixed assets.

Box 1: HIPC

All HIPC resources are from the debt relief obtained when Burundi reached the decision point in 2005. Burundi expects to reach the completion point around late 2008. To this end, the government is in the process of implementing the conditions agreed upon with the partners:

(i) PRSP: The complete PRSP was drawn up using a participatory process and the strategy was implemented satisfactorily for at least one year, confirmed by the annual progress report analyzed in a joint consultative memorandum by IMF and IDA staff.

(ii) Macroeconomic stability: Macroeconomic stability shown by the satisfactory implementation of the program supported by the PRGF.

(iii) Use of budget savings brought about by debt relief under the HIPC Initiative HIPC during the interim period: Use of budget savings in compliance with the priorities identified at the decision point and in the PRSP, duly described and analyzed every six months by a national independent surveillance committee.

(iv) Fiscal management: Put in place an integrated computerized system for spending to reduce poverty and to prepare at least two quarterly reports on budget execution using the new unified budget classification system.

(v) Measures related to governance and the provision of services in the key sectors: For the education, health and justice sectors, (i) track government expenditures (budget tracking) incurred to provide services for the poor; (ii) have users evaluate the quality of these services; (iii) have the suppliers evaluate the barriers to effectively providing these same services; and (iv) prepare an action plan to solve the problems that were found.

(vi) Demobilization: Carry out the national disarmament, demobilization and reintegration program according to the schedule and the final objectives expressed in the demobilization policy letter to the World Bank, dated February 19, 2004.

(vii) Structural measures: Launch invitations to bid for selling the government's stake in most of the coffee washing facilities. This trigger has been reformulated to adopt an action plan that will be determined in the study on the government strategy for disengagement from the coffee industry.

(viii) Social sectors:

(a) Education: Raise the gross national enrollment rate from 74 percent in 2003/2004 to 77 percent in 2006/2007 for the primary level, and from 16 to 18 percent for the secondary level. The average increase in the provinces that had an enrollment rate below the average in 2004 should however be higher than the increase in the national rate during the same period;

(b) Health: Increase the national immunization rate for children less than one year old from 75 percent in 2004 to 85 percent in 2006. The average increase in the provinces that had an immunization rate below the average in 2004 should, however, be higher than the increase in the national rate during the same period.

(ix) Debt management: Produce external monthly reports on the debt that include projections for the next three months and for at least the six months before the completion point. 


\subsection{Macroeconomic projections}

344. By analyzing the macroeconomic results recorded during these last years, assumptions can be made about the trends expected over the next three years. According to the IMF report, the projected growth structure, which looks like the structure observed in other countries coming out of conflict, is based on three factors: (i) continuing the elimination of the principal economic distortions, in particular in the coffee sector, which will stimulate total productivity of the factors; (ii) a substantial increase in investment, driven by international assistance, and consisting principally of renovating infrastructure, which will help ease the main bottlenecks; and (iii) new progress in liberalizing trade with membership in the CAE, which will contribute to diversifying the economy, stimulating competition, and attracting more investments. The projections for the main aspects are shown in Table 35 below.

Table 35: 2008-2011 economic projections.

\begin{tabular}{|c|c|c|c|c|c|}
\hline Heading & $\mathbf{2 0 0 7}$ & $\mathbf{2 0 0 8}$ & $\mathbf{2 0 0 9}$ & $\mathbf{2 0 1 0}$ & $\mathbf{2 0 1 1}$ \\
\hline Real growth (\%) & 3.6 & 4.5 & 5.0 & 5.0 & 5.0 \\
\hline Inflation (\%) & 8.3 & 19.1 & 9.4 & 8.2 & 6.8 \\
\hline $\begin{array}{c}\text { Exports } \\
\text { (millions of US\$) } \\
\text { (\% GDP) }\end{array}$ & 50.2 & 69.6 & 68.3 & 75.3 & 78.1 \\
\cline { 2 - 6 } $\begin{array}{c}\text { Imports } \\
\text { (millions of US\$) } \\
\text { (\% GDP) }\end{array}$ & 5.2 & 6.1 & 5.0 & 5.0 & 4.8 \\
\cline { 2 - 6 } & 256.4 & 346.7 & 363.4 & 409.3 & 371.6 \\
\hline $\begin{array}{c}\text { Trade balance (millions of } \\
\text { US\$) }\end{array}$ & -206.1 & -277.1 & -295.2 & -333.9 & -293.5 \\
\cline { 2 - 6 } (\% GDP) & -21.2 & -24.3 & -21.8 & -22.1 & -18.2 \\
\hline $\begin{array}{c}\text { Current account (excluding } \\
\text { official transfers) }\end{array}$ & -328.5 & -394.3 & -446.9 & -478.8 & -451.7 \\
\hline $\begin{array}{c}\text { Capital account (millions of } \\
\text { US\$) }\end{array}$ & 127.4 & 145.0 & 1196.5 & 143.3 & 150.3 \\
\hline $\begin{array}{c}\text { Financial account (millions } \\
\text { of US\$) }\end{array}$ & 84.6 & 79.4 & -948.0 & 99.1 & 87.8 \\
\hline $\begin{array}{c}\text { Government revenues } \\
\text { (billions of FBu) }\end{array}$ & 197.6 & 249.8 & 288.6 & 330.3 & 371.5 \\
\hline $\begin{array}{c}\text { Net expenditures and loans } \\
\text { (billions of FBu) }\end{array}$ & 407.9 & 551.1 & 619.2 & 703.0 & 752.4 \\
\hline $\begin{array}{c}\text { Overall balance } \\
\text { (commitment basis) } \\
\text { (billions of FBu) }\end{array}$ & -210.4 & -301.3 & -330.6 & -372.7 & -380.9 \\
\hline Soure Esms & & & & 27.1 \\
\hline
\end{tabular}

Source: Estimates and projections by IMF staff

345. The projected data are based on a growth rate of roughly 5 percent per year for the coming years. Inflation may fall to 6.8 percent in 2011, with a peak for the current year (2008). This relatively high level is the consequence of the increase in the price of raw 
materials over several years, largely due to the higher price of oil and basic foodstuffs on the international scale, and in particular in Burundi. It will take several years for Burundi to significantly increase agricultural productivity, and this explains the expected weakness in the amount of its exports which, in the short term, will continue to be predominantly agricultural.

346. By contrast, the reconstruction of the country and meeting the basic needs of the people, financed largely by international assistance, require major imports which should have an influence the trade balance for some time to come. The inclusion of other factors, such as the current transactions balance, results in a very negative current account excluding transfers.

347. Burundi will probably continue to be heavily indebted even after it receives assistance from the enhanced HIPC Initiative and the MDRI. Thus, it is important for Burundi to maintain a conservative budget policy and to make use in particular of grants and loans with highly concessional terms to avoid unsustainable indebtedness.

348. However, official investment assistance and debt forgiveness generate positive capital and financial accounts for the entire projection period. It is important to note that when the completion point is reached in end-2008, debt relief will automatically create major financial repercussions for the capital and financial accounts.

349. The government is emphasizing the paramount importance of mobilizing sufficient domestic revenue to make the budget viable and increase spending on poverty reduction. Government revenue should increase regularly due to streamlined tax levies and the introduction of a value-added tax at the same time that expenditures will rise, in order to finance the ramping up of development and poverty-reducing programs. Consequently, support from Burundi's partners will remain essential to contribute to financing government spending, of about 50 percent, to balance its budget.

350. Along these same lines, the government will place high priority on improving the composition of spending. The public sector wage bill, which amounted to 10.8 percent of GDP in 2007, is lower than the average of 12.1 percent for the countries of Sub-Saharan Africa. However, to avoid further risks for the budget, the government will be careful to maintain a viable wage bill. 


\section{PRSP MONITORING-EVALUATION SYSTEMS}

\subsection{The Institutional Monitoring and Evaluation System}

351. The PRSP monitoring and evaluation strategy relies on strengthening the existing monitoring and evaluation systems, updating the monitoring indicators in the priority sectors, and performing annual reviews to prepare the next PRSP. The strategy also includes ongoing and permanent donor involvement to set up a dynamic partnership framework for coordinating improved assistance.

\section{The ownership issue}

352. Ownership of the PRSP first assumes a good knowledge of the basic document, its content, its scope, and its purpose, by all of the players in the process. Next, it is based on the full involvement of the stakeholders in the process of preparing for monitoring and evaluation. If the preparation of the SCLP met the participatory consultation requirements, the SCLP monitoring-evaluation process suffered from insufficient involvement of all the players. In the government, the poor capacities in the ministries failed to facilitate a coherent and harmonious link between the sectoral policies and the overall poverty reduction strategy. The private sector did not properly assume and internalize its role as an engine, particularly for implementing axis No. 2 (Promoting sustainable and equitable growth), while civil society, because it is poorly organized, did not play its role of devising proposals.

353. During the evaluation workshops, it was found that the government officials and some deconcentrated entities of the government did not have the PRSP documents. The reports that were prepared during the consultations were not forwarded to the respective users either. The advisory bodies set up to disseminate and monitor PRSP implementation, i.e. the Provincial Development and Poverty Reduction Committees, and the Communal Development and Poverty Reduction Communities, were not operational. Institutional anchoring for them has still not been clarified, and they were diluted into the other community development entities such as the Community Development Committees and Communal Communities for Community Development. For example, out of 129 communes, just two organized Communal Development and Poverty Reduction Committee meetings after the preparatory PRSP consultations in 2004 and 2005. The other communes seem to have completely ignored this strategic framework and they claim that the problem is the insufficient effort made to disseminate it.

354. To give legitimacy to these committees, an operations guide should be prepared and their relations with the government, the technical entities and the other community organizations should be clarified. To avoid overlapping among the different existing community organizations, merging all the development committees into one should be proposed, as leader and catalyst for all the development programs. The sectoral and thematic committees which operate in the central government should also be restructured to better meet the requirements of effectively coordinating the strategies that are the priority areas of the PRSP. 


\section{Development partners' forum}

355. In implementing the PRSP, in May 2007 the government organized a roundtable for donors. This forum gave Burundi the opportunity to introduce to its partners the priorities in the PRSP and the support expected from the international community. This forum confirmed the general consensus around the PRSP and made it a framework of reference for economic and financial cooperation. On this occasion, the donors encouraged the government to create a partner coordination group (PCG) to support the governmental institutions to implement the Strategic Growth and Poverty Reduction Framework. They promised substantial technical and financial support to assist the government in its efforts.

\section{PCG architecture}

356. This joint evaluation body is built around a three-level system: (i) At the base, the first level consists of the sectoral groups that will deal with everything related to preparing and monitoring their sectoral strategies and will lead technical discussions on coordinating program implementation. A PRSP monitoring-evaluation group will provide overall monitoring; the group will consist of the Permanent Secretariat for Monitoring Economic and Social Reforms (REFES), the Permanent Secretariat of the National Assistance Coordinating Committee, and the Vice-Ministry in Charge of Planning; (ii) At the second level, the Strategic Forum of the Partner Coordinating Group will address the key issues that emerge from the sectoral groups in accordance with the PCG mission; (iii) The third level consists of the PCG Policy Forum, which includes the senior policy authorities of the government as well as chiefs of mission from the partner countries and representatives of international organizations.

\section{Donor promises}

357. After the roundtable, the donors made important announcements; 71.4 percent is for development assistance for the projects the PAP is carrying out and 18.6 percent is for budget support. 
Table 36: Donor promises during the roundtable, 2007.

\begin{tabular}{|c|c|c|c|c|c|c|c|c|}
\hline & \multicolumn{3}{|c|}{ Scheduled financing } & \multicolumn{3}{|c|}{ Roundtable promises } & & \\
\hline Partners & $\begin{array}{l}\text { Projects } \\
\text { and } \\
\text { actions } \\
2007- \\
2010 \text { (in } \\
\text { millions } \\
\text { of } \$ \text { ) }\end{array}$ & $\begin{array}{l}2007-2010 \\
\text { budget } \\
\text { support (in } \\
\text { millions of } \\
\$ \text { ) }\end{array}$ & $\mathrm{S} / \mathrm{T} 1$ & $\begin{array}{l}\text { 2007-2010 } \\
\text { PAP- PRSP } \\
\text { financing (in } \\
\text { millions of } \$ \text { ) }\end{array}$ & $\begin{array}{l}2007-2010 \\
\text { budget } \\
\text { support (in } \\
\text { millions of } \\
\$ \text { ) }\end{array}$ & $\mathrm{S} / \mathrm{T} 2$ & $\begin{array}{c}\text { Grand } \\
\text { total }\end{array}$ & $\%$ \\
\hline WB & 176.00 & 55.00 & 231.00 & 145.00 & 110.00 & 255.00 & 486.00 & 30.34 \\
\hline $\begin{array}{c}\text { European } \\
\text { Union }\end{array}$ & 207.40 & 40.00 & 247.40 & & & & 247.40 & 15.44 \\
\hline $\begin{array}{c}\text { The } \\
\text { Netherlands }\end{array}$ & 4.50 & 10.00 & 14.50 & 88.80 & 53.28 & 142.08 & 156.58 & 9.77 \\
\hline Belgium & 94.90 & 2.60 & 97.50 & 0.00 & 5.46 & 5.46 & 102.96 & 6.43 \\
\hline BADEA & & & 0.00 & 72.00 & 0.00 & 72.00 & 72.00 & 4.49 \\
\hline Russia & 14.70 & & 14.70 & 66.00 & 0.00 & 66.00 & 80.70 & 5.04 \\
\hline Germany & 62.00 & & 62.00 & & & & 62.00 & 3.87 \\
\hline Norway & & 10.00 & 10.00 & 30.00 & 20.00 & 50.00 & 60.00 & 3.75 \\
\hline $\mathrm{AfDB} / \mathrm{AfDF}$ & 58.70 & & 58.70 & & & & 58.70 & 3.66 \\
\hline France & 49.80 & 2.70 & 52.50 & 1.90 & 2.70 & 4.60 & 57.10 & 3.56 \\
\hline USA & 7.60 & & 7.60 & 38.50 & 0.00 & 38.50 & 46.10 & 2.88 \\
\hline PBF & 34.20 & & 34.20 & & & & 34.20 & 2.13 \\
\hline Global Fund & 31.00 & & 31.00 & & & & 31.00 & 1.94 \\
\hline Switzerland & 14.70 & 0.00 & 14.70 & 14.50 & 0.00 & 14.50 & 29.20 & 1.82 \\
\hline IFAD & 20.20 & 0.00 & 20.20 & 6.00 & 0.00 & 6.00 & 26.20 & 1.64 \\
\hline UNICEF & 12.40 & & 12.40 & & & & 12.40 & 0.77 \\
\hline China & & & 0.00 & 12.00 & 0.00 & 12.00 & 12.00 & 0.75 \\
\hline Sweden & & & 0.00 & 7.00 & 0.00 & 7.00 & 7.00 & 0.44 \\
\hline UNDP & 4.90 & & 4.90 & & & & 4.90 & 0.31 \\
\hline Japan & 4.00 & & 4.00 & & & & 4.00 & 0.25 \\
\hline Geneva Global & & & 0.00 & 3.50 & 0.00 & 3.50 & 3.50 & 0.22 \\
\hline GLIA & & & 0.00 & 3.00 & 0.00 & 3.00 & 3.00 & 0.19 \\
\hline UNFPA & 2.40 & & 2.40 & & & & 2.40 & 0.15 \\
\hline Luxembourg & & & 0.00 & 1.30 & 0.00 & 1.30 & 1.30 & 0.08 \\
\hline $\mathrm{ACBF}$ & 1.00 & 0.00 & 1.00 & 0.00 & 0.00 & 0.00 & 1.00 & 0.06 \\
\hline ECCAS & & & 0.00 & 0.20 & 0.00 & 0.20 & 0.20 & 0.012 \\
\hline Morocco & & & 0.00 & 0.10 & 0.00 & 0.10 & 0.10 & 0.006 \\
\hline $\begin{array}{c}\text { Total } \\
\text { Financing }\end{array}$ & 800.40 & 120.30 & 920.70 & 489.80 & 191.44 & 681.24 & 1601.94 & 100.00 \\
\hline
\end{tabular}

Source: Roundtable report, May 2007

358. As of end-2007, about 30 percent of the funds promised had in fact been disbursed. Once the partnership that will gradually become operational in all the priority sectors identified by the PRSP has been strengthened, and once the associated committees have been strengthened, performances will improve, both in coordinating assistance and in implementing programs. 


\subsection{Statistics system}

359. The ISTEEBU set up a PRSP monitoring-evaluation system that proposes to increase the capacities of the national and sectoral statistics systems. It should ensure that relevant results indicators are produced that can be accessed promptly. The first component of this system consists of programs to strengthen the ISTEEBU statistical production system so that it is able to provide monitoring and evaluation indicators for the PRSP development programs. The second component of this system is support for the statistical production sectoral organizations that are outside the ISTEEBU, so that they improve the quality of the statistics for which they are responsible. In this process, the ongoing concern is to be able to provide statistical information on the effectiveness and impact of the different government policies, reforms and programs in terms of jumpstarting the economic sector, reducing poverty, and improving the people's living conditions.

Strengthening the national statistics system

360. As of end-2007, the ISTEEBU already achieved a certain number of results, the most noteworthy of which are reviewed in the following paragraphs.

\section{Institution-building}

361. When Burundi joined AFRISTAT in late-2006, and with the enactment of the Statistics Act in September 2007, these two events will have been the culmination of the efforts to improve institutional and technical coordination in the statistics system. Efforts to strengthen the system for producing quality statistical data are currently concentrating on preparing a National Statistics Development Strategy, to include a National Action Plan as well as a realistic timeline for implementing the programs that have been adopted and budgeted.

362. To facilitate identifying the strengths and weaknesses of the statistics system, an assessment of the entire statistics system in Burundi will first be performed. In the medium term, Burundi should join the IMF's GDDS, in which 84 countries already participate. In the context of this participation, Burundi will disseminate its current statistical practices (metadata) and the projects to develop its national statistics system in the IMF dissemination standards display table.

\section{Revitalizing statistical production}

363. Efforts are centered on providing reliable statistics so that results-based management can be implemented as proposed in The Paris Declaration on the Effectiveness of Development Assistance. Improving data quality and reliability requires the periodic publication of official documents. These documents create the conditions for a gradual improvement in expertise and for a genuine debate on the methods of calculating the statistical indicators that are produced. 


\section{Standard publications}

364. Statistical production has been revitalized, so that there are no more delays in the standard publications by the ISTEEBU. These are primarily:

- The Consumer Price Index for the households of Bujumbura

- The Monthly Price Report, published at the end of each month

- The 2006 Statistical Yearbook, which was just published, and the 2007 book, now being finalized.

365. New publications on monitoring-evaluation were planned for the end of 2007. They are the 2006 Agricultural Yearbook and the 2006 Foreign Trade Statistics Yearbook.

\section{Ad hoc publications}

366. In 2007 the ISTEEBU implemented and published the results of a series of ad hoc surveys with donor support. The most important are:

i. The 1-2-3 Survey (on the employment sector, the informal sector and consumer spending) in Bujumbura, Gitega, Makamba and Kirundo.

ii. The MICS 3 Survey, which was finalized with the analysis of its results and confirmed by UNICEF Headquarters for its good quality, so that today they can be disseminated.

iii. The General Census of Coffee Growers, with OCIBU funding.

iv. The Market Profiles Survey with WFP funding.

v. The Socioeconomic Survey of Urban Transport in Bujumbura, with funding from Japanese Development Cooperation, with results that were used to prepare projects and programs to improve transport in Bujumbura.

vi. The National Nutritional Surveillance Survey, with UNICEF and WFP financing.

vii. The 2007 Priority-Panel Survey.

Before the end of 2008 there are plans to supplement these activities to meet the urgent needs of poverty monitoring, PRSP evaluation and macroeconomic management. Thus, the price statements have retained the same intensity and coverage even though the PCIBurundi program has ended. Moreover, the ISTEEBU is a member of the Central Census Office and is closely monitoring preparations for this highly strategic activity for the national statistics system.

\subsection{Performance indicators}

367. The indicators that were identified demonstrate the early trends and thus identify the sectors in which there has been significant progress, as well as others in which, by contrast, the situation is stagnant or deteriorating. The summary information that the indicator matrix provides is that the results of the first year of PRSP implementation are encouraging overall. Analyzing the results by strategic axis, the situation is as follows:

368. For the first strategic axis, "Improving governance and security," the indicators on justice suggest that much work remains to be done. The percentage of judgments handed down relative to the number of cases on the docket must be increased, the percentage of judgments executed relative to the number of judgments handed down must 
be increased, and the percentage of criminal cases closed must increase compared to the number of criminal cases opened. The same is true for accelerating the construction of low-level courts to facilitate the people's access to justice services. Data on demobilization and reintegration, and on the professionalization of the defense and security corps, also indicate that progress has been made, but that continuation is merited.

369. For the second strategic axis, "Promoting sustainable and fair growth," the trend is somewhat mixed. GDP growth was well below projections, while international economic conditions had a negative impact on development activities, mainly because of the surge in the price of petroleum products.

370. By contrast, the third strategic axis, "Developing human capital," is characterized by noteworthy progress. The indicators on the numbers of assisted vulnerable persons, appropriations for housing, the completion rate for primary schools, assisted deliveries, and the vaccine coverage rate have evolved positively. The adult literacy rate, the health facility usage index and the enrollment rate for girls in primary schools improved as well.

371. Finally, the fourth strategic axis, "The fight against HIV/AIDS," performed well, especially in terms of the number of care providers trained in antiretroviral treatment and treatment for disadvantaged PLWHA and affected persons who received support through IGAs. 
Table 37: Determinants of poverty in Burundi

\begin{tabular}{|c|c|c|c|c|c|c|c|c|c|}
\hline & \multicolumn{3}{|c|}{ OLS } & \multicolumn{3}{|c|}{ PROBIT } & \multicolumn{3}{|c|}{ PROBIT } \\
\hline & \multicolumn{3}{|c|}{ Log daily expenditure by adult equiv. (in Fbu) } & \multicolumn{3}{|c|}{ Equal 1 if poor and 0 otherwise } & \multicolumn{3}{|c|}{ Equal 1 if poor and 0 otherwise } \\
\hline & $\begin{array}{l}\text { National } \\
\text { Coef. }\end{array}$ & $\begin{array}{l}\text { Urban } \\
\text { Coef. }\end{array}$ & $\begin{array}{l}\text { Rural } \\
\text { Coef. }\end{array}$ & $\begin{array}{l}\text { National } \\
\mathrm{dF} / \mathrm{dX}\end{array}$ & $\begin{array}{l}\text { Urban } \\
\qquad \mathrm{dF} / \mathrm{dX}\end{array}$ & $\begin{array}{l}\text { Rural } \\
\qquad \mathrm{dF} / \mathrm{dX}\end{array}$ & $\begin{array}{c}\text { National } \\
\mathrm{dF} / \mathrm{dX}\end{array}$ & $\begin{array}{l}\text { Urban } \\
\quad \mathrm{dF} / \mathrm{dX}\end{array}$ & $\begin{array}{l}\text { Rural } \\
\qquad \mathrm{dF} / \mathrm{dX}\end{array}$ \\
\hline \multicolumn{10}{|l|}{ Place of residence } \\
\hline Urban & $0.108^{* * *}$ & - & - & $-0.094 * *$ & - & - & $-0.087 * *$ & - & - \\
\hline Rural & Ref. & - & - & Ref. & - & - & Ref. & - & - \\
\hline \multicolumn{10}{|l|}{ Province } \\
\hline Bubanza & -0.006 & - & -0.015 & -0.034 & - & -0.041 & -0.068 & - & 0.003 \\
\hline Bujumbura Mairie & Ref. & Ref. & - & Ref. & Ref. & - & Ref. & Ref. & - \\
\hline Bujumbura Rural & 0.007 & - & Ref. & 0.014 & - & Ref. & -0.072 & - & Ref. \\
\hline Bururi & -0.054 & -0.025 & -0.047 & 0.028 & 0.048 & 0.007 & $-0.122 * *$ & -0.052 & -0.051 \\
\hline Cankuzo & $-0.240^{* * *}$ & - & $-0.238^{* * *}$ & $0.176^{* * *}$ & - & $0.156^{* * *}$ & $0.171^{* * *}$ & - & $0.198 * * *$ \\
\hline Cibitoke & -0.080 & - & $-0.085 * * *$ & 0.061 & - & 0.049 & -0.065 & - & 0.004 \\
\hline Gitega & $-0.171 * * *$ & $-0.198 * * *$ & $-0.181 * * *$ & $0.168^{* * *}$ & $0.285^{* * *}$ & $0.147 * * *$ & $-0.109 * *$ & $-0.196 * * *$ & -0.021 \\
\hline Karuzi & $-0.218^{* * *}$ & - & $-0.218^{* * *}$ & $0.190^{* * * *}$ & - & $0.171^{* * *}$ & -0.078 & - & -0.007 \\
\hline Kayanza & $-0.262 * * *$ & - & $-0.273^{* * *}$ & $0.204^{* * * *}$ & - & $0.187^{* * *}$ & $-0.125^{* *}$ & - & -0.046 \\
\hline Kirundo & $-0.366^{* * *}$ & - & $-0.377 * * *$ & $0.296^{* * *}$ & - & $0.273 * * *$ & 0.077 & - & $0.127 * * *$ \\
\hline Makamba & -0.021 & - & -0.025 & 0.016 & - & 0.002 & $-0.191 * * *$ & - & $-0.113 * * *$ \\
\hline Muramvya & $-0.188 * * *$ & - & $-0.188 * * *$ & $0.141^{* *}$ & - & $0.125^{* * *}$ & $-0.090 *$ & - & -0.018 \\
\hline Muyinga & $-0.224^{* * *}$ & - & $-0.226^{* * *}$ & $0.175^{* * *}$ & - & $0.155^{* * *}$ & -0.052 & - & 0.018 \\
\hline Mwaro & $-0.170^{* * *}$ & - & $-0.167 * * *$ & $0.106^{*}$ & - & $0.089^{* *}$ & $-0.125^{* *}$ & - & -0.051 \\
\hline Ngozi & $-0.376^{* * *}$ & $-0.422 * * *$ & $-0.382^{* * *}$ & $0.269^{* * *}$ & $0.319^{* * *}$ & $0.253^{* * *}$ & $-0.108^{* *}$ & -0.034 & -0.050 \\
\hline Rutana & $-0.193 * * *$ & - & $-0.197 * * *$ & $0.166^{* * *}$ & - & $0.146^{* * *}$ & $-0.101^{*}$ & - & -0.028 \\
\hline Ruyigi & $-0.276^{* * *}$ & - & $-0.280^{* * *}$ & $0.223 * * *$ & - & $0.202 * * *$ & -0.026 & - & 0.038 \\
\hline \multicolumn{10}{|l|}{ Household Composition } \\
\hline Number of children ( 0 to 5 years) & $-0.126^{* * *}$ & $-0.154^{* * *}$ & $-0.122 * * *$ & $0.124^{* * *}$ & 0.065 & $0.127 * * *$ & $-0.037 * *$ & -0.085 & $-0.031 *$ \\
\hline Number of children squared & $0.013^{* *}$ & 0.021 & $0.012 * *$ & -0.010 & -0.003 & -0.009 & 0.008 & 0.023 & 0.006 \\
\hline Number of teens ( 6 to 14 years) & $-0.244^{* * *}$ & $-0.231 * * *$ & $-0.246^{* * *}$ & $0.246 * * *$ & $0.193^{* * *}$ & $0.238 * * *$ & 0.015 & 0.041 & 0.010 \\
\hline Number of teens squared & $0.027 * * *$ & $0.026^{* * *}$ & $0.027 * * *$ & $-0.030 * * *$ & $-0.028 * * *$ & $-0.027 * * *$ & $-0.005^{*}$ & -0.010 & -0.005 \\
\hline Number of adults ( 15 to 59 years) & $-0.212 * * *$ & $-0.122 * * *$ & $-0.224 * * *$ & $0.195^{* * *}$ & $0.152 * * *$ & $0.175^{* * *}$ & $-0.054 * * *$ & $-0.090^{* *}$ & $-0.045^{* * *}$ \\
\hline Number of adults squared & $0.016^{* * *}$ & $0.008^{* *}$ & $0.016^{* * *}$ & $-0.015^{* * *}$ & $-0.016^{* * *}$ & $-0.010^{* * *}$ & 0.002 & 0.006 & 0.002 \\
\hline Number of seniors (60 years and above) & -0.019 & 0.011 & -0.027 & 0.020 & 0.008 & 0.028 & $-0.053^{* * *}$ & $-0.082 *$ & $-0.039^{*}$ \\
\hline
\end{tabular}




\begin{tabular}{|c|c|c|c|c|c|c|c|c|c|}
\hline \multirow[b]{2}{*}{ Number of seniors squared } & \multicolumn{3}{|c|}{ OLS } & \multicolumn{3}{|c|}{ PROBIT } & \multicolumn{3}{|c|}{ PROBIT } \\
\hline & $0.009^{* * *}$ & 0.008 & 0.007 & -0.003 & -0.002 & -0.004 & $0.008^{* *}$ & $0.014^{*}$ & 0.006 \\
\hline Age of the head of household & $0.006^{* * *}$ & 0.013 & $0.006^{* *}$ & -0.004 & -0.002 & $-0.005^{*}$ & $-0.006 * *$ & -0.009 & $-0.006^{* *}$ \\
\hline Age of head of household squared & $-0.000 * * *$ & $-0.000^{*}$ & $-0.000 * * *$ & $0.000^{* *}$ & 0.000 & $0.000 * * *$ & $0.000 * *$ & 0.000 & $0.000^{* *}$ \\
\hline Female Head of Household & $-0.054 * * *$ & -0.071 & $-0.052 * * *$ & $0.039^{* *}$ & 0.036 & $0.034 *$ & $0.151^{* * *}$ & 0.083 & $0.161 * * *$ \\
\hline Handicapped Head of household & $-0.101^{* * *}$ & $-0.140^{*}$ & $-0.089 * * *$ & $0.072 * *$ & 0.023 & $0.069 * *$ & $0.080^{* * *}$ & 0.143 & $0.071 * * *$ \\
\hline (War-) Displaced Head of household & $-0.036^{* * *}$ & $-0.156^{* * *}$ & -0.015 & 0.019 & $0.072 *$ & 0.007 & $0.086^{* * *}$ & $0.092 * *$ & $0.081 * * *$ \\
\hline \multicolumn{10}{|l|}{ Education of Head of household } \\
\hline No education & Ref. & Ref. & Ref. & Ref. & Ref. & Ref. & Ref. & Ref. & Ref. \\
\hline Primary & $0.100^{* * *}$ & $0.256^{* * *}$ & $0.082 * * *$ & $-0.106^{* * *}$ & $-0.171 * * *$ & $-0.092 * * *$ & $-0.099 * * *$ & $-0.129^{* *}$ & $-0.091 * * *$ \\
\hline Secondary & $0.449 * * *$ & $0.424 * * *$ & $0.446^{* * *}$ & $-0.342 * * *$ & $-0.218 * * *$ & $-0.375 * * *$ & $-0.264 * * *$ & $-0.238^{* * *}$ & $-0.263 * * *$ \\
\hline Superior & $0.788 * * *$ & $0.666^{* * *}$ & $0.470^{* *}$ & $-0.544 * * *$ & & $-0.398 * *$ & $-0.328 * * *$ & $-0.315^{* * *}$ & -0.092 \\
\hline \multicolumn{10}{|l|}{ Socioeconomic Group of Head of household } \\
\hline Owner & 0.032 & 0.067 & -0.011 & -0.050 & 0.016 & -0.047 & 0.045 & -0.158 & 0.109 \\
\hline Permanent employee & Ref. & Ref. & Ref. & Ref. & Ref. & Ref. & & & \\
\hline Non permanent employee & $-0.277 * * *$ & $-0.350 * * *$ & $-0.248 * * *$ & $0.259 * * *$ & $0.362 * * *$ & $0.221 * * *$ & $0.167 * * *$ & $0.198 * * *$ & $0.173 * * *$ \\
\hline Independent worker & $-0.078 * *$ & -0.046 & $-0.087 * *$ & $0.086^{*}$ & $0.228 * *$ & 0.051 & 0.026 & $-0.137 *$ & $0.069^{*}$ \\
\hline Apprentice/intern & $-0.203 * * *$ & $-0.410^{* * *}$ & $-0.162 * * *$ & $0.152 * * *$ & $0.267^{*}$ & $0.114 * *$ & $0.225^{* * *}$ & 0.165 & $0.226 * * *$ \\
\hline Other & $-0.212 * * *$ & $-0.204 * * *$ & $-0.192 * * *$ & $0.219^{* * *}$ & $0.255^{* * *}$ & $0.188 * * *$ & $0.141^{* * *}$ & 0.101 & $0.158 * * *$ \\
\hline Land Ownership & 0.002 & -0.032 & 0.026 & -0.034 & -0.021 & $-0.045^{*}$ & -0.010 & -0.007 & -0.015 \\
\hline \multicolumn{10}{|l|}{ Access to Infrastructure (time in 1000 minutes) } \\
\hline Source of drinking water & $-0.989 * * *$ & -1.610 & $-0.682 * *$ & $1.230^{* * *}$ & 0.323 & $1.091 * * *$ & 0.376 & 1.660 & 0.257 \\
\hline Market of food products & -0.011 & -0.475 & 0.029 & 0.019 & 0.994 & -0.058 & $0.392 * *$ & 0.521 & $0.398^{* *}$ \\
\hline Public Transport & $-0.263 * * *$ & -0.263 & $-0.281 * * *$ & 0.096 & -0.411 & 0.112 & -0.125 & 0.649 & -0.115 \\
\hline Road functioning in all seasons & $-0.306^{* *}$ & $-3.908 * *$ & $-0.326^{* *}$ & 0.181 & 1.625 & 0.202 & $0.618^{* * *}$ & 2.387 & $0.578 * * *$ \\
\hline Primary school & $-0.647 * *$ & 0.671 & $-0.605^{* *}$ & 0.402 & 2.106 & 0.219 & 0.471 & 1.618 & 0.326 \\
\hline Secondary school & $-0.290^{* *}$ & -1.141 & $-0.337^{* *}$ & $0.481 * *$ & 0.320 & $0.529 * * *$ & 0.145 & -1.492 & 0.185 \\
\hline Hospital & -0.037 & $-1.029 * *$ & 0.002 & 0.130 & $1.180^{* *}$ & 0.085 & -0.015 & $1.067^{*}$ & -0.049 \\
\hline Health center (beside hospital) & -0.013 & $-2.234^{* *}$ & 0.041 & 0.006 & -0.034 & 0.012 & -0.045 & 0.044 & -0.063 \\
\hline Office of the head of the colline/neighborhood & $-0.504 *$ & -0.834 & -0.349 & $0.605^{*}$ & 1.691 & 0.456 & $1.459^{* * *}$ & -0.579 & $1.490 * * *$ \\
\hline Constant term & $1.094 * * *$ & $1.075^{* * *}$ & $1.057 * * *$ & & & & & & \\
\hline Observations & 7020 & 802 & 6218 & 7020 & 721 & 6218 & 7020 & 802 & 6218 \\
\hline R-squared & 0.47 & 0.53 & 0.42 & & & & & & \\
\hline
\end{tabular}

Source : World Bank estimates based on 2006 CWIQ survey

Note. ${ }^{*}$ significatif au seuil de $10 \%$; ${ }^{* *}$ significatif au seuil de $5 \%$; *** significatif au seuil de $1 \%$. 
Table 38: Determinants for demand for education

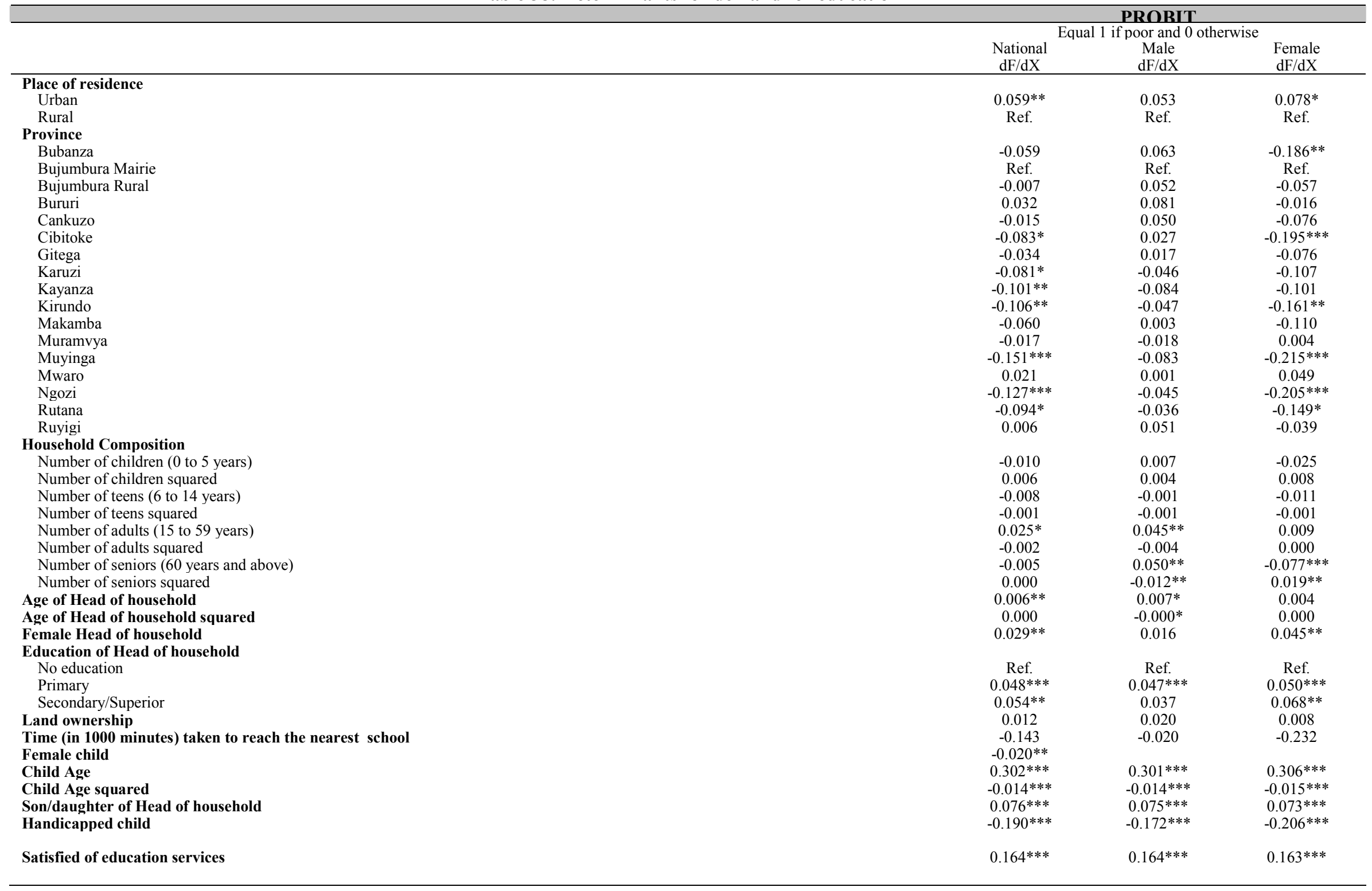


Mean Schooling of Children aged 7-14 years old

Reasons for the non-schooling of children aged 7-14 years old

Very young
Very old

Completed schooling

Lives very far

Very expensive

Works (home/any job)

No interest/schooling is useless

Sick

Failed exam

Pregnancy

Welfare Quintile

\begin{tabular}{ll} 
& $\mathrm{Q} 1$ \\
$\mathrm{Q} 2$ & $\mathrm{Q} 3$ \\
$\mathrm{Q}$ & $\mathrm{Q}$ \\
\hline
\end{tabular}

Observations

Source : World Bank estimates based on 2006 CWIQ survey.

Note : * significant at $10 \%$; ** significant at $5 \% ; * * *$ significant at $1 \%$

\begin{tabular}{ccc}
$0.357^{* * *}$ & $0.532^{* * *}$ & $0.199^{*}$ \\
-0.002 & -0.003 & -0.001 \\
$-0.002^{*}$ & -0.001 & $-0.004 * *$ \\
$0.004^{*}$ & 0.004 & 0.004 \\
-0.008 & 0.002 & $-0.016^{*}$ \\
$-0.004^{* * *}$ & $-0.006^{* * *}$ & -0.003 \\
-0.002 & -0.001 & -0.002 \\
-0.002 & -0.002 & -0.001 \\
-0.004 & 0.001 & -0.008 \\
0.004 & 0.000 & $0.008^{* *}$ \\
0.004 & 0.026 & -0.016 \\
& & \\
Ref. & Ref. & Ref. \\
$0.047^{* * *}$ & $0.051^{* * *}$ & $0.039^{* *}$ \\
$0.072^{* * *}$ & $0.065^{* * *}$ & $0.080^{* * *}$ \\
$0.085^{* * *}$ & $0.076^{* * *}$ & $0.088^{* * *}$ \\
$0.057^{* * *}$ & $0.092^{* * *}$ & 0.020 \\
\hline 7049 & 3526 & 3523
\end{tabular}


Table 39: Performance indicators matrix

\begin{tabular}{|c|c|c|c|c|c|c|}
\hline Strategic AXIS & Indicator & 2006 & 2007 & 2008 & 2009 & 2010 \\
\hline \multicolumn{7}{|l|}{ AXIS 1 IMPROVE GOVERNANCE AND SECURITY } \\
\hline \multicolumn{7}{|l|}{ 1. Strengthen peace, national reconciliation and security } \\
\hline \multicolumn{7}{|l|}{ 1.1.1 Negotiate the cease-fire } \\
\hline \multirow{3}{*}{$\begin{array}{l}\text { 1.1.2 Demobilize, disarm and } \\
\text { Reintegrate }\end{array}$} & Cumulative number of demobilized adults & 19,891 & 20,330 & & & 55,000 \\
\hline & Number of weapons returned or seized & & 7,299 & & & 100,000 \\
\hline & $\begin{array}{l}\text { Number of demobilized persons taking part in support } \\
\text { programs }\end{array}$ & & 12,680 & & & \\
\hline \multirow[t]{2}{*}{ 1.1.3 Professionalize the defense and security corps } & Number of corps members trained & & & & & \\
\hline & Cases of torture & 508 & 429 & & & \\
\hline \multicolumn{7}{|c|}{ 2. Promote the rule of law, action to combat impunity and justice for all } \\
\hline 1.2.1. Facilitate access to justice & Average distance to the court $(\mathrm{km})$ & 26 & 26 & & & 13 \\
\hline 1.2.2 Strengthen the credibility of the judicial system & $\begin{array}{l}\text { Percentage of criminal cases closed compared to the } \\
\text { number of cases opened }\end{array}$ & 97.1 & 99.7 & & & 100 \\
\hline 1.2.3 Promote and defend the rights of the human person & $\begin{array}{l}\text { Percentage of judgments executed compared to the } \\
\text { number of cases tried }\end{array}$ & 61.8 & 37.9 & & & 100 \\
\hline \multicolumn{7}{|c|}{ 3. Reduce the risks of conflict due to land tenure/sustainable management of land tenure conflicts } \\
\hline 1.3.1 Include the land dimension in conflict management & Cumulative number of land conflicts settled by the CNTB & & 278 & & & 8,325 \\
\hline 1.3.2 More fairness in asset management & $\begin{array}{l}\text { Number of programs or awareness workshops in the } \\
\text { communes }\end{array}$ & & & & & \\
\hline \multicolumn{7}{|l|}{ 4. Promote good governance } \\
\hline \multicolumn{7}{|l|}{ Political governance } \\
\hline 1.4.1 Strengthen the capacities of the elected institutions & $\begin{array}{l}\text { Number of local elected officials that have been through at } \\
\text { least one training session }\end{array}$ & 173 & & & & 3,200 \\
\hline $\begin{array}{l}\text { 1.4.2 Promote decentralization and strengthen citizen } \\
\text { Participation }\end{array}$ & $\begin{array}{l}\text { Number of communes that have a validated development } \\
\text { plan }\end{array}$ & 34 & 38 & & & 129 \\
\hline \multirow{2}{*}{$\begin{array}{l}\text { 1.4.3 Strengthen the accountability requirement for government } \\
\text { and elected officials }\end{array}$} & Number of awareness meetings held & & & & & \\
\hline & Number of participants in these meetings & & & & & \\
\hline 1.4.4 Adapt the electoral systems to the socio-political changes & $\begin{array}{l}\text { Number of new laws on this subject enacted by } \\
\text { Parliament }\end{array}$ & & & & & \\
\hline \multicolumn{7}{|l|}{ Administrative governance } \\
\hline 1.4.5 Strengthen the organizational capacities of government & Number of studies validated on government operations & & & & & \\
\hline
\end{tabular}




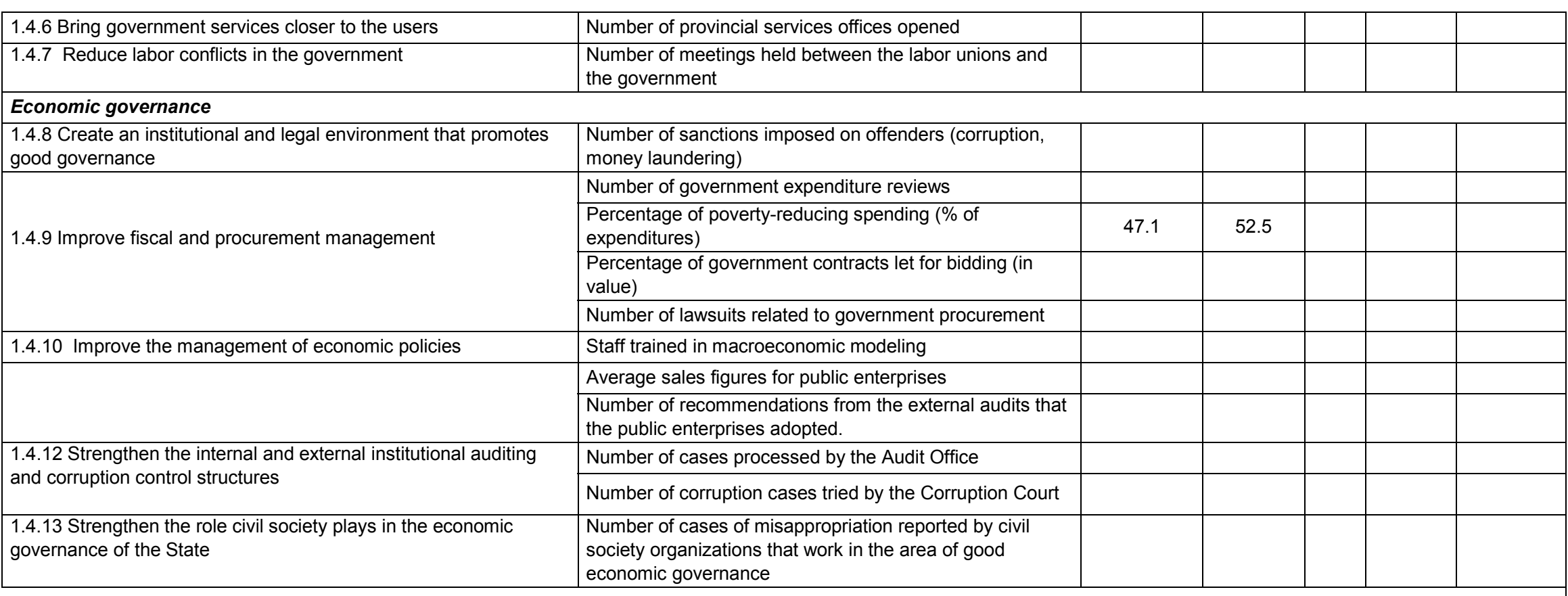

\section{AXE 2 PROMOTE SUSTAINABLE AND EQUITABLE ECONOMIC GROWTH}

\section{Develop growth sectors}

\section{Revitalize agriculture, animal production, fishing and fish farming}

\begin{tabular}{|c|c|c|c|c|}
\hline \multirow{2}{*}{ 2.1.1 Revitalize food crops } & Total grain output (in thousands of metric tons) & 282 & 290 & \\
\hline & Food crop output/inhabitant (in thousands of metric tons) & 0.45 & 0.47 & \\
\hline \multirow{4}{*}{ 2.1.2 Revitalize export crops } & Coffee (exports in metric tons) & 21,410 & 18,560 & \\
\hline & Cotton (exports in metric tons) & 1,170 & 1,100 & \\
\hline & Tea (exports in metric tons) & 5,950 & 6,470 & \\
\hline & Nontraditional crops (in metric tons) & 250 & 530 & \\
\hline \multirow{2}{*}{ 2.1.3 Develop animal production } & Number of bovines (units) & 433,800 & 479,106 & $1,087,352$ \\
\hline & Number of caprines and ovines (units) & $1,705,233$ & $1,899,633$ & $5,018,950$ \\
\hline $\begin{array}{l}\text { 2.1.4 Develop 'beekeeping, fishing and revitalize } \\
\text { fish farming }\end{array}$ & Fish caught (metric tons) & 14,144 & 11,535 & 18,000 \\
\hline
\end{tabular}




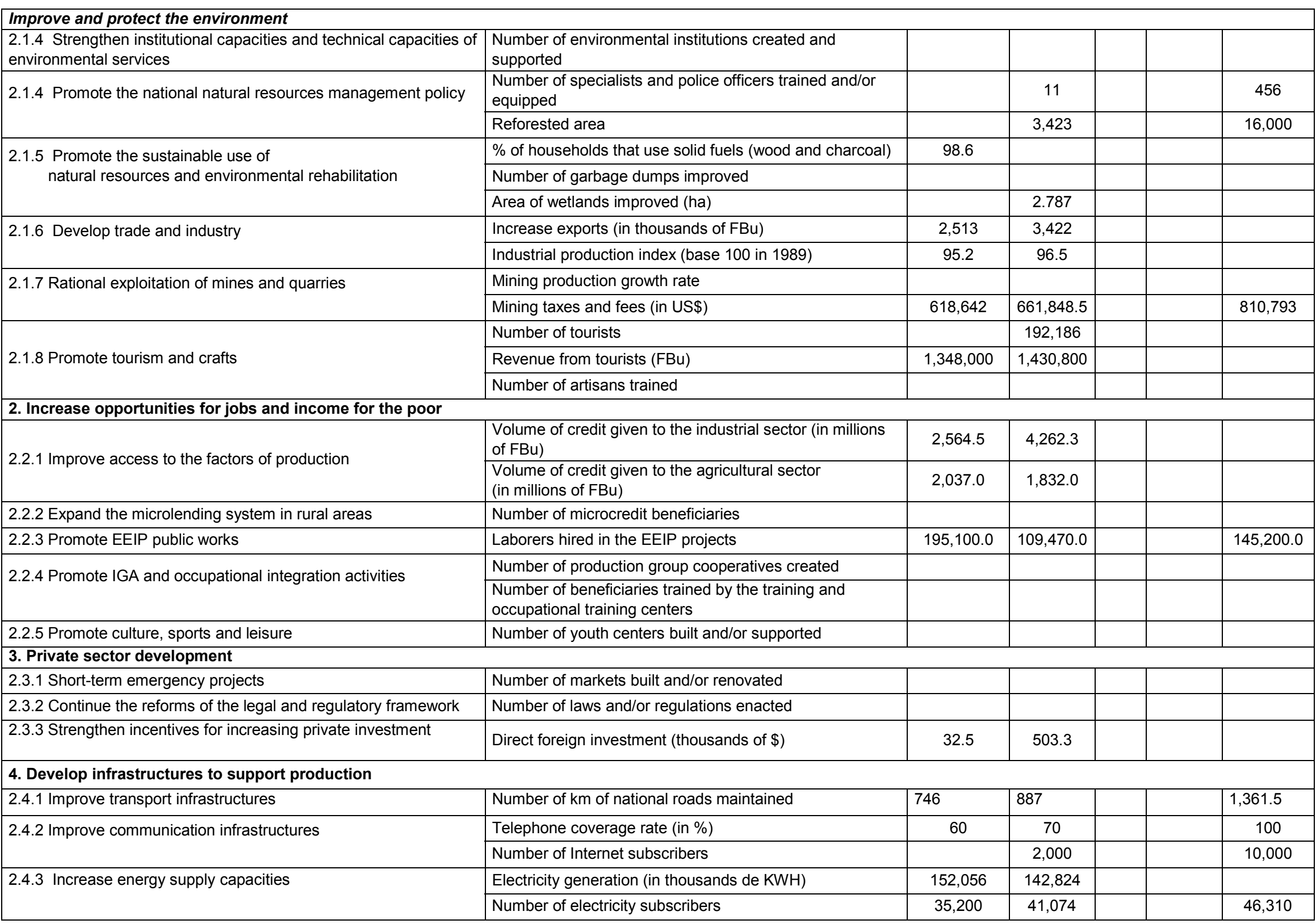




\begin{tabular}{|c|c|c|c|c|}
\hline \multicolumn{5}{|l|}{ AXIS 3 DEVELOPMENT OF HUMAN CAPITAL } \\
\hline \multicolumn{5}{|l|}{ 1. Improve accessibility to and the quality of basic social services } \\
\hline \multicolumn{5}{|l|}{ Education } \\
\hline \multirow{2}{*}{ 3.1.1 Strengthen support and supervision for schools } & Number of trainers trained & & & \\
\hline & Equip with books (FBu) & & & \\
\hline $\begin{array}{l}\text { 3.1.2 Improve accessibility and the quality of learning for young } \\
\text { children }\end{array}$ & Number of nursery schools & & & \\
\hline \multirow{5}{*}{$\begin{array}{l}\text { 3.1.3 Improve accessibility and the quality of learning for primary } \\
\text { education }\end{array}$} & Net admission rate for the first year of primary school & 44 & 51 & 100 \\
\hline & Net primary enrollment rate & 71 & 77.9 & 100 \\
\hline & Teacher qualification rate & 88.7 & 89.5 & 95 \\
\hline & Schoolchildren per teacher & 55 & 54 & 50 \\
\hline & Schoolchildren per class & 86 & 85 & 50 \\
\hline \multirow{2}{*}{$\begin{array}{l}\text { 3.1.4 Improve accessibility and the quality of learning for } \\
\text { secondary education }\end{array}$} & Admission rate for the first year of secondary school & 29.5 & & \\
\hline & $\begin{array}{l}\text { Net enrollment rate for boys in primary school } \\
\text { Boys } \\
\text { Girls }\end{array}$ & $\begin{array}{l}73.2 \\
73.6\end{array}$ & $\begin{array}{l}80.1 \\
78.8\end{array}$ & \\
\hline $\begin{array}{l}3.1 .5 \text { Improve access to and the quality of learning for higher } \\
\text { education }\end{array}$ & Number of theaters built & 12 & & \\
\hline \multicolumn{5}{|l|}{ Health } \\
\hline 3.1.6 Improve the performance of the national health system & Usage rate & 0.6 & 0.7 & 1 \\
\hline \multirow{3}{*}{$\begin{array}{l}\text { 3.1.7 Reduce the prevalence of } \\
\text { transmissible and non-transmissible diseases }\end{array}$} & $\begin{array}{l}\text { Number of associations that fight transmissible diseases } \\
\text { and non-transmissible diseases }\end{array}$ & & & \\
\hline & that were supported and are operational & & & \\
\hline & Number of laboratories strengthened & & & \\
\hline \multirow{2}{*}{ 3.1.8 Reduce maternal and neonatal mortality } & Maternal mortality per 100,000 births & 615 & & \\
\hline & Number of assisted deliveries & 37 & 41.3 & 60 \\
\hline \multirow{2}{*}{ 3.1.9 Reduce infant mortality } & Infant mortality per 1,000 births & 176 & & \\
\hline & Vaccine coverage rate for children under 5 years old & & & \\
\hline \multicolumn{5}{|c|}{ 2. Improve access to drinking water, hygiene, sanitation and decent housing } \\
\hline \multirow{3}{*}{ 3.2.1 Drinking water, hygiene and sanitation } & Access rate to a source of improved water (\%) & 64.3 & & \\
\hline & Connection rate to the water network in urban areas & 38.4 & & \\
\hline & $\%$ with access to an upgraded sanitation facility & 31.7 & & \\
\hline
\end{tabular}




\begin{tabular}{|c|c|c|c|c|}
\hline \multirow{3}{*}{ 3.2.2 Housing and urbanization } & \multicolumn{2}{|l|}{ Urbanization rate } & \multirow[b]{2}{*}{13.5} & \multirow[b]{3}{*}{9.0} \\
\hline & Appropriations for housing (in billions FBu) & 14.8 & & \\
\hline & Average interest rate on housing loans (medium term) & 17.9 & 17.9 & \\
\hline \multirow{3}{*}{ 3.2.3 Support for vulnerable groups } & Number of repatriated persons that took back their land & & & \\
\hline & $\begin{array}{l}\text { Number of vulnerable persons that received medical } \\
\text { assistance }\end{array}$ & 3,400 & 7,607 & 10,000 \\
\hline & Vulnerable households that received food assistance & 10,000 & 15,000 & 30,000 \\
\hline \multirow{2}{*}{ 3.2.4 Gender advancement } & Proportion of seats held by women in Parliament & 31.7 & 31.7 & \\
\hline & Net enrollment rate for girls in primary school & 73.6 & 78.8 & 100 \\
\hline \multicolumn{5}{|l|}{ AXE 4 THE FIGHT AGAINST HIVIAIDS } \\
\hline \multirow{5}{*}{ 4.1. HIV transmission prevention } & Prevalence rate & 3.5 & 3.5 & 3.6 \\
\hline & Number of persons tested during the year & 150,000 & & 150,000 \\
\hline & $\begin{array}{l}\text { Percentage of HIV+ pregnant women that obtain MTCTP } \\
\text { services }\end{array}$ & & 4.7 & 50 \\
\hline & Number of MTCTP centers & 27 & 34 & \\
\hline & Number of condoms distributed (in thousands) & 11,300 & 12,210 & \\
\hline \multirow{2}{*}{ 4.2 Treat patients infected with HIV } & $\begin{array}{l}\text { Percentage of PLWHA } 12 \text { months after ARV treatment } \\
\text { began }\end{array}$ & 89.5 & 80.4 & 95 \\
\hline & \begin{tabular}{|l|} 
Number of healthcare providers trained in antiretroviral \\
treatment (nurses) \\
\end{tabular} & 415 & 544 & 800 \\
\hline 4.3 Reduce impact on persons affected by HIV & $\begin{array}{l}\text { Number of disadvantaged PLWHA and affected persons } \\
\text { that received support through IGA }\end{array}$ & 4,660 & 5,000 & 8,000 \\
\hline \multirow{2}{*}{ 4.4 Strengthen institutional capacities } & Number of people trained & & & \\
\hline & Number of facilities equipped & & & \\
\hline \multicolumn{5}{|l|}{ 5. STRENGTHEN THE NATIONAL STATISTICS SYSTEM } \\
\hline \multicolumn{5}{|l|}{ 1. Capacity-building } \\
\hline $\begin{array}{l}5.1 .1 \text { Strengthen the legal and institutional framework for statistical } \\
\text { activities }\end{array}$ & Revised laws and regulations implemented & & & \\
\hline $\begin{array}{l}\text { 5.1.2 Strengthen the technical capacities of personnel in the } \\
\text { statistical entities }\end{array}$ & Number of statisticians trained & & & \\
\hline \multicolumn{5}{|l|}{ 5.1.3 Prepare the National Statistics Development Strategy } \\
\hline \multicolumn{5}{|l|}{ 2. Revitalize production } \\
\hline 5.2.1 Strengthen the sectoral systems for producing statistics & Number of statistical publications by the ISTEEBU & 15 & 17 & \\
\hline
\end{tabular}




\begin{tabular}{|c|c|c|c|c|}
\hline \multicolumn{5}{|l|}{ 6. MACROECONOMICS AND BUDGET } \\
\hline & Real GDP growth rate & 5.1 & 3.2 & 5.0 \\
\hline & Average annual inflation rate & 2.7 & 8.3 & 8.2 \\
\hline & $\begin{array}{l}\text { Global balance on a commitment basis as a percentage of } \\
\text { GDP }\end{array}$ & -19.3 & -19.9 & -21.6 \\
\hline & Budget deficit (in billions of $\mathrm{FBu}$ ) & 182.2 & 210.4 & 372.7 \\
\hline & Contribution of exports to GDP & 2.6 & -14.3 & 10.4 \\
\hline & Overall investment rate & & & \\
\hline & Tax pressure rate $($ norm $>$ or $=$ a $17 \%)$ & 18.9 & 18.7 & \\
\hline & Ratio of debt service to export revenue & 54.4 & 60.6 & \\
\hline & Outstanding foreign debt as a $\%$ of GDP & 141.8 & $151.1(p)$ & \\
\hline \multicolumn{5}{|l|}{ 7. POPULATION } \\
\hline & Population growth rate & 2.8 & 2.9 & \\
\hline & Average household size & 5.2 & 5.7 & \\
\hline & Urban population (\%) & 6.3 & & \\
\hline & Rural population (\%) & 93.7 & & \\
\hline & Density & & & \\
\hline & Urban poverty index & 34.0 & & \\
\hline & Rural poverty index & 68.9 & & \\
\hline & National poverty index & 66.9 & & \\
\hline \multicolumn{5}{|l|}{ 8. EMPLOYMENT } \\
\hline & Unemployment rate (ILO) (\%) & 13.5 & 13.9 & \\
\hline & Unemployment rate for men (\%) & 10.8 & 12.8 & \\
\hline & Unemployment rate for women (\%) & 17.8 & 15.2 & \\
\hline & Total underemployment rate $(\%)$ & 63.8 & 52.7 & \\
\hline & Visible underemployment rate (\%) & 16.8 & 14.9 & \\
\hline & Invisible underemployment rate (\%) & 50.7 & 41.6 & \\
\hline & Percentage of jobs in the government & 10.1 & 10.1 & \\
\hline & Percentage of jobs in public enterprises & 5.4 & 7.5 & \\
\hline & Percentage of jobs in the formal private sector & 1.2 & 2.5 & \\
\hline & Percentage of jobs in informal private businesses & 78.8 & 76.3 & \\
\hline & Percentage of jobs in associative enterprises & 4.5 & 3.7 & \\
\hline & Average job seniority (years) & 5.3 & 7.2 & \\
\hline
\end{tabular}

